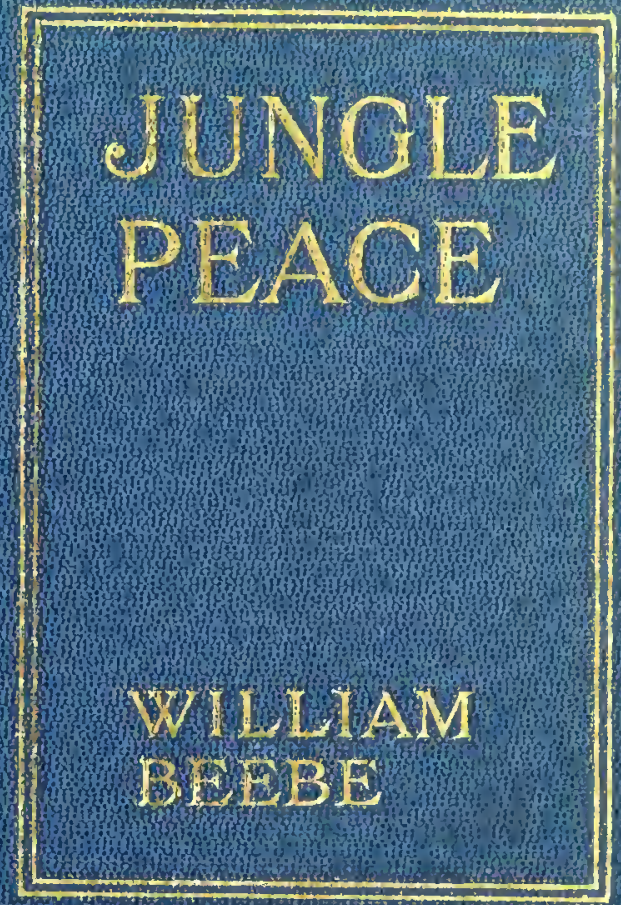


NUNC COGNOSCO EX PARTE

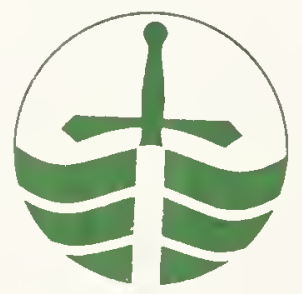

THOMAS J. BATA LIBRARY

TRENT UNIVERSITY 
Digitized by the Internet Archive in 2019 with funding from Kahle/Austin Foundation

https://archive.org/details/junglepeace0000beeb 


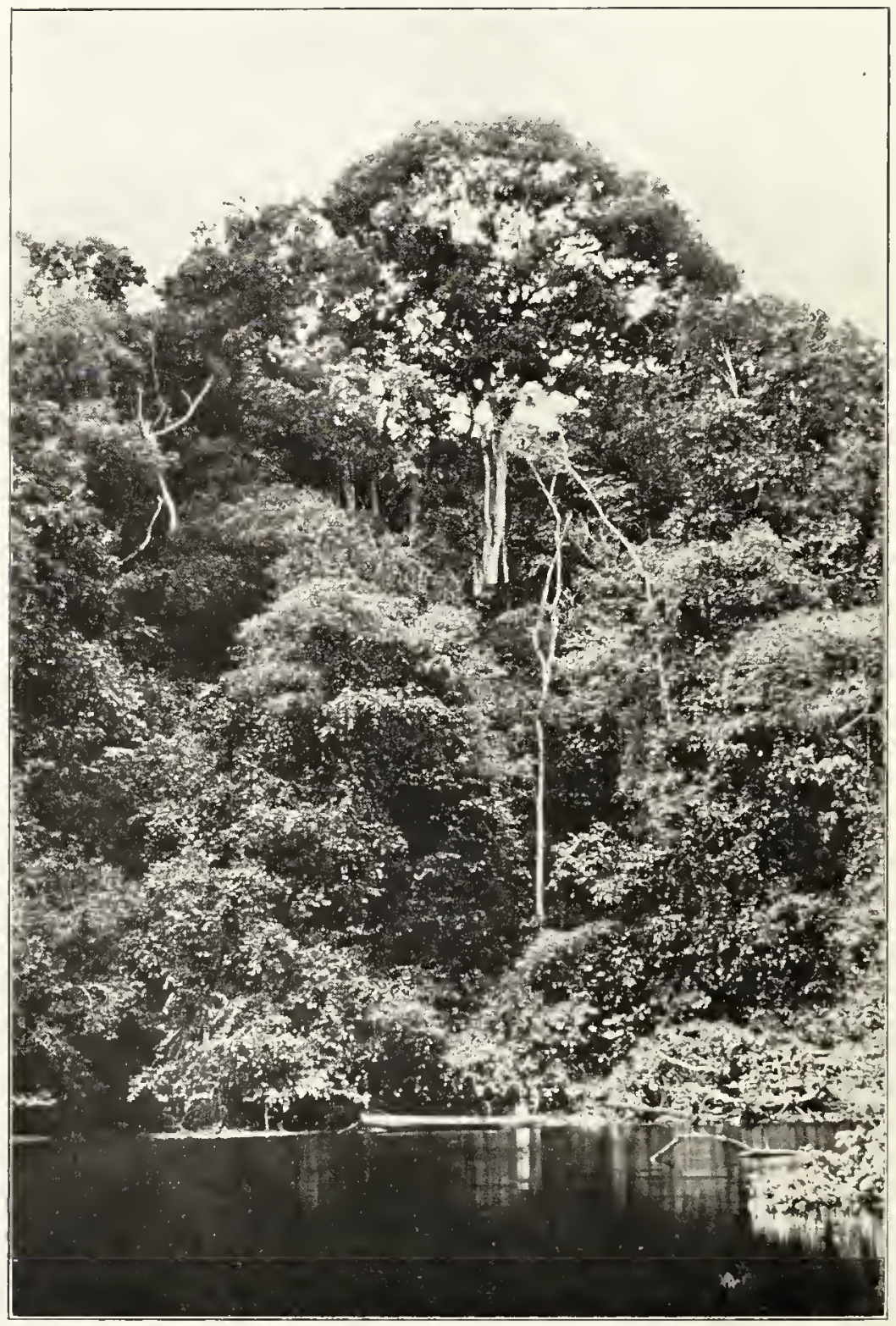

The Peace of the Jungle 


\section{JUNGLE PEACE}

BY

\section{WILLIAM BEEBE}

Carator of Birds, New York Zoological Park, and

Director of Tropical Research Station

\section{ILUUSTRATED FROM PHOTOGRAPHS}

TORONTO

\section{THE COPP CIARK CO. LTD.}

1919 
Copyrient, 1918,

$\mathrm{BY}$

HENRY HOLT AND COMPANY

PRINTED IN THE U. \$. A.

THE OUINM - BODEN CO. PREBS RAMVIAY, N. J. 
TO

COLONEL AND MRS. THEODORE ROOSEVELT I OFFER THIS VOLUME WITH DEEPEST FRIENDSHIP 



\section{NOTE}

With three exceptions these chapters have appeared in the pages of The Allantic Monthly, and I publish them through the kindness of the Editor, Ellery Sedgwick. "Hoatzins at Home" is adapted from a title in my Tropical Wild Life, Volume I, published by the New York Zoological Society, which deals with the more technical results of study at the Research Station. The illustrations are from my own photographs, except the frontispiece and those facing pages 162, 186, and 268, which were taken by Paul G. Howes. All the chapters dealing with the jungle relate to Bartica District, British Guiana, except X, which refers to Pará at the mouth of the Amazon. 



\section{CONTENTS}

CHAPTER

PAGE

I Jünle Peace . . . . . . . 3

II Sea-wrack . . . . . . . . . 5

III Islands . . . . . . . . . . 33

IV The Pomeroon Trail . . . . . 66

V A Hunt for Hoatzins . . . . . 92

VI Hoatzins at Home . . . . . . 123

VII A Wilderness Laboratory . . . . 140

VIII The Convict Trail . . . . . . 177

IX With Army Ants "Somewhere" in the Jungle . • . . • • . . 211

X A Yard of Jungle . . . . . . 239

XI Jungle Night . • • • • • • 263 Index . . . . . . . . . 295 



\section{ILLUSTRATIONS}

PAGE

The Peace of the Jungle . . . Frontispiece Where the Sargasso Floats . . . . . 16

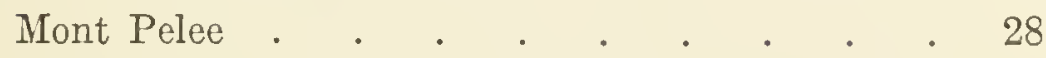
Sunset in the West Indies . . . . . . . 46 A Guiana Shore. . . . . . . . 70 A Tropical Roadside . . . . . . . . 86 A Hoatzin Swamp . . . . . . . 118 Nestling Hoatzin Climbing with Thumb and Forefinger . . . . . . . . . 134 The Laboratory in the Jungle . . . . . 146 A Corner of Kalacoon Laboratory . . . 162 The Edge of the Jungle • . . . . . 186 Jungle near the Convict Trail . . . . . 202 Pit Number Five . . . . . . . . . 222 Canello do Matto- the Tree of the Birds . . 242 The Jungle • • . . . . . . . 268 A Watcher in the Jungle . . . . . . 280 



\section{JUNGLE PEACE}

AfTer creeping through slime-filled holes beneath the shrieking of swift metal, after splashing one's plane through companionable clouds three miles above the little jagged, hero-filled ditches, and dodging other sudden-born clouds of nauseous fumes and blasting heart of steei; after these, one craves thoughts of comfortable hens, sweet apple orchards, or ineffable themes of opera. And when nerves have cried for a time ' enough' and an unsteady hand threatens to turn a joy stick into a sign post to Charon, the mind seeks amelioration-some symbol of worthy content and peace-and for my part, I turn with all desire to the jungles of the tropics.

If one looks the jungle straight in the face and transcribes what is seen, there is evolved technical science, and until this can be done with accuracy and discretion, one can never feel worthy now and then, of stealing quietly up a 
side aisle of the great green wonderland, and, as I have done in these pages, looking obliquely at all things, observing them as actors and companions rather than as species and varieties; softening facts with quiet meditation, leavening science with thoughts of the sheer joy of existence. It should be possible occasionally to achieve this and yet to return to science enriched and with enthusiasm, and again to play some little part in the great physical strugglethat wonderful strife which must give to future peace and contentment new appreciation, a worthier enjoyment.

It is possible to enter a jungle and become acutely aware of poison fang and rending claw -much as a pacifist considers the high adventure of righteous war. But it is infinitely more wonderful and altogether satisfying to slip quietly and receptively into the life of the jungle, to accept all things as worthy and reasonable; to sense the beauty, the joy, the majestic serenity of this age-old fraternity of nature, into whose sanctuary man's entrance is unnoticed, his absence unregretted. The peace of the jungle is beyond all telling. 


\section{SEA-WRACK}

SUSPENDED in the naked air eight thousand feet above New York, I look down and see the city and its inhabitants merged into one. From this height the metropolis is less interesting and hardly more noticeable than many tropical ants' nests which have come under my observation. Circling slcwly earthward, I have watched the city split apart into its canyon streets, and have finally distinguished the caterpillars which I knew were trains, and the black beetles which must be automobiles. Last, and apparently least, were resolved a multitude of tiny specks, weird beings all hats and legs, which were undoubtedly the makers and owners of these beetles and worms and canyons.

In many similar bird's-eye-views of the city one phase of activity always amuses and thrills. Circling as low as I dare, bumped and jolted by the surging uprush of invisible spouts of 
warm air, I head, like a frigate-bird, straight into the teeth of the wind and hang for a time parallel with the streaming lines of gray and white smoke. Near the margin of the city where the glittering water reaches long fingers in between the wharves, a crowd of people push, antwise, down to the brink. Many burdened individuals pass and repass over slender bridges or gang-planks, for all the world like leaf-cutting ants transporting their booty over twigs and grass stems. Then comes a frantic waving of antennæ, (or are they handkerchiefs), and finally part of the wharf detaches itself and is slowly separated from the city. Now I can mount higher to a less dangerous altitude and watch the ship become a drifting leaf, then a floating mote, to vanish at last over a curve of the world. I cease chuckling into the roar of my motor; my amusement becomes all thrill. The gods shift and change: Yoharneth-Lahai leaves me, and in his place comes Slid, with the hand of Roon beside me on the wheel. I hasten hangarwards with the gulls which are beating towards their roosting sands of far Long Island beaches.

On some future day I in my turn, scurry up 
a gang-plank laden with my own particular bundles, following days of haste and nights of planning. I go out on the upper deck of the vessel, look upward at a gull and think of the amusing side of all the fuss and preparation, the farewells, the departure, which sufficient perspective gives. And then I look ahead, out toward the blue-black ocean, and up again to the passing gulls, and the old, yet ever new thrill of travel, of exploration, possesses me. Even if now the thrill is shared by none other, if I must stand alone at the rail watching the bow dip to the first swell outside the harbor, I am yet glad to be one of the ants which has escaped from the turmoil of the great nest, to drift for a while on this tossing leaf.

At the earnest of winter-whether biting frost or flurry of snowflakes-a woodchuck mounts his little moraine of trampled earth, looks about upon the saddening world, disapproves, and descends to his long winter's sleep. An exact parallel may be observed in the average passenger. As the close perspective of home, of streets, of terrestrial society slips away, and his timid eyes gaze upon the unwonted sight of a horizon-a level horizon unobstructed by any 
obstacles of man's devising, mental and physical activity desert him: he hibernates. He swathes himself, larva-like - in many wrappings, and encases himself in the angular cocoons furnished for the purpose at one dollar each by the deck steward; or he haunts the smoking room, and under the stimulus of unaccustomed beverages enters into arguments at levels of intelligence and logic which would hardly tax the powers of Pithecanthropus or a Bushman.

From the moment of sailing $I$ am always impressed with the amusing terrestrial instincts of most human beings. They leave their fellows and the very wharf itself with regret, and no sooner are they surrounded by old ocean than their desires fly ahead to the day of freedom from this transitory aquatic prison. En route, every thought, every worry, every hope is centripetal. The littlenesses of ship life are magnified to subjects of vital importance, and so perennial and enthusiastic are these discussions that it seems as if the neighbor's accent, the daily dessert, the sempiternal post-mortem of the bridge game, the home life of the stewardess, must contain elements of greatness and goodness. With a few phonograph records it would 
not be a difficult matter to dictate in advance a satisfactory part in the average conversation at the Captain's table. The subjects, almost without exception, are capable of prediction, the remarks and points of view may be anticipated.

Occasionally a passenger detaches his mind from the ship and its doings long enough to take note of something happening beyond the railsome cosmic phenomenon which he indicates with unerring finger as a beautiful sunset, frequently reassuring himself of our recognition by a careful enumeration of his conception of the colors. Or a school of dolphins undulates through two mediums, and is announced, in a commendably Adam-like, but quite inaccurate spirit, as porpoises or young whales. Mercury, setting laggardly in the west, is gilded anew by our informant as a lightship, or some phare off Cape Imagination. We shall draw a veil or go below, when an "average citizen" begins to expound the stars and constellations.

All this is only amusing, and with the limited interest in the ship and the trip which the usual passenger permits himself, he still derives an amazing amount of pleasure from it all. It is a wonderful child-like joy, whether of convinc- 
ingly misnaming stars, enthusiastically playing an atrocious game of shuffle-board, or estimating the ship's log with methods of cunning mathematical accuracy, but hopeless financial results. All these things I have done and shall doubtless continue to do on future voyages, but there is an additional joy of striving to break with precedent, to concentrate on the alluring possibilities of new experiences, new discoveries, on board ship.

If the ressel is an oasis in a desert, or in a "waste of waters" as is usually announced at table about the second or third day out, then I am a true Arab, or, to follow more closely the dinner simile, a Jonah of sorts, for my interest is so much more with the said waste, or the things in it and above it, than with my swathed, hibernating fellow mortals.

Precedent on board ship is not easily to be broken, and much depends on the personality of the Captain. If he has dipped into littleknown places all over the world with which you are familiar, or if you show appreciation of a Captain's point of view, the battle is won. A few remarks about the difficulty of navigation of Nippon's Inland Sea, a rebuke of some 
thoughtless idiot at table who hopes for a storm; such things soon draw forth casual inquiries on his side, and when a Captain begins to ask questions, the freedom of the chart-room is yours, and your unheard-of requests which only a naturalist could invent or desire, will not fail of fulfilment.

I am off on a voyage of two weeks to British Guiana and I begin to ponder the solution of my first problem. 'The ressel plows along at a ten-knot rate, through waters teeming with interesting life and stopping at islands where every moment ashore is of thrilling scientific possibility. By what means can I achieve the impossible and study the life of this great ocean as we slip rapidly through it-an ocean so allencompassing, yet to a passenger, so inaccessible.

Day after day I scan the surface for momentary glimpses of cetaceans, and the air for passing sea birds. Even the rigging, at certain seasons, is worth watching as a resting place for migrating birds. The extreme bow is one of the best points of vantage, but the spot of all spots for an observer is the appropriately named crow's nest, high up on the foremast. You have indeed won the Captain over to your 
bizarre activities when he accords permission to climb the swaying ratlines and heave yourself into that wonderful place. It is tame enough when compared with piloting a plane among the clouds, but it presents an enormous expanse of ocean compared with the humble deck view. Here you can follow the small whales or blackfish down and down long after they have sounded; with your binoculars you can see every detail of the great floating turtles. And when the sun sinks in glory which is terrible in its grandeur, you may let it fill your senses with wordless ecstasy, without fear of interpretive interruption. Save for the other matchstick mast and the spider-web ratlines, the horizon is unbroken.

Many years ago I spent a night in the torch of the Statue of Liberty and each time I dozed, the twenty odd inch arch through which the lofty structure swayed, awoke me again and again, being changed, behind one's closed lids, into a single motion, apparently that of a gradually accelerated fall to earth. In the crow's nest, when the ship is rolling, I can often conjure up the same feeling when my eyes are shut, but now I react to a new stimulus 
and instinctively reach for a steering rod, as the sensation is that of a wing slip, consequent upon too slow progress of an aeroplane.

Among the luggage which I take on board is invariably a large, eight-pronged, iron grapple, with a long coil of rope. These the stewards eye askance when they place them in my cabin, and hold whispered consultations as to their possible use. It is by no accident or chance that before the third day I have won the attention and a certain amount of interest of the Captain and have obtained permission to put his vessel to a novel use. About the fourth day, from the upper deck or the ship's bow, I begin to see floating patches of seaweed-gulfweed or sargasso as it is called. For the most part this appears as single stems or in small rounded heads, awash with the surface. But as we proceed southward larger masses appear, and then, with my assistant, I get my crude apparatus ready. We fasten one end of the coil of rope to the rail of the lowest open deck forward, and then I mount the rail, securing a good grip with legs and feet. As a cowboy on a fractious horse gathers the loops of his lariat for the throw, so I estimate my distance 
and balance myself for the propitious moment. Now if not before, the audience gathers. It is flattering to see how quickly my performance will empty the smoking room, put an end to bridge games and fill the deck chairs with deserted, outspread yellow-backs. As dangerous rival attractions, I admit only boat-drill and the dinner gong!

My whole object is of course to secure as much as possible of the sargasso weed together with its strange inhabitants, and to this end I have tramped the decks of steamers with the patience of the pedestrian of Chillon. I have learned the exact portions of the vessels where the strain is the least, and where the water, outflung from the bow is redrawn most closely to the vessel's side. I have had overheavy grapples dragged from my hand and barely escaped following the lost instrument. I have seen toolight irons skip along the surface, touching only the high spots of the waves. As one drops one's aerial bomb well in advance of the object aimed at, so I have had to learn to adjust the advance of my cast to the speed of the ship.

I make throw after throw in vain, and my 
audience is beginning to jeer and to threaten to return to the unfinished no trumps, or the final chapter of "The Lure of Love." Near the water level as I am, I can yet see ahead a big 'slick' of golden brown, and I wait. But the bow dips farther and farther away and I almost give up hope. Then I look up appealingly to the bridge and catch a twinkle in the Captain's eye. Even as I look he motions to the wheelman and the second succeeding dip of the bow slews it nearer the aquatic golden field. Still more it swings to starboard and at last crashes down into the very heart of the dense mass of weed. The frothing water alongside is thick with the tangle of floating vegetation, and it is impossible to miss. I throw and lean far over, dragging the grapple until its arms are packed full. Then with all my strength I draw up, hand over hand, leaning far out so it will not bang against the side, and dump the dripping mass on the deck. My helper instantly frees the prongs and I make a second cast and get another rich haul before the last of the field of weed drifts astern and tarnishes the emerald foam of the propeller churned wake. 
For a few minutes there is wild excitement. My audience dances and shouts with enthusiasm from the upper rails, members of the crew appear and help me pursue agile crabs and flopping fish about the deck. Even the surly old mate roars down news of another batch of weed ahead, and I curb my curiosity and again mount my precarious roost.

In the course of several days I acquire a wonderful sunburn, considerable accuracy in flinging my octodont, and finally a series of tumblers of very interesting specimens, which furnish me with many new facts, and my fellow passengers with the means to kill much of that embarrassing concomitant of ocean voyagestime.

An amazing amount of fiction and nonsense has been written about the sargasso weed, but the truth is actually more unbelievable. Though we see it in such immense patches, and although for days the ocean may be flecked with the scattered heads of the weed, yet it is no more at home in mid-ocean than the falling leaves in autumn may claim as their place of abode, the breeze which whirls them abou+, or the moss upon which at last they come to rest. Along 


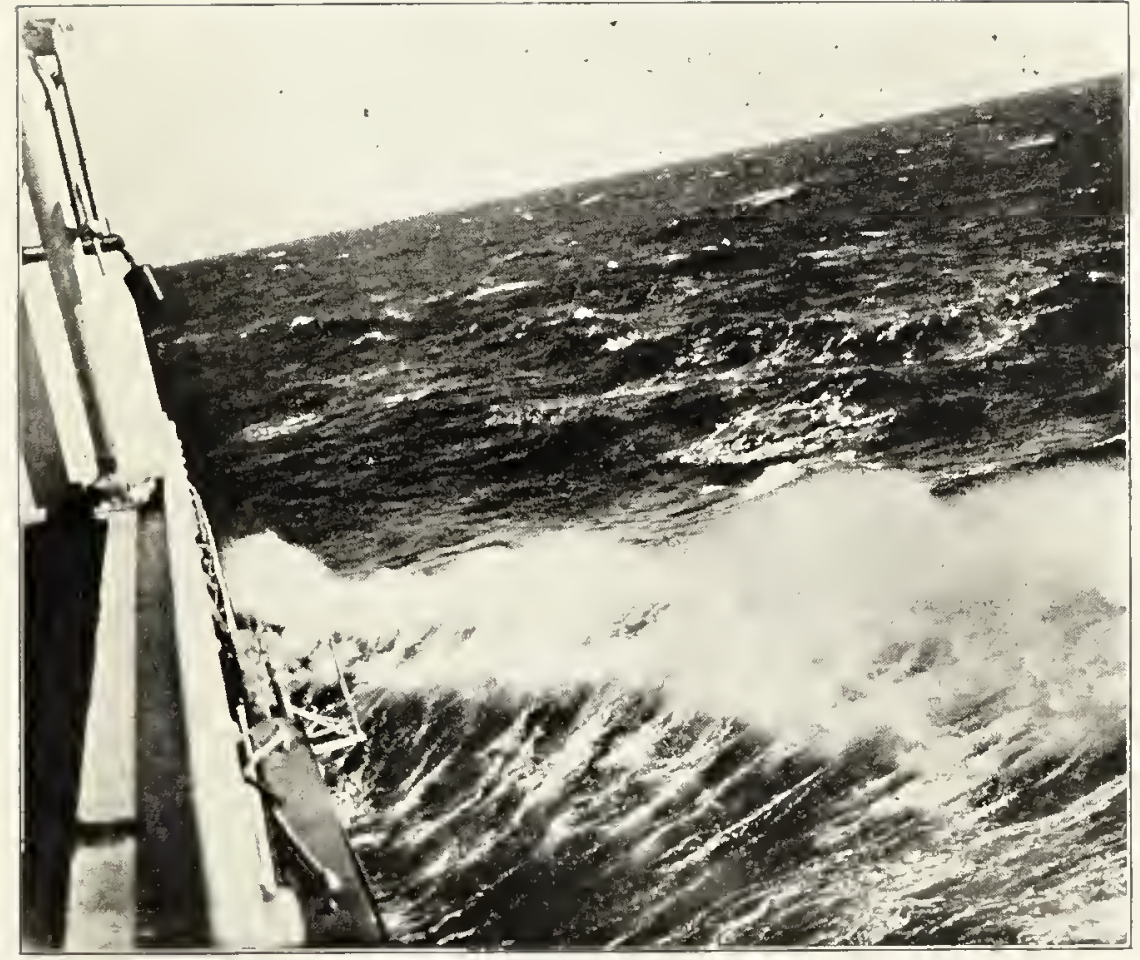

Where the Sargasso Floats 

the coast of Central America the sargasso weed grows, clinging, as is the way with seaweeds, to coral and rock and shell, and flowering and fruiting after its lowly fashion. The berry-like bladders with which the stems are strung, are filled with gas and enable the plants to maintain their position regardless of the state of the tide. Vast quantities are torn away by the waves and drift out to sea and these stray masses are what we see on every trip south, and which, caught in the great mid-ocean eddy, form the so-called Sargasso Sea. Just as the unfailing fall of dead leaves has brought about a forest loving clique of brown and russet colored small folkfrogs, crickets, lizards, birds and mammals which spend much of their life hiding beneath or living upon the brown dead leaves, so this neverending drift of weed has evolved about it a little world of life, a microcosmos of great intimacy, striving by imitation of frond and berry and color to avoid some of the host of enemies forever on the lookout.

It is possible to place a bit of weed in a tumbler of salt water and have a dozen people examine it without seeing anything but a yellowish brown frond with many long, narrow leaves 
and a number of berry-like structures, Here and there are patches of thin ivory-white shells -tiny whorls glued closely to the surface of the leaves. Yet on this same small piece of weed there may be several good-sized crabs, sluglike creatures, shrimps and a fish two or three inches in length. Until they move, the eye is powerless to detach them. No two are alike; the little frog-fish is mottled and striped, with many small flabby filaments, and apparently ragged fins, with curious hand-like fore limbs which clutch the fronds closely. The pipe-fish and sea-horses are draped and ragged, and splashed with yellow and brown, the slugs are simply flaccid stems or leaves, and the crabs are beyond belief, living bits of weed. Some are clear yellow, others are mottled, others again have white enameled spots like the small masses of tiny shells. The little shrimps are mere ghosts of life, transparent, yielding to every movement of the water-altogether marvelous. Then there are other beings, blue like the sea, white like the foam, or translucent bits of disembodied organs. This is all absorbingly wonderful, but the unreality of this little world's existence, the remembrance of its instability is 
always present, and the tragedy of the immediate future looms large.

The weed along the coast is honest growth, with promise of permanence. The great floating Sargasso Sea is permanent only in appearance, and when finally the big masses drift, with all their lesser, attendant freight into the gulf stream, then life becomes a sham. There can be no more fruiting or sustained development of gas-filled berries. No eggs of fish or crabs will hatch, no new generation of sea-horses or mollusks appear among the stems. Bravely the fronds float along, day by day the hundred little lives breathe and feed and cling to their drifting home. But soon the gas berries decay and the fronds sink lower and lower. As the current flows northward, and the water becomes colder the crabs move less rapidly, the fish nibble less eagerly at the bits of passing food. Soon a sea-horse lets go and falls slowly downward, to be snapped up at once or to sink steadily into the eternal dusk and black night of deeper fathoms. Soon the plant follows and like all its chilled pensioners, dies. The supply from the Sargasso Sea seems unfailing, but one's sympathies are touched by these little assemblages, 
so teeming with the hope of life, all doomed by the current which is at once their support, their breath and their kismet.

But all these creatures, interesting as they are, form but a tithe of the life existing around and beneath the ship. Night after night I lean over the bow and watch the phosphorescence flare and flash beneath the surface, the disturbance of the steamer's approach springing a myriad of these floating mines, whose explosions, gentler than those of human make, merely vibrate into a splendor of visibility. How to capture these tiny beings which the eye can scarcely resolve is a matter far more difficult than the netting of the seaweed. I try to plan, then give it up. I walk restlessly over the vessel, seeking some method. But, as is often the case, nature had fairly to force the solution upon me. Thoreau says somewhere, "A trout in the milk is pretty good circumstantial evidence," and in similar guise I saw the light. Early one morning I was paddling in my salt-water bath, thinking of the coming week when I should be able to dive into island harbors from the deck, when I sat up suddenly at the sight of a tiny fish disporting himself with me in the tub. At least I needed no further hint, 
and as I scooped up the little being my plan was made. By exhaustive inquiry among the feminine portion of the passengers I obtained possession of a small square of a very fine-meshed fabric something like bolting cloth. In the evening, with the assurance of a small monetary liaison with the bath steward, I tied this bit of cloth over the salt-water nozzle and carefully set the faucet so that a dribble of water trickled forth. In the morning the cloth strainer contained a small blob of grayish jelly. This I dropped into a tumbler and saw the water cloud with an opalescent mist of a myriad motes and I knew that my plan was successful. No matter how tempestuous the sea, or at what speed the ship throbbed through the water, I would always be able to gather any amount of the wonderful floating life of the ocean-the phosphorescent plankton-for my microscope. Again, aside from my own edification, I was able to give some thrills to my fellow passengers, and I have had twenty or more lined up for a squint at the weird things of the open sea. In spite of my reassurances, there was reported to be less enthusiasm for the daily bath, and much suspicious inspection of the clear ocean tub water 
as a result of glimpses of the concentrated cosmos in my tumblers.

I can recall many similar diversions and discoveries of new possibilities of life on board ship, but one brings memories of especial delight. Next to the crow's nest the bow is, for me, the place of greatest joy-the spot where each moment one's eyes reach forward into a trackless, unexplored field of view; a heaving, translucent No Man's Land, fraught with potentialities such as sea-serpents. Long had I pondered the possibility of getting nearer the fascinating bit of unbroken water just ahead. At last a scheme unfolded itself, but not until a following trip when I had made all preparations did I venture to ask permission of the Captain. For I knew better than to wish to add anything to the responsibility of this official. When he had become used to my eccentric use of the deck and the bath tubs, I unfolded my new plan, and thanks to my preparation, met with no opposition. I had a waistcoat made of stout leather straps, with a heavy ring behind to which I attached a strong rope. This tethered to the rail, in the extreme bow, enabled me to swarm safely down until I 
reached the flukes of the great anchor. Seating myself comfortably, I lashed my leather straps fast, and was ready for work with glass or net or camera. Of course this was possible only on comparatively calm days, but when the sea was mirror-like, with only the low, heaving swells bending its surface, and the flying fish flushed before us in schools, then I had days of good sport.

This novel method of anchor perching led indirectly to the solution of a very different puzzle. I had been thinking and talking of the congested turmoil of the great city far below the horizon to the north. Looking back on a year in its midst, memory, aroused by present contrasts, registered sham, insincerity, deceit, illusion, veneer as dominant notes in civilization. In an argument one evening $I$ had held that deceit or illusion was not of necessity evil, nor when unconsciously self-imposed, even reprehensible.

The next day I instanced a rather apt example. Our very knowledge, our mental mastery leads us to false sensory assertions, which become so universal that they develop into apparent truisms. Only by a distinct effort may 
we summon them to consciousness and correctly orient them. It is not without a wrench that we set aside the evidence of our senses and realize the proof which physics offers. We watch the glorious "sunset" and to disillusion our minds require to repeat again and again that it is the earth which is heaving upward, the horizon which is eclipsing the sun and the sky of day. I once persuaded a group of passengers to speak only of the evening's " earthrise" and in three or four days this term had become reasonable, and almost lost its strangeness.

One finds numerous examples of these sensory deceits at sea; our senses are at fault in every direction. The wind flutters the fins of the flying fish and we think they actually fly. The tropic sea, under the palest of green skies, is saturated ultramarine, save where the propellers churn it to pea-green, yet in our bath the water is clear and colorless.

My most interesting oceanic illusion, was a personal one, a result of memory. I looked about the ship and felt that this at least was wholly sincere; it was made to fulfil every function and it achieved its destiny day by day, 
finally and completely. I had never sailed on a vessel of this name before, the "Yamaro," and yet at certain moments an oblique glance brought a flash of memory, of a familiar hatchway, a rail which fitted snugly under one's elbows, a stretch of open deck which seemed too much of a known path for these few days' acquaintance. As I talked with the Trinidad negro lookout on the forward deck, I saw a brass coolie plate roll out of the galley, and I wondered. There were only negroes among the crew. Then one day I donned my leather waistcoat and climbed down to my anchor flukes, and my mystery was solved. In clear new letters the name of the vessel appeared along the side of the bow above me, but a second glance showed me something else: a palimpsest of old corroded sites of four letters, painted out, which once had sent their message to so many inquiring eyes: Pegu.

Long ago, on trips of unalloyed happiness, I had traveled between Colombo and Rangoon on this selfsame steamer, which now, caught in some unusual stress of distant demand of war, had with her sister ships been taken from her 
route in the Far East and settled to her new routine.

So even the ship beneath me was not what she had seemed, and yet her deceit and illusion were harmless, wholly without guile, and I began to wonder whether my unfriendly thoughts of the great city behind me were quite fair.

The carven Wodens and Brünnhildes who guarded the fortunes of old Viking ships, watched the icy Arctic waters forever cleft beneath them and felt the sting of flying splinters of ice; the figureheads of Gloucester merchantmen of old, with wind blown draperies and pious hands, counted the daily and monthly growth of barnacles, and noted the lengthening of the green fronds on the hull below. One day I lay in the great arms of an anchor, beneath a prosaic bow; myself the only figurehead, peering gargoyle-wise over the new-painted steel. Far below, in place of wooden virgin or muscled Neptune, there appeared only four numbers, 2, 3, 4 and 25. Even these, however, yielded to imagination when I remembered that the light cargo which made them visible was due to the need of sugar by soldiers in far distant trenches. 
The great unlovely bow rose and reached forward and settled until, as I lay face downward, our speed seemed increased many fold. And I wondered if the set wooden expression which always marked the figurehead ladies and gods had not its origin in the hypnotic joy of forever watching the molten cobalt crash into alabaster, this to emerald, then to merge again into the blue which is a hue born of depth and space and not of pigment. And now I forgot the plunging bow beneath and the schools of toy biplanes, the strange little grasshopper-like fish which burst from the ultramarine, unstained, full-finned and banked sharply outward for their brief span of flight. I looked up and saw palegreen shallows, a thread of silver surf and the rounded mountains of a tropical island. And I frowned with impatience-something that more reliable figureheads never did--for the island, teeming with interest, with exciting birds, and fascinating people, had been spoiled for me. Force of circumstance had shuffled me inextricably into a pack ( $\mathrm{I}$ use the simile advisedly) of insufferable tourists. Effeminate men, childish women and spoiled children diluted or wholly eclipsed every possible scene. The obvious 
was made blatant, the superficial was imagined subtle, the glories of silent appreciation were shattered by garrulous nothings. At the thought of such fellow countrymen I hid my face and strived with all my might to obliterate the remembrance. Soothed by the rise and thrust of the great ship's bow and the intermittent roar of the steel-born breaker beneath, I rested motionless.

When at last I roused, it was with a start at the altered scene. It seemed as if my thought -Buddha-powerful-had actually wrought the magic of widespread change. The alabaster breaker was there, but oxidized, dulled; the cobalt had become gray-black, and by the same alchemy the emerald shallows were reset with a mosaic of age-dimmed jade. Most of all was the island changed. From strand to cloudcapped peak, the tone was purple. In high lights it hued to dull silver-gray, in the shadows it deadened to utter black. Rugged and sheer Mont Pelee drew upwards, its head in cloud, its feet in the sea-the shadow-gray sea. My eye strove to penetrate the cloud and picked from its heart a thread of black among the gray lava, which, dropping downward, enlarged 


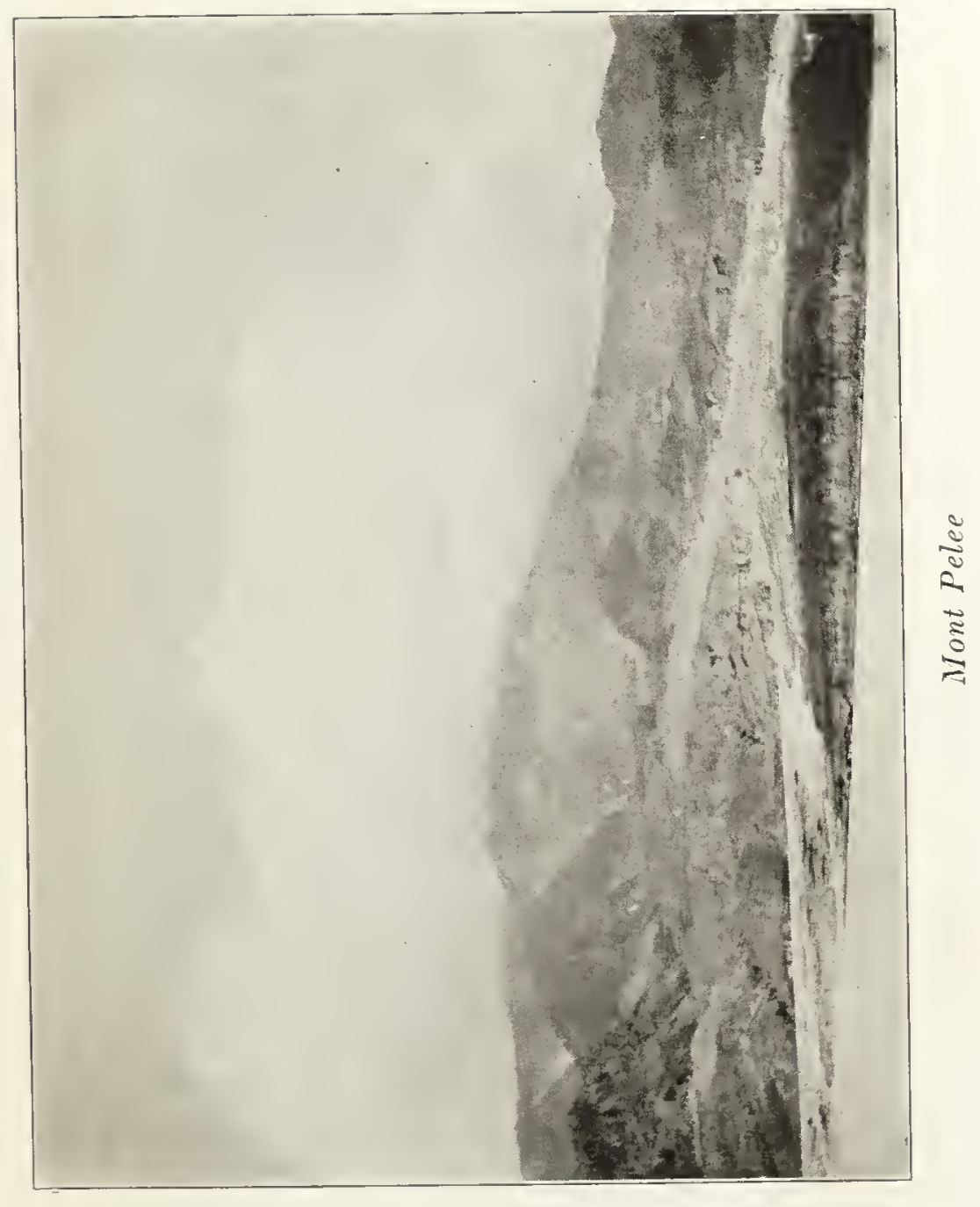



to a ribbon and then to a gully. In ugly angles and sharp, unreasonable bends it zigzagged down the shoulder of the great cinderous mountain. Before I realized it my gully became a gorge and ended at the edge of the dark waters, as black and as mysterious as it had begun.

Idly, I lay and watched the silver shuttle of coral-shattered foam weaving the warp and woof of the rising tide along the whole length of shore. This seemed the only bit of land in the whole world. Was it the first-or the last-to appear above the waters? It might have been either, until, suddenly I saw a movement among what I had taken for huge, crater-spewed boulders, but which I now knew for the weathered remains of a city. From between two walls of this city of the dead came slowly into view the last human being in the world-or so the surroundings suggested. Yet a second glance belied this, for her mission was fraught with hope. Even at this distance I could discern her stately carriage, swinging and free, her black countenance and her heavy burden. At the very edge of the water she stopped, lifted down the basket piled with black volcanic débris and emptied it. She stood up, looked 
steadily out at the passing steamer and vanished among the shadows of the ruins. It was startlingly like the first grain of sand which an ant brings out after a passing heel has crushed its nest. But however vivid the simile, the dominant thought was hope. At least one ant had faith in a new ant-nest of the future, and the somber picture of the negress, her basket of black lava poured into the equally black waters, was suddenly framed in high relief by the thought of a new St. Pierre. The great mountain still rumbled and smoked. One at least believed in a home in its very shadows.

But the end was not yet. The island had been for me unhappily visited; its passing had been a sudden, wonderfully dynamic vision. And now I shut my eyes again to strive to interpret and to fix indelibly in mind this vision and all the network of thoughts it wove. Again the roar from below and the gentle rise and forward surge calmed and rested me. And the thought of the unhappy morning was become dim and carried no resentment.

Ten minutes later I looked up again and found all changed-no ruthless, startling shift 
of values, but a subtle, all-wonderful transformation. Pelce should still have loomed high, the craters and gullys were but a short distance away and indeed all were faintly discernible. A faint veil of azure had intervened. There was no wind, it had neither drifted in from the sea nor frayed from the edges of the dense cloud which enveloped the peak. So evanescent, so delicate was this still-born haze that the crater cloud was only softened, not eclipsed. From the strong sweep and stroke and virile outline of a Brangwyn or the gnomesque possibilities of a Rackham, the great mountain softened to the ethereal air castle of a Parrish. Between winks, as imperceptibly as the coming of twilight to a cloudless sky, the vision changed to a veritable Isle of Death. This seemed too evanescent, too ethereally fragile to endure, and yet for moment after moment it held and held-and then the mountain-which was yet but the shadow of a mountain-this itself dissolved, and over the gently heaving sea, were neither lava flows nor cinders, gorges nor ruins, but only a faint pearly-white mist, translucent, permeable, floating softly between sea and sky. Martinique 
had vanished-had dissolved-there was no longer any land above the waters.

Dusk settled quickly and the vision remained unbroken. All my sensory relations with the world seemed inverted. My actual contact with the island had passed into happy forgetfulness; the coastal vision was more vivid and real, and now, the essence of memory, the vital, tangible retrospect was forever bound up in the final vanishing, the very evaporation of this islandlapped by the sea-the sea which tomorrow's sun would fill with the glorious hue of sapphires -the sapphires of Kashmir. 


\section{ISLANDS}

Wirth thrice seven-league boots one could stride from the coast of the United States and with a dozen steps reach British Guiana dryshod. From an aviator's seat, the chain of West Indies, Windward and Leeward Islands curves gracefully southwards, Hike stepping-stones across a Japanese stream. If, corresponding to this annihilation of space, we could abbreviate minutes, hours and days as in a moving-picture film, we might have the edifying spectacle of our steamer's trip reduced to a succession of loops, ricochetting from island after island, as a stone skips along the surface of the water, sliding along those dotted lines which are so characteristic a feature of coasts in our school geographies, and coming to rest at last with a splash in the muddy current off the Georgetown stelling.

Our steamer is preferable to the seven-league 
trip, for we thereby omit the big, cumbersome West Indies. It is a curious fact that any land projecting above the surface of the water is interesting and exciting in inverse ratio to its size. The endless New Jersey shore moves one not at all, while the single volcanic cone of Nevis brings thrills and emotions; Cuba is wearisome as one steams slowly past headland after headland, while Sombrero-a veritable oceanic speck of dust-stimulates the imagination to the highest pitch. It seems as if our Ego enlarges as our immediate terrestrial cosmos diminishes. In studying the birds of the endless jungles of the South American continent my interest never flags, yet it never quite attains the $n$th power of enthusiasm which accompanies the thought of the possibility of locating every nest on St. Thomas. This love of small islands must savor of the joy of possible completeness in achievement, plus a king's sensations, plus some of those of Adam!

Any guide book will give the area, population, amusements, best hotels (or the least objectionable ones), summary of history and the more important exports. But no one has ever attempted to tell of the soul of these islands- 
or even of the individuality of each, which is very real and very distinct. Some day this will be done, and the telling will be very wonderful, and will use up most of the superlatives in our language. For my part I may only search my memory for some little unimportant scene which lives again when the name of the island is spoken-and string these at random on pages, like the chains of little scarlet and black sea-beans which glisten in the fingers of the negresses, held up in hope of sale from their leaky boats, rocking on the liquid emerald around the steamer.

St. Thomas, on How I Was Taught to Catch Lizards by a Danish Flapper.Nearly a week had passed since we began to exchange a sleety winter for the velvety tropics, to traverse the latitude spectrum of ocean from drab-gray to living turquoise. As on every trip, it was early morning when the long undulating profile of St. Thomas reared itself lazily from the sea, and almost at once, flocks of greatwinged booby-gannets began to wheel and veer around the ship, banking in a way to make an aviator's blood leap.

From a dusky monochrome the land resolved 
into shades, and slowly into colors-gray volcanic rocks, dry yellow turf and green patches of trees. Then contours became traceable, smooth rounded shoulders of hills frayed out into jagged strata, with the close-shaven fur of bushes and shrubs, and occasional tall slender palms reminding one of single hydroids on the sargasso fronds. A thread of smoke drifting free from a palm grove was the first sign of life, and after a few minutes of twisting and turning, the steamer nosed out her circuitous channel, and from the very heart of the island the great crater harbor opened before us.

The beautiful hills rolled up and upward, and to their feet Charlotte Amalie, crowned with Bluebeard's castle, clung obliquely, her streets climbing with astonishing steepness. The little town was newly roofed, all the picturesque old red ones having been ripped off in the last hurricane. The houses were as flat, quite as like cardboard theatrical scenery as ever.

At the sight of a distant flag I endeavored to thrill patriotically at the thought that this island was now a part of the United States. I would have been more successful, however, if I could have recalled the vision of some fellow 
countryman in far distant time, landing on these slopes and taking possession by right of discovery. Even if some burly, semi-piratical American adventurer had annexed it for his president by feat of arms, my blood would have flowed less calmly than it did at the thought of so many millions of dollars paid as droit de possession. However, a tropic bird flew past and put the lesser matter out of mind.

As always, near the wharf thrived the same little open bar-room, with its floral-bedecked mirrors, selling good beer and vile soda. Aside from a flag here and there, the only sign of the change of nationality was several motorcycles with side cars which American soldiers drove like Jehu through the narrow streets, hustling natives and their tiny carts and ponies to one side, and leaving enduring trains of gasolinescented dust. A few minutes' walk up one of the steep streets and all was quiet and unhurried, and the sense of a yet undigested possession, of embarrassing novelty of purchase, slipped aside and we knew that St. Thomas was still the unspoiled little island which the slow mellowing growth of West Indian evolution had made it. We climbed slowly up the 
steep road toward Mafolie, and behind us the glory of this wonderful island unfolded and spread, the roofs of the town shifting into strange geometric figures, and the harbor circle widening. We passed pleasant sunburned Danes and negroes driving tiny burros laden with small fagots and with grass. At one turn a tamarind tree was in full blossom, and here were gathered all the hummingbirds and butterflies of the island, or so it seemed. At last we reached a ravine, dry as everything else at this season on the island, and walked slowly up it, catching butterflies. 'They were in great numbers and gayly colored. 'The strangest sight was hundreds of large, brown millipedes clinging to the stems of bushes and small trees, apparently finding more moisture in the steady tradewinds than in the soil, which even under large stones, was parched and dry: dragonflies were abundant, but the dominant forms of insect life were butterflies and spiders.

The road wound over the top of the ridge and from its summit we looked down on the other half of the island. No house or trace of cultivation was visible and the beauty of the view was beyond adequate description. Roll- 
ing, comfortably undulating hills were below us, and in front a taller, rounded one like the head of some wearied tropical giant. Beyond this, a long curved arm of richest green had been stretched carelessly out into the sea, inclosing a bay, which from our height, looked like a small pool, but such a pool as would grace a Dunsany tale. It was limpid, its surface like glass and of the most exquisite turquoise. Its inner rim was of pure white sand, a winding line bounding turquoise water and the rich, dark green of the sloping land in a flattened figure three. I never knew before that turquoise had a hundred tints and shades, but here the film nearest the sand was unbelievably pale and translucent, then a deeper sheen overlaid the surface, while the center of the pool was shaded with the indescribable pigment of sheer depth. In a great frame of shifting emerald and cobalt, set a shining blue wing of a morpho butterfly and you can visualize this wonder scene.

Outside the encircling green arm, the water of ocean glowed ultramarine in the slanting sunlight, and stretched on and on to the curving horizon of Atlantis. The scene seemed the essence of peace, and to the casual glance hardly 
a cloud moved. I sat for a long time and let every part of my retina absorb the glory of colors. Soon motion and life became apparent. Shadows shifted softly across the surface, bringing hues of delicate purplish blue, memory tints of open ocean, and against these darkened tones a thousand specks of white glowed and interweaved like a maze of motes in a shaft of sunlight. In imagination we could enlarge them to a swarm of silvery bees, and then my glasses resolved them into gannets-great sea birds with wings six feet from tip to tip-an astounding hint of the actual distance and depth below me of this pool-like bay. An hour later the sunlight left the turquoise surface, and its blueness darkened and strengthened and became opaque, although it was a long time before sunset, and the ocean beyond kept all its brilliance.

My eye was drawn to two tiny dots on the sandy rim. I could just make out that they were moving and guessed them to be dogs or chickens. The glasses made magic again and split up each group into a triumvirate of little burros which trotted along, and presently turned into an invisible side trail. Perhaps the most 
fascinating discovery of motion was that of the water's edge. 'To the eye there were neither waves nor ripples, but careful scrutiny through the strong prisms showed a rhythmical approach and receding, a gentle breathlike pulsation which regularly darkened and uncovered a thread of sand. I forgot the busy little town on the other side of the island, the commerce and coaling and the distant echo of war, and giving a last look at the tarnished turquoise pool, the resentment of financial acquisition of such beauty softened, and I felt glad that I had indirectly some small tithe of ownership, as well as the complete memory monopoly of the glories of this passing day.

As I made my way down the ravine, the fascinating island lizards scrambled about or watched me knowingly from rock or tree-trunk. As usual I wrecked my net in striving to sweep them into it, and bruised my fingers in vain efforts to seize their slender forms. Rarely I succeeded; usually I found but a bit of tail in my fingers, or a handful of loose bark, while, just out of reach, they would halt and look me over derisively with their bright intelligent eyes. At the roadside I came suddenly upon a little 
Danish girl of about twelve years, dancing excitedly with a lizard dangling from the end of a slender grass stem.

Her blue eyes flashed with excitement, her yellow pigtail flew wildly about as she danced and backed away, fearful of touching the little lizard, and yet too fascinated to drop it and allow it to escape. I took it up and found it had been captured with a neat slip noose. She said it was easy to catch them and showed me how, and before I reached the wharf I had a dozen of the interesting little chaps stored in various pockets. Thus after years of effort a little Danish school girl solved my problem for me. Acting on this hint I tried fine hair wire, but nothing proved as effective as the thin, pliant but strong stems of grass.

It is surprising how difficult it is to touch these little reptiles and yet how easy to noose them. At the approach of hand or net they are off faster than the eye can follow, yet they are merely interested in the waving grass. Even when by an awkward motion one flicks their nose, they merely shake their heads or shift a step or two. They detect no connection be- 
tween the moving grass and the more distant hand that wields it.

Bound to the ground by their short scales and four limbs, these small lizards are yet remarkably birdlike in their vivacity and their enthusiastic playing of their little game of life. Every motion is registered by quick wrenlike movements and by the changing play of colors over their scales, while when particularly excited, they puff out a comical dewlap of yellow and orange skin beneath their throat. Thanks to my flapper acquaintance I am now on more equal terms with the little scaly people of the islands, and can study their puzzling color problems at close range.

Looking back at Bluebeard's and Blackbeard's castles from the deck of our vessel as we slowly steamed from the harbor, some one asked when the last pirate plied his trade. I looked ashore at the fort and guns, I listened to the warning bugle, I watched the scattered lights vanish, leaving all of the town in darkness, I saw our own darkened portholes and shaded lights. As my mind went to the submarines which inspired all these precautions, as I recalled the sinister swirl in the Atlantic which 
had threatened us more than once on my return from the battle-front, I could answer truly that Bluebeard and his ilk were worthily represented at the present day. Indeed, of the two enemies, I found much more to condone in the ignorance and the frank primitive brutality of the pirate of past centuries, than in the prostituted science and camouflaged kultur of the teutonic ishmaelite of today.

St. Kitts, a Plunge, Exploration AND Monkeys.-I came on deck at daybreak and found the sea like a mirror. Fven the clouds were undisturbed, resting quietly in the mountain valleys of St. Fustatius, and on the upper slopes of St. Kitts in the distance. The tropical morning was a lazy one, and the engines seemed to throb in a half-somnolent manner. I folded up into a deck chair and idly watched the beautiful profile of the island astern.

Suddenly the sea became alive with virile beings-curving steel-gray bodies which shot forth like torpedoes from some mighty battery. I thrilled in every fiber and the sloth of the tropics fell from me as if by a galvanic shock: the dolphins had come! Usually they appear in their haunts between Dominica and Marti- 
nique or off the latter island, but here they were in dozens, leaping for breath with the regularity of machinery. Now and then the spirit of play would possess one and he vaulted high in air, ten feet above the surface, twisted and fell broadside with a slap which could be heard a half-mile away. Then several simultaneously did the same thing. A school would come close alongside, slacken speed to that of the vessel, and now and then dive beneath and appear off the opposite quarter. Another trick was for one or two to station themselves just ahead of the bow and remain motionless, urged on by the pressure of the water from behind. It was very unexpected and very splendid to have this battalion of magnificent cetaceans, bursting with vital energy and fullness of life, injected without warning into the calm quiet of this tropical sea.

We anchored off Basseterre and waited in vain for the doctor. There, seemed no chance of landing for some time, so several of us dived off and swam about the ship for an hour. The joy of this tropical water is something which can be communicated only by experience. It was so transparent that in diving one hardly 
knew the moment he would enter it. Paddling along just beneath the surface, there was a constant temptation to reach down and grasp the waving seaferns and bits of coral which seemed only just out of reach, whereas they were a good thirty feet beneath. Whether floating idly or barging clumsily along in the only fashion possible to us terrestrial humans, we longed for the sinuous power of the dolphins, whose easy sculling imparts such astounding impetus. Now and then we saw a deep swimming fish, but the line of envious fellow voyagers along the ship's rail were denied all this joy by reason of their fear of sharks. They had read in many books and they had listened to many tales, and they do not know what we shared with the little nigger boys who dive for pennies-the knowledge that the chance of an attack from a shark is about equal to that of having your ears sewed up by devil's darning needles. Over all the world I have swum among sharks; from Ceylon to the Spanish Main I have talked intimately with scores of native captains and sailors and learned the difference between what they tell to the credulous tourist and what they believe in their hearts. 


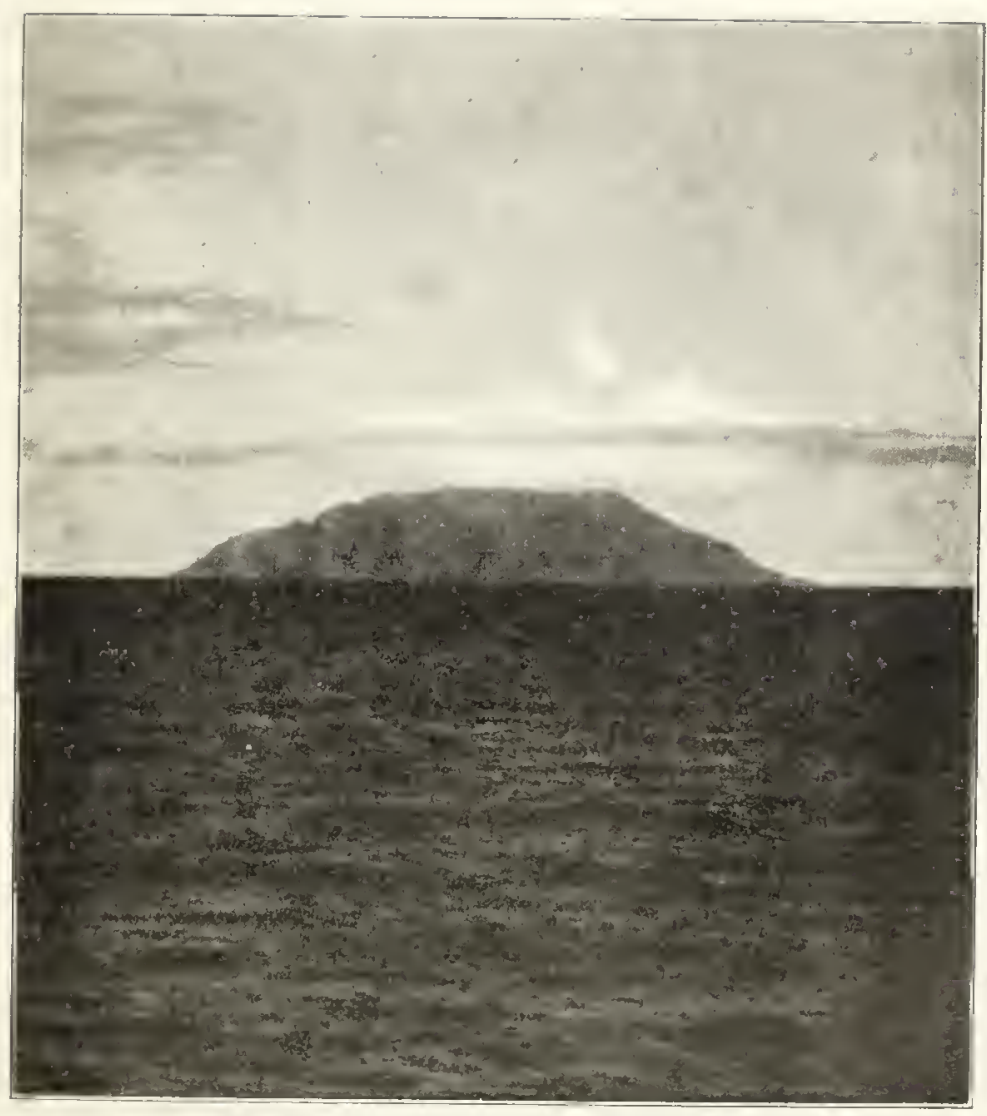

Sunset in the West Indies 

In time the St. Kitts doctor arrived, and, as he rowed past, looked at us critically as if he suspected us of infecting the water's of the sea with some of those mysteriously terrible diseases which he is always hoping for on the ship's papers, but never seems to find.

Walking hastily through the town, we reached the first of the great sugar-cane fields, and skirting these diagonally came ever nearel the sloping base of the high land. Ravines are always interesting for they cannot be cultivated, and it was up one of these lava and water-worn gullies that we began to climb Monkey Hill. We went slowly, for there were many absorbing things on the way. Palm swifts swooped about, while noisy kingbirds gleaned as industriously but with shorter flights. Heavy-billed anis rohaleeped and fluttered clumsily ahead of us; honey creepers squeaked and small black finches watched us anxiously. From a marshy pool half a dozen migrating sandpipers flew up and circled down to the shore. Every shrubby field was alive with butterflies of many kinds and the vigorous shaking of each bush yielded excellent harvests of strange insects which fell into the open umbrella held beneath. In a grove of 
wild mango and acacias were hosts of green filigree butterflies, dropping and swirling from the foliage like falling leaves, the comparison being heightened by the brown spots, like fungus blotches, which were etched upon their wings.

Leaving the ravine we climbed over great lateral shoulders of the mountain, grassy slopes with bold outjutting rocks, and rarely a clump of small shrubs, bringing to mind the lower foothills of Garhwal and Kashmir. Higher still came dense shrubby growths, much of it thorny, seamed by our narrow trail, and threaded here and there by glowing fronds of golden shower orchids. Ground doves perched on low branches and an occasional big pigeon whistled past. From the summit a wonderful view stretched out-the long, sloping green canefields, the clustered roofs, and beyond the curving beaches, the blue water with our vessel resting at anchor. Now came a search for monkeys, regardless of thorns and rough stones, for, strange though it sounds, St. Kitts possesses many of these animals. Whatever the accident of their arrival, they are firmly established and work much havoc in the small hours, among gar- 
dens and sugar-cane. Our efforts were in vain. We heard the scolding chatter of one of the small simians, and were preparing to surround him, when a warning blast from the ship summoned us and we packed up our collection of insects and flowers, munched our last piece of chocolate and began to clamber down the great sun-drenched slopes.

Martinique, or a New Use for an Eight of Hearts.-Columbus thought that this island was inhabited only by women, and to this day the market place bears out the idea. It is a place apart from all the rest of the city. In early morning, before the gaudy shutters were taken down, the streets were quiet-the callous soles of the passersby made the merest velvet shuffling and only an occasional cry of the vendor of some strange fruit or cakes broke the stillness. When yet half a block away from the market one became aurally aware of it. The air was filled with a subdued hum, an indefinite murmur which might as well be the sound of tumbling waters as of human voices. It was a communal tongue, lacking individual words, accent and grammar, and yet containing the essence of a hundred little arguments, soliloquies, 
pleadings, offers and refusals. After the aural came the olfactory zone, and none may describe this, so intermingled that fish and vegetables, spice and onions were only to be detected when one approached their respective booths.

The details of market life hold the possibilities of epic description; the transactions of a stock exchange pale into mediocrity when compared with the noise and excitement when a sixpence changes hands between Martinique negresses.

All the sales in the market were of the smallest quantities; little silver was seen, pennies, ha'pennies and sous composing all the piles of coppers. The colors of the fruits were like flowers, melons white with a delicate fretwork of green; brilliant touches of red peppers like scarlet passion flowers; tiny bits of garlic lilactinted. The fish had the hues of sunsets on their scales, and the most beautiful, the angelfish, were three for a penny, while the uglier, more edible ones, were sixpence each. Beauty was rated at inverse value here.

Around and around the iron fence which bounded the market place, paced a pitiful pair - a tiny black mite who could not have passed 
three summers, leading by the hem of an ample black skirt an old blind woman. After several halting steps they would hesitate and the gaunt hand would be thrust through the bars begging for market refuse. Once the gods were kind and a bit of melon and a spotted mango were given, but more often alms was asked of an empty stall, or within sight only of a tethered duck or chicken. Some of the gifts were no better than the garbage over which the pair stepped.

We sat in chairs in a tiny pharmacist shopthe artist and I-and were at once the center of a chattering, staring throng, a kaleidoscope of shifting colors. We shoved and dismissed to no avail, then the owner of the shop with a gentle "permitte-moi" threw a pailful of "nottoo-clean" water orer the crowd, including the artist and myself. The mob scattered shrieking and for a short time the surrounding space was open. Soon a larger crowd gathered, with the still dripping units of the first assemblage smiling expectantly in the offing, hovering at a safe distance. The second dispersal had a legal origin; the market policeman stole quietly along the wall of the shop and hurled himself like a 
catapult, butting goatlike into the heart of the crowd. A half-dozen fat negresses toppled over, and cassava, tin cups and stray fishes flew about. Even those who lost all their purchases showed no resentment but only a roaring appreciation of the joke. In this rush we were almost upset with the crowd, and we began to look forward with dread to any more strenuous defense of our comfort.

The little French mulatto pharmacist who was responsible for the occasional joyful outbursts of eau, seemed to profit by our presence, for a number of interested onlookers who had pushed into the shop to watch us from behind, when cornered and hailed by the irate owner, stammeringly asked for some small thing, by the purchase of which they bought their liberty. The regular business of this little shop alone was worthy one's whole attention. A prescription was being pounded up in a mortar and when the clerk reached out for a scoop and for something to scrape the sides clean, an eight of hearts was the nearest and with this the chemicals were mixed. Within the next fifteen minutes eight or ten different prescriptions, powders and crystals were measured, shaken, mixed 
and scraped by the same eight of hearts, and the combination of ingredients which the last purchaser obtained must surely have had some radical effect on his system-salubrious or otherwise.

Then came the unusual one-the super person who is always to be discovered sooner or later. Externally she was indistinguishable from the host of her sisters. She was garbed in a wrapper, flowing and reaching the ground, purple, and pocked with large white spots. A diminutive turban of yellow and red madras was surmounted by an ancient and crownless straw hat, but at the first word she was revealed. A British subject, she was here at the eruption fifteen years ago. That day she and one of her daughters happened to be far away from St. Pierre. When the explosion came, she was outside the danger zone, but her husband, son and other daughter were burned to death. She regretted the impoliteness of the French here and apologized for them for crowding us. Later she brought a gift of rose bananas to Mary Hammond, saying that Americans had given her food and clothes when she lost everything.

The crowd was curious, thoughtless, selfish, 
with the dominant hope a laugh at some one's expense. Here was one who sought us out, who left unguarded her little tray of bananas and garlic to speak a word of thanks, to present a handful of fruit which in her station was a munificent gift, and who was satisfied and grateful with our sincere appreciation. She has sisters in graciousness over all the world, but they are rare and widely scattered, like the Akawai Indian squaw who gave me her last cassava, like the wrinkled Japanese crone who persuaded her son to become one of my best servants, like the wife of the headman of an isolated village in Yunnan, who from among her sodden, beastlike neighbors came forth and offered fowls and vegetables with a courteous spirit worthy of any station in life.

St. Lucia, a Study in Contrasts.-Each time I have visited Castries it has seemed more somber and less pleasant. It is colorless because it is full of coal and no change of weather brings amelioration. When the sun fills the air with a blinding glare and palpitating heat waves (as it occasionally does), each step raises a cloud of coal dust, and when the tropical rain falls in a steady downpour (as it usually does), 
the whole world seems covered with coal mud, as if about to dissolve into some carboniferous slime.

This is an important military and coaling station, which perhaps explains much. Military exigency compelled me to procure a special pass from the Chief of Police to paddle about its dreary streets, and which strictly forbade my climbing the comparatively clean and attractive mountains beyond these streets. As a coaling station $I$ am sure of its success and popularity, for the coal carriers who comprise most of the natives, have apparently no time to wash between steamers. So intensive was the grime that the original dark hue of their skins offered no camouflage to the anthracite palimpsest which overlaid it. Such huge negro women, such muscles, such sense of power, I had never before sensed. I should dislike, were I an official of St. Lucia, to take any decided stand on an anti-feminine platform. So saturated are the people in coal, such is their lack of proper perspective of this material, they seem actually to be unconscious of its presence. Returning on board, one passes the Seaview Hotel, about which coal is piled to a much greater 
height than the roof. Such abstraction is worthy of mention at least.

Amid the memory of all the dirt and damp, dull sadness, two things were unforgetable, as untouched diamonds glisten in their matrix of wet blue clay. Amid sodden clothes, unwashed hands and bestial faces, a trayful of rainbow fishes gleamed opalwise-coral, parrot and angelfish, all awaiting some unsavory purchaser. Then came the little French negress, selling fans, out of the ruck of sexless bearers of coal. When we answered her appeal with a "Non merci," her face lighted up at the courtesy of the words; "Voyons!" said she, "comme c'est gracieusement refusé!" No mortal could have resisted buying her wares after such delicate sentiment.

About five in the afternoon we parted from the gritty wharf and steamed for hour after hour along the shore. We forgot the poor, filthy, ill-mannered coal carriers, and the thought of the misery and squalor of the town passed with its vanishing, still clad in its cloak of rain. As the natives appeared to us so inferior to those of the other islands, so by some law of compensation the coast was revealed correspond- 
ingly beautiful. At four bells the sun sank on the side away from the island, in a blaze of yellow and orange with one particular cloud touching the water line with flame color, as if a mighty distant volcano had just reared its head above the sea, still in the throes of molten erection. On the opposite side were passing the dark green headlands and fiords of the land, while upward, high into the sky, there arose now and then some tremendous cloud, on fire with rich rose or salmon afterglow, or a maze of other tints defying human name or pigment. In front was the living blue water dulled by the dimming light and above all the transparent blue of the tropic sky.

Without warning, from out of the soft folded edges of one of the filmy clouds, crept a curved edge of cold steel, like some strange kind of floating shell coming forth from its cloud of smoke, and a moment later the full moon was revealed, unlike any other color note in this marvelous scene. The icy, unchanging moon craters, the more plastic island mountains fringed by the wind-shapen trees, the still more shifting waters and the evanescent cloud mist, all were played upon and saturated and stained by colors which 
were beyond words, almost beyond our appreciation. 'Tiny villages, fronted by canoes and swathed in feathery cocoanut fronds, snuggled at the foot of great volcanic and coral cliffs.

But the crowning glory was reserved for the last, when we surged past the Trois Pitons, rearing their majestic heads above all the island, hundreds and hundreds of feet into the sky. Even the moon could not top one, and after cutting into sharp, silver silhouette every leaf and branch of a moon-wide swath of trees, it buried itself behind the peak and framed the whole mountain.

A small wandering rain storm drifted against the tallest piton and split in two, one half going away down the coast and the rest passing close enough to us to shower the decks with drops. As it fell astern, it spread out fanwise and in its heart developed a ghostly lunar rainbowthe spectrum cleansed and denuded of all the garish colors of day. At first we could only sense which was the warm, which the cold side of the bow, then it strengthened and the red appeared as dull copper or amber buff, and the violet as a deeper, colder blue, cloud hue. All the time, even when the rain was falling heavi- 
est, the moon shone with full strength, and when at last we veered away from this wonder island, it was so high that thcre was no moonpath on the water, but only a living, shifting patch of a million electric wires, which wrote untold myriad messages in lunar script upon the little waves. From one fraction of time to another, the eye could detect and hold in memory innumerable strange figures, and the resemblance, if it be not sacrilege to make any simile, was only to script of languages long, long deadthe cuneiform of Babylon and the tendril spirals of Pali.

Once a faint light appeared upon the distant shore. Our steamer spoke in a short, sharp blast which thrilled us with its unexpectedness and the signal among the palms was quenched. From the great things of the cosmos, from brilliant Venus, and from the north star low in the sky, from the new splendor of Formalhaut, rising ever higher in the south, our thoughts were forced back to the littlenesses of the world war, whose faint influence reached even thus far to break the thread of our abstraction.

Barbados, in Eclipse and in Sun.-The vagaries of a naturalist are the delight of the 
uninitiated, and impress simple natives more than immoderate tips or the routine excesses of tourist folk. One's scientific eccentricities may even establish a small measure of fame, or rather notoriety. So it was that as I walked up the landing stage at Bridgetown, a small ebon personality pointed finger at me and confided to his neighbor, "See de mon-de tall mon da-he de mon who chase tree lizards in de cemetry!" "Yes, George," I said, "I'm de mon who chased them with you two years ago, but.this time we shall catch them as well."

"Anyting you say true, Boss, I'se yo boy."

But as is always true in sport, certainty robs it of the finest element of excitement, and our successful stalks that afternoon with grass stem nooses were less memorable than the frantic tree circlings and grave hurdlings of two years before.

On our return from the cemetery a breeze swept up from the sea, the palm fronds slithered against one another, and I suddenly caught myself shivering. The moment I became conscious of this I thought of fever and wondered if my life-long immunity had come to an end. Then I observed old hags wrapping themselves up; my 
eyes suddenly readjusted, I perceived that the glaring sunlight was tempered; again the strange mid-day breeze arose and finally I realized that I was witnessing an eclipse of the sun on the island of Barbados. The natives and the birds and even the patient little donkeys grew restless, the light became weaker and strange, and until the end of the eclipse we could think of nothing else. The most remarkable part to me, were the reflections. Looking however hastily and obliquely at the sun, I perceived nothing but a blinding glare, but walking beneath the shade of dense tropical foliage, the hosts of specks of sunlight sifting through, reflected on the white limestone, were in reality thousands of tiny representations of the sun's disk incised with the segment of the silhouetted moon, but reversed, just like the image through the aperture of a pinhole camera. I suppose it is a very common physical phenomenon, but to me it was a surprising thing to trace the curve of the eclipse clearly and with ease in the sunbeams on the pavement beneath my feet, while my retinas refused to face or register the original.

Barbados is very flat, thoroughly cultivated 
and said to be the most densely populated bit of land in the world; all of which guide-book gossip was discouraging to a naturalist. But besides the cemetery which was sanctuary for the jolly little lizards, I found a bit of unspoilt beach, with sand as white and fine as talcum powder, where dwelt undisturbed many assemblages of small folk. There were land-crabs which had come to have at heart more affection for the vegetable gardens at the beach top than for the waters of their forefathers. They had degenerated into mere commuters from their holes to the nearest melon patch. The lower part of the beach was that ever changing zone - that altar upon which each tide deposited some offering from the depths of the sea. This will some day have a worthy interpreter, a sympathetic recorder and commentator who will make a marvelous volume of this intermittent thread of the earth's surface, pulsing, changing-now showing as water, now as land-but always vital with exciting happenings.

I sat for an hour on the upper beach and watched the little native folk, autochthones who for innumerable generations had been so loyal to their arenaceous home that the sheltering mantle 
of its pale hue had fallen upon their wings and bodies. Here were tiny, grayish-white crabs, here were spiders, which, until they moved, were not spiders but sand. And when they did move, recognition usually came too late to some fly, which had trespassed on this littoral hunting ground. Tiger-beetles drifted about like sand-grain wraiths, whose life wanderings lay between low tide and the highest dune; veriest ghosts of their brilliant green brethren farther inland. Ashen wasps buzzed past, with compass and maps in their heads, enabling them to circle about once. or twice, alight, take a step or two and, kicking down their diminutive front door, to enter the slanting sandy tube which for them fulfilled all the requirements of home.

From an aeroplane, Barbados would appear like a circular expanse of patchwork, or a wild futurist painting set in deepest ultramarine; a maze of rectangles or squares of sugar-cane, with a scattering of sweet potatoes and sea island cotton. I got a hint of this when I motored to the highest point of land, and then climbed the steeple of the loftiest church. At my feet was the Atlantic with great breakers, 
reduced by distance to tiny wavelets twinkling among the black boulders and feathery palms which were scattered along shore. For more than two hundred and seventy-five years the church had stood here, and not to be outdone by the strangeness of the little beach people, the graveyard boasted the remains of a descendant of a Greek Emperor, who long ago had been warden.

But again our steamer summoned us and we left the dusky natives with their weird legends and the tiny island which they love, and were rowed steadily out beyond the two miles of shallow coast.

When we steamed away from shore that night, no lights except those of the dining saloon were allowed. Yet the path of the vessel made a mockery of this concealment. The world did not exist a hundred feet away from the ship and yet there was no mist or fog. The outward curve of the water from the bow was a long slender scimitar of phosphorescence, and from its cutting edge and tip flashed bits of flame and brilliant steely sparks, apparently suspended above the jet-black water. Alongside was a steady ribbon of dull green lumi- 
nescence, while, rolling and drifting along through this path of light came now and then great balls of clear, pure fire touched with emerald flames, some huge jelly or fish, or sargasso weed incrusted with noctiluca. Everywhere throughout the narrow zone of visibility were flickering constellations, suns and planets of momentary life, dying within the second in which they flashed into sight. Once Orion left a distinct memory on the retina-instantly to vanish forever. Perhaps to some unimaginably distant and unknown god, our world system may appear as fleeting. To my eyes it seemed as if I looked at the reflections of constellations which no longer swung across the heavens -shadows of shadows.

Then four bells struck-silveryly-and I knew that time still existed. 


\section{THE POMEROON TRAIL}

RAM NARINe gave a party. It was already a thing of three months past, and it had been an extremely small party, and Ram Narine was only a very unimportant coolie on the plantation of the Golden Fleece. But, like many things small in themselves, this party had farflung effects, and finally certain of these reached out and touched me. So far as I was concerned the party was a blessing. Because of it I was to travel the Pomeroon Trail. But it befell otherwise with Ram Narine.

It was, as I have said, a small party. Only two friends had been invited, and Ram and his companions had made very merry over a cooked cock-fowl and two bottles of rum. In the course of the night there was a fracas, and the face of one of Ram's friends had been somewhat disfigured, with a thick club and a bit of rock. He spent two months in the hospital, and 
eventually recovered. His injuries did not affect his speech, but, coolie-like, he would give little information as to his assailant.

And now the majesty of the law was about to inquire into this matter of Ram's party, and to sift to the uttermost the mystery which concerned the cooked cock-fowl and the rum, and the possibilities for evil which accrued to the sinister club and the bit of rock. I was invited to go, with my friends the Lawyer and the Judge, and our route lay from Georgetown westward, athwart two mighty Guiana rivers.

My mission to British Guiana was to find some suitable place to establish a Tropical Research Station, where three of us, a Wasp Man, an Embryo Man, and a Bird Man, all Americans, all enthusiastic, might learn at first-hand of the ways and lives of the wilderness creatures. After seven years of travel and bird-study in far distant countries, I had turned again to Guiana, the memory of whose jungles had never left me. In New York I had persuaded the powers of the Zoölogical Society that here lay a new, a worthy field of endeavor, hidden among the maze of water-trails, deep in the heart of the forests. For these were forests 
whose treasury of bird and beast and insect secrets had been only skimmed by collectors. The spoils had been carried to northern museums, where they were made available for human conversation and writing by the conferring of names by twentieth-century Adams. We had learned much besides from these specimens, and they had delighted the hearts of multitudes who would never have an opportunity to hear the evening cadence of the sixo'clock bee or the morning chorus of the howling monkeys.

But just as a single photograph reveals little of the inception, movement and dénouement of an entire moving-picture reel, so an isolated dead bird can present only the static condition of the plumage, molt, and dimensions at the instant before death. I am no nature sentimentalist, and in spite of moments of weakness, I will without hesitation shoot a bird as she sits upon her eggs, if I can thereby acquire desired information. But whenever possible, I prefer, for my own sake as well as hers, to prolong my observations, and thus acquire merit in the eyes of my fellow scientists and of Buddha.

I hoped the Pomeroon might prove such a 
desirable region, and fulfil my requirements to the extent that I might call it home for a season. So I accepted the invitation with a double pleasure, for I already knew what excellent company were friends Lawyer and Judge. As a site for my researches the Pomeroon failed; as an experience filled to the brim with interest and enjoyment, my visit left nothing to be desired.

Besides, I met Ram.

The big yellow kiskadees woke me at daybreak; my bedroom wren sang his heart out as I splashed in my shower; and before breakfast was over I heard the honking of my host's car. We glided over the rich red streets in the cool of early morning, past the thronged and already odoriferous market, and on to the tiny river ferry.

This was on Monday, but Ram Narine was to have yet another day of grace, by a twist in the nexus of circumstance which envelops all of us. The Lawyer's orderly had failed to notify his cabman that the Georgetown steamer left at six-fifty instead of seven. So when we finally left the stelling, with a host of twittering martins about us, it was with sorrowful 
faces. Not only were the master's wig and gown missing, besides other articless less necessary from a legal point of view, but the ham for luncheon was lacking. The higher law of compensation now became active, and the day of postponement gave me the sight of the Pomeroon Trail. This delay solved the matter of the wig and gown, and the ham was replaced by a curry equal to a Calcutta cook's best. 'This was served in the Colony House at Suddy Village, where one ate and slept in full enjoyment of the cool tradewind which blew in from the clear stretch of the Atlantic. And here one sat and read or listened to the droning of the witnesses in the petty cases held by the local magistrate in the courtroom below stairs.

I chose to do none of these things, but walked to the sandy beach and along it in the direction of the distant Spanish Main. It was a barren beach, judged by the salvage of most beaches; few shells, little seaweed, and the white sand alternating with stretches of brown mud. I walked until I came to a promontory and, amid splashing muddy waves, climbed out and perched where I ever love to be-on the outermost isolated pile of an old wharf. Scores of 


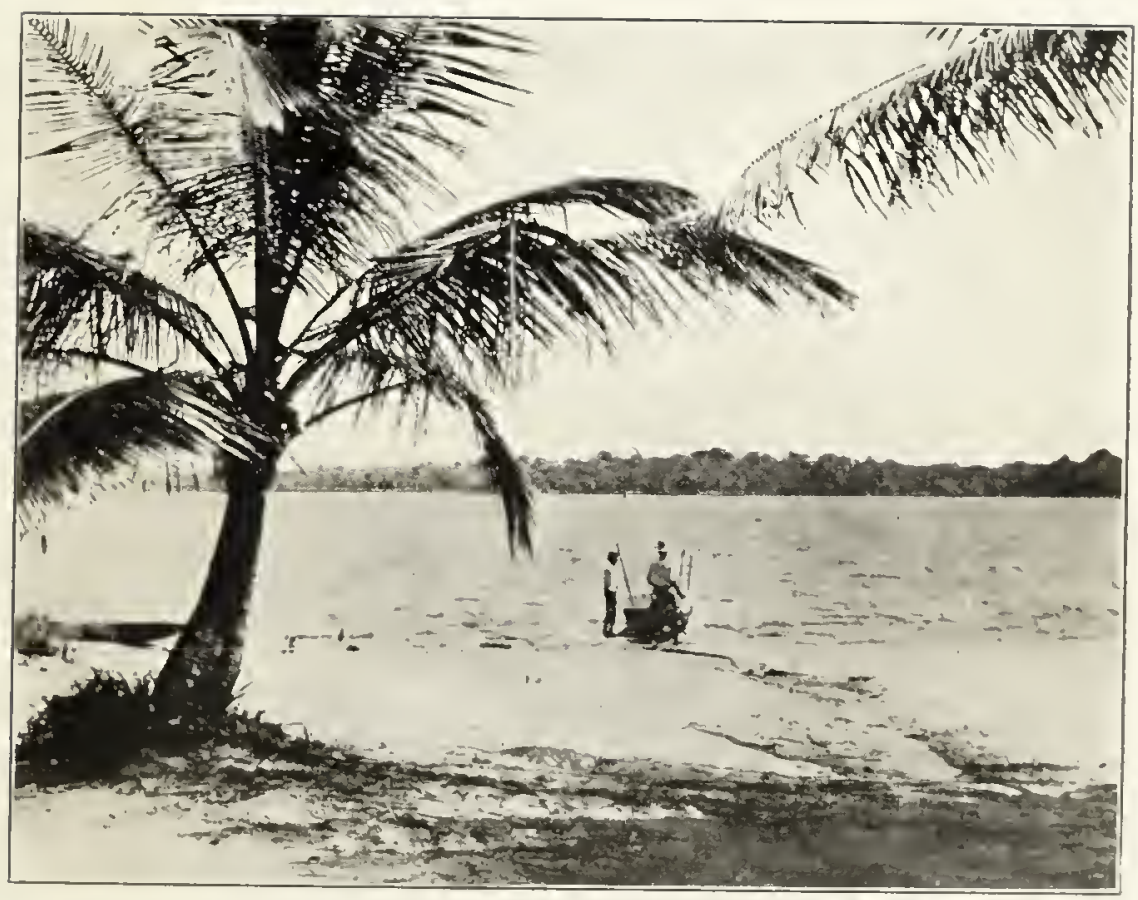

A Guiana Shore 

years must have passed since it was in use, and I tried to imagine what things had come and gone over it. Those were the days of the great Dutch sugar-plantations, when plantations were like small kingdoms, with crowds of slaves, and when the rich amber crystals resembled golddust in more than appearance. What bales of wondrous Dutch lace and furniture and goodies were unloaded from the old high-pooped sailing ships, and what frills and flounces fluttered in this same tradewind, what time the master's daughter set forth upon her first visit to the Netherlands! Now, a few rotted piles and rows of precise, flat Dutch bricks along the foreshore were all that was left of such memories. Inland, the wattled huts of the negroes had outlasted the great manor-houses.

Out at sea there was no change. The same muddy waves rose but never broke; the same tidal current swirlcd and eddied downstream. And now my mind became centered on passing débris, and in a few minutes I realized that, whatever changes had ruffled or passed over this coastal region of Guiana, the source of the muddy waters up country was as untouched now as when Amerigo Vespucci sailed along this 
coast four hundred and twenty years ago. I forgot the shore with its memories and its present lush growth and heat. For in the eddies of the wharf piles swirled strange things from the inland bush. First a patch of coarse grass, sailing out to sea, upright and slowly circling. On the stems I could distinguish unwilling travelers-crickets, spiders, and lesser wingless fry. Half-hollow logs drifted past, some deep and water-soaked, others floating high, with their upper parts quite dry. On such a one I saw a small green snake coiled as high as possible, and, serpent-like, waiting quietly for what fate should bring.

And now came an extraordinary sight-another serpent, a huge one, a great water-constrictor long dead, entangled in some brush, half caught firm and half dangling in the water. Attending were two vultures, ravenous and ready to risk anything for a meal. And they were risking a good deal, for each time they alighted, the brush and snake began to sink and allowed them time for only one or two frantic pecks before they were in water up to their bodies. They then had laboriously to take to flight, beating the water for the first few 
strokes. For several minutes one loop of the snake became entangled about a sunken pile, and now the scavengers boldly perched in the shallow water and fairly ducked their heads at each beakful. Next came a white ants' nest on a lichened trunk, with a multitude of the owners rushing frantically about, scores of them overrunning the confines of their small cosmos, to the great profit and delectation of a school of little fish which swam in the wake.

Most pitiful of all was a tiny opossum, with a single young one clinging tightly about her neck, which approached as I was about to leave. She was marooned on a hollow log which revolved in an arc while it drifted. As it turned, the little mother climbed, creeping first upward, then turning and clambering back, keeping thus ever on the summit. 'The tail of the baby was coiled about her mouth, and he was clinging with all his strength. It was a brave fight and well deserved success. No boat was in sight, so I could not hesitate, but, pulling off my shoes, I waded out as far as I could. At first I thought I must miss it, for I could not go in to my neck even for an opossum. But the wind helped; one or two heavy waves lapped conveniently against 
the sodden bark, and I succeeded in seizing the stub. As I reached for the little creature, the young opossum gave up and slipped into the water, and a ripple showed where a watchful fish had snapped it up. But I got hold of the mother's tail, and despite a weak hiss and a perfunctory showing of teeth, I lifted her and waded ashore. The last view I had, showed her crawling feebly but steadily along a branch into the heart of a dense thicket.

I climbed back to my outpost and dried my clothes in the sun, meditating on the curious psychology of a human which wanted opossums and would unhesitatingly sacrifice a score of opossums for a real scientific need, and yet would put itself to much discomfort to save a single one from going out to sea. Sentimental weakness is an inexplicable thing, and I finally made up my mind-as I always do-not to yield again to its promptings. In fact, I half turned to go in search of my specimen-and then didn't.

The tide had reached full ebb and the sun was low when I started back, and now I found a new beach many feet farther out and down. Still no shells, but a wonderful assortment of 
substitutes in the shape of a host of nuts and seeds-flotsam and jetsam from far up-river, like the snake and ants and opossum. There were spheres and kidney-shapes, half-circles and crescents, heads of little old men and pods like scimitars, and others like boomerangs. Some were dull, others polished and varnished. They were red and green, brown and pink and mauve, and a few gorgeous ones shaded from salmon into the most brilliant orange and yellow. Most were as lifeless in appearance as empty shells, but there were many with the tiny root and natal leaves sprouting hopefully through a chink. And just to be consistent, I chose one out of the many thousands piled in windrows and carried it high up on the shore, where I carefully planted it. It was a nut unknown to me at the time, but later I knew that I had started one of the greatest of the jungle trees on its way to success.

Ahead of me two boys dashed out of the underbrush and rushed into the waves. After swimming a few strokes they reached a great log and, heading it inward, swam it ashore and tied a rope to it. Here was a profession which appealed to me, and which indeed I had already 
entered upon, although the copper-skinned coolie boys did not recognize me as one of their guild. And small blame to them, for I was an idler who had labored and salvaged a perfectly good opossum and the scion of a mighty mora for naught. Here I was, no richer for my walk, and with only damp clothing to show for my pains. Yet we grinned cheerfully at each other as I went by, and they patted their log affectionately as they moored it fast.

Dusk was not far away when I reached Colony House and the Lawyer and I fared forth to seek a suit of pajamas. For the orderly had with him both luxuries and necessities, and so we went shopping. I may say at once that we failed completely in our quest, but, as is usually the case in the tropics, we were abundantly compensated.

We visited emporiums to the number of three,-all that the village could boast,-and the stare of the three Chinawomen was uniformly blank. They could be made in three days, or one could send to Georgetown for most excellent ones; we could not make clear the pressure of our need. The Lawyer grumbled, but the afterglow was too marvelous for any- 
thing to matter for long. Indeed, things wonderful and strange, pathetic and amusing -were so numerous and so needful of all our faculties, that at one time my mind blurred like an over-talked telephone wire. My enthusiasm bubbled over and the good-natured Lawyer enjoyed them as I did.

Here were two among the many. There was the matter of the poor coolie woman who had injured a leg and who, misunderstanding some hastily given order, had left the hospital and was attempting to creep homeward, using hands and arms for crutches. Her husband was very small and very patient and he had not the strength to help her, although now and then he made an awkward attempt. While we sent for help, I asked questions, and in half-broken English I found that they lived six miles away. I had passed them early in the afternoon on the way to the beach, and in the intervening four hours they had progressed just about two hundred feet! This was patience with a vengeance, and worthy of compute. So, astronomer-like, I took notebook and pencil and began to estimate the time of their orbit. It was not an easy matter, for mathematics is to me the least of earth's 
mercies-and besides, I was not certain how many feet there were in a mile. By saying it over rapidly $I$ at last convinced myself that it was " fivethousantwohunderaneighty."

I gasped when I finished, and repeated my questions. And again came the answers: "Yes, sahib, we go home. Yes, sahib, we live Aurora. Yes, sahib, we go like this ver' slow. No, sahib, have no food." And as he said the last sentence, a few drops of rain fell and he instantly spread his body-cloth out and held it over the sick woman. My mind instinctively went back to the mother opossum and her young. The coolie woman ceaselessly murmured in her native tongue and looked steadily ahead with patient eyes. Always she fumbled with her dusty fingers for a spot to grip and shuffle ahead a few inches.

Two hundred feet in four hours! And six full miles to the coolie quarters! This was on the fourteenth of a month. If my calculation was correct they would reach home on the tenth of the following month, in three weeks and five days. Truly oriental, if not, indeed, elemental patience! This planet-like journey was deviated from its path by a hospital stretcher and a swift 
return over the four-hour course, although this cosmic disturbance aroused comment from neither the man nor his wife. I checked off another helpless being salvaged from the stream of ignorance.

From serio-comic tragedy the village street led us to pure comedy. At the roadside we discovered a tiny white flag, and beneath it a bit of worn and grimy cloth stretched between a frame of wood. This was a poster announcing the impending performance of one "Profesor $\mathbf{R a -}$ bintrapore," who, the painfully inked-in printing went on to relate, "craled from ankoffs" and "csskaped from cofens," and, besides, dealt with "spirits INvisibal." The professor's system of spelling would have warmed the heart of our modern schoolteachers, but his séances did not seem to be tempting many shekels from the pockets of coolie spiritualists.

After tea at the Colony House, I leaned out of my window and watched the moonlight gather power and slowly usurp the place of the sun. Then, like the succession of light, there followed sound: the last sleepy twitter came from the martin's nest under the eaves, and was sustained and deepened until it changed 
to the reverberating bass rumble of a great nocturnal frog.

In the moonlight the road lay white, though I knew in the warm sun it was a rich, foxy red. It vanished beyond some huts, and I wondered whither it went and remembered that tomorrow I should learn for certain. Then a ghostly goatsucker called eerily, "Who-areyou?" and the next sound for me was the summons to early coffee.

During the morning the missing orderly arrived, and with him the wig and gown and the ham. And now the matter of Ram Narine became pressing, and my friends Lawyer and Judge became less human and increasingly legal. I attended court and was accorded the honor of a chair between a bewigged official and the Inspector of Police, the latter resplendent in starched duck, gold lace, spiked helmet, and sword. Being a mere scientist and wholly ignorant of legal matters, I am quite like my fellow human beings and associate fear with my ignorance. So under the curious eyes of the black and Indian witnesses and other attendants, I had all the weaving little spinal thrills which one must experience on being, or being about to 
be, a criminal. There was I betwixt law and police, and quite ready to believe that I had committed something or other, with malicious or related intent.

But my thoughts were soon given another turn as a loud rapping summoned us to our feet at the entrance of the Judge. A few minutes before, we had been joking together and companionably messing our fingers with oranges upstairs. Now I gazed in awe at this impassive being in wig and scarlet vestments, whose mere entrance had brought us to our feet as if by religious or royal command. I shuddered at my memory of intimacies, and felt quite certain we could never again sit down at table as equals. When we had resumed our seats there was a stir at the opposite end of the courtroom, and a half-dozen gigantic black policemen entered, and with them a little, calm-faced, womanly man-Ram Narine, the wielder of the club and the rock. He ascended to the fenced-in prisoners' dock, looking, amid all his superstrong barriers to freedom, ridiculously small and inoffensive, like a very small puppy tethered with a cable. He gazed quietly down at the various ominous exhibits. $\mathrm{A}$ and $\mathrm{B}$ were the club and 
the rock, with their glued labels reminding one of museum specimens. Exhibit $\mathrm{C}$ was a rumbottle-an empty one. Perhaps if it had been full, some flash of interest might have crossed Ram's face. Then weighty legal phrases and accusations passed, and the Judge's voice was raised, sonorous and impressive, and I felt that nothing but memory remained of that jovial personality which I had known so recently.

The proceeding which impressed me most was the uncanny skill of the official interpreter, who seemed almost to anticipate the words of the Judge or the Clerk. And, too, he gestured and shook his finger at the prisoner at the appropriate places, though he had his back fairly to the Judge and so could have had none but verbal clues. Ram Narine, it seems, was indicted on four counts, among which I could distinguish only that he was accused of maltreating his friend with intent to kill, and this in soft Hindustani tones he gently denied. Finally, that he had at least done the damage to his friend's face and very nearly killed him. To this he acquiesced, and the Court, as the Judge called himself, would now proceed to pass sentence. I was relieved to hear him thus re- 
name himself, for it seemed as if he too realized his changed personality.

And now the flow of legal reiteration and alliteration ceased for a moment, and I listened to the buzzing of a marabunta wasp and the warbling of a blue tanager among the fronds. For a moment, in the warm sunshine, the hot, woolly wigs and the starched coats and the shining scabbard seemed out of place. One felt all the discomfort of the tight boots and stiff collars, and a glance at Ram Narine showed his slim figure clothed in the looped, soft linen of his race. And he seemed the only wholly normal tropic thing there-he and the wasp and the tanager and the drooping motionless palm shading the window. In comparison, all else seemed almost Arctic, unacclimatized.

Then the deep tones of the Court rose, and in more simple verbiage,-almost crude and quite unlegal to my ears, - we heard Ram Narine sentenced to twelve months' hard labor. And the final words of the interpreter left Ram's face as unconcerned and emotionless as that of the Buddhas in the Burmese pagodas. And the simile rccurred again and again after it was all over. So Ram and I parted, to meet 
again a few weeks later under strangely different conditions.

Robes and wigs and other legal properties were thrown aside, and once more we were all genial friends in the little automobile, with no trace of the terribly formal side of justice and right. The red Pomeroon road slipped past, and I, for one, wished for a dozen eyes and a score of memories to record the unrolling of that road. It was baffling in its interest.

The first ten or twenty miles consisted of huge sugar estates, recently awakened to feverish activity by the war prices of this commodity. Golden Fleece, Taymouth Manor, Capoey, More Success, Anna Regina, Hampton Court -all old names long famous in the history of the colony. In many other districts the Dutch have left not only a heritage of names, such as Vreeden-Hoop and Kyk-over-al, but the memory of a grim sense of humor, as in the case of three estates lying one beyond the other, which the owners named in turn, Trouble, More Trouble, and Most Trouble. Unlike our southern plantations, the workers' quarters are along the road, with the big house of the manager well back, often quite concealed. The 
coolies usually live in long, communal, barracklike structures, the negroes in half-open huts.

This first part of the Pomeroon road was one long ribbon of variegated color: Hundreds of tiny huts, with picturesque groups of coolies and negroes and a smaller number of Chinese, all the huts dilapidated, some leaning over, others so perforated that they looked like the ruins of European farmhouses after being shelled. Patched, propped up, tied together, it was difficult to believe that they were habitable. All were embowered in masses of color and shadowed by the graceful curves of cocoanut palms and bananas. The sheets of bougainvillea blossoms, of yellow allamandas, and the white frangipani temple flowers of the East, brought joy to the eye and the nostril; the scarlet lilies growing rank as weeds-all these emphasized the ruinous character of the huts. Along the front ran a trench, doubling all the glorious color in reflection, except where it was filled with lotus blossoms and Victoria regia.

As we passed swiftly, the natives rushed out on the shaky board-and-log bridges, staring in wonder, the women with babies astride of their 
hips, the copper-skinned children now and then tumbling into the water in their excitement. The yellows and reds and greens of the coolies added another color-note. Everything seemed a riot of brilliant pigment. Against the blue sky great orange-headed vultures balanced and volplaned; yellow-gold kiskadees shrieked blatantly, and, silhouetted against the green fronds, smote both eye and ear.

We were among the first to pass the road in an automobile. Awkward, big-wheeled carts, drawn by the tiniest of burros and heaped high with wood, were the only other vehicles. For the rest, the road was a Noah's Ark, studded with all the domestic animals of the world: pigs, calves, horses, burros, sheep, turkeys, chickens, and hordes of gaunt, pariah curs. Drive as carefully as we might, we left behind a succession of defunct dogs and fowls. For the other species, especially those of respectable size, we slowed down, more for our sake than theirs. Calves were the least intelligent, and would run ahead of us, gazing fearfully back, first over one, then the other shoulder, until from fatigue they leaped into the wayside ditch. The natives themselves barely moved aside, and why 


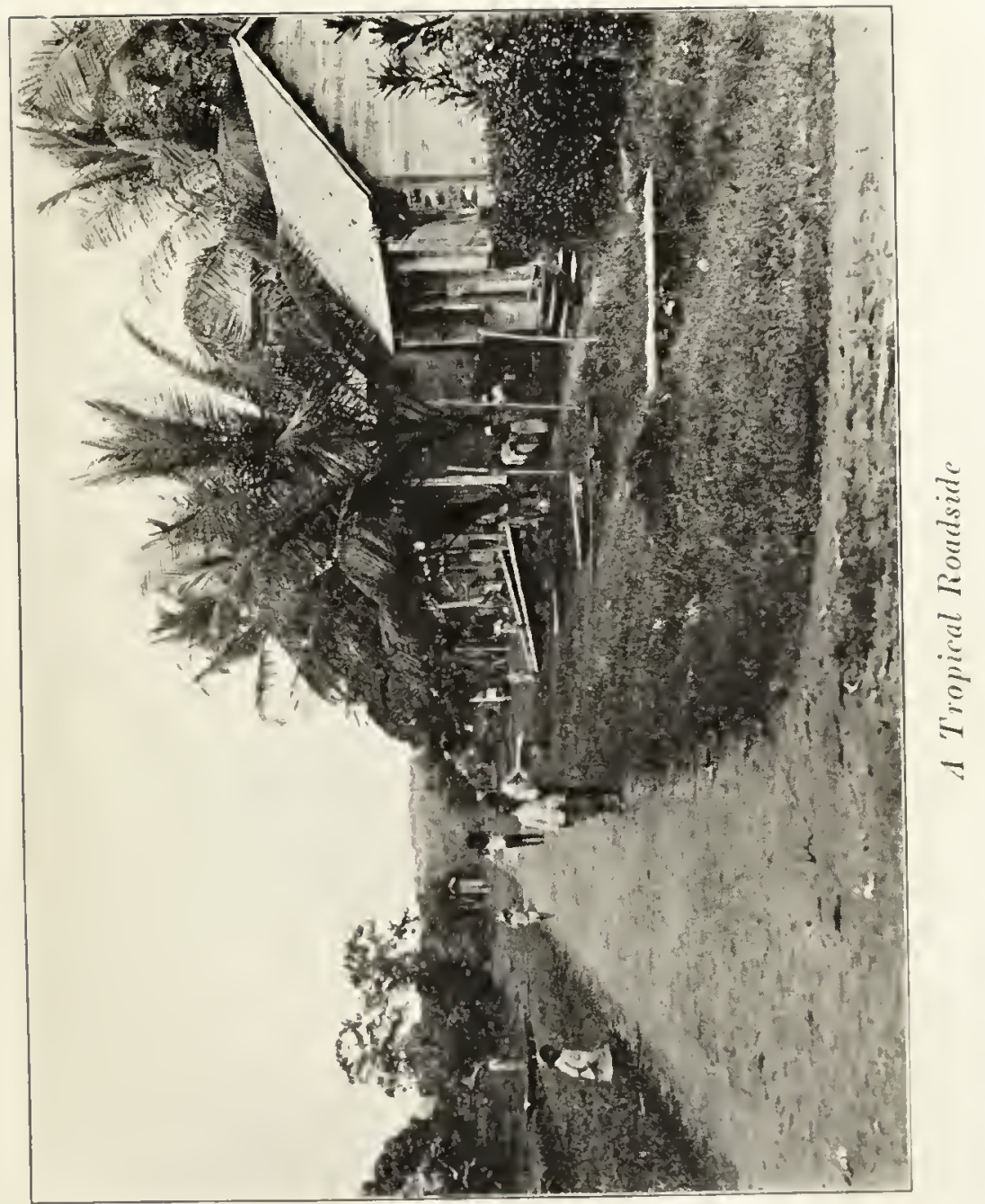



we did not topple over more of the great headcarried loads I do not know. We left behind us a world of scared coolies and gaping children.

The road was excellent, but it twisted and turned bewilderingly. It was always the same rich red hue-made of earth-clinker burned under sods. Preparing this seemed a frequent occupation of the natives, and the wood piles on the carts melted away in the charcoal-like fires of these subterranean furnaces. Here and there tiny red flags fluttered from tall bamboo poles, reminiscent of the evil-spirit flags in India and Burma. But with the transportation across the sea of these oriental customs certain improvements had entered in,-adaptations to the gods of ill of this new world. So the huts in course of alteration, and the new ones being erected, were guarded, not only by the fluttering and the color, but by a weird little figure of a dragon demon himself drawn on the cloth, a quite unoriental visualizing of the dreaded one.

As we flew along, we gradually left the villages of huts behind. Single thatched houses were separated by expanses of rice-fields, green rectangles framed in sepia mud walls, picked 
out here and there by intensely white and intensely Japanesque egrets. Great black muscovy ducks spattered up from amber pools, and tri-colored herons stood like detached shadows of birds, mere cardboard figures, so attenuated that they appeared to exist in only two planes of space.

The rice-fields gave place to pastures and these to marshes; thin lines of grass trisected the red road-the first hint of the passing of the road and the coming of the trail. Rough places became more frequent. Then came shrub, and an occasional branch whipped our faces. Black cuckoos or old witch-birds flew up like disheveled grackles; cotton-birds flashed by, and black-throated orioles glowed among the foliage. Carrion crows and laughing falcons watched us from nearby perches, and our chauffeur went into second gear.

Now and then some strange human being passed,-man or woman, we could hardly tell which,-clad in rags which flapped in the breeze, long hair waving, leaning unsteadily on a staff, like a perambulating scarecrow. The eyes, fixed ahead, were fastened on things other than those of this world, so detached that their first sight 
of an automobile aroused them not at all. The gulf between the thoughts of these creatures and the world today was too deep to be bridged by any transient curiosity or fear. They trudged onward without a glance, and we steered aside to let them pass.

The grass between the ruts now brushed the body of the car; even the wild people passed no more, and the huts vanished utterly. Forest palms appeared, then taller brush, and trees in the distance. Finally, the last three miles became a scar through the heart of the primeval jungle, open under the lofty sky of foliage, the great buttresses of the trunks exposed for the first time to the full glare of day. The trail was raw with all the snags and concealed roots with which the jungle likes to block entrance to its privacy; and, rocking and pitching like a ship in the waves, we drew up to a woodpile directly in our path. Standing up in our seats, we could see, just beyond it, the dark flood of the Pomeroon surging slowly down to the sea. Seven years ago I had passed this way en route from Morawhanna, paddled by six Indians. Maintenant ce n'est qu'une mémoire.

For centuries the woodskins of the Indians 
had passed up and down and left no trace. Only by this tidal road could one reach the mouth of tributaries. And now the sacred isolation of this great tropical river was forever gone. The tiny scar along which we had bumped marked the permanent coming of man. And his grip would never relax. Already capillaries were spreading through the wilderness tissues. Across the river from our woodpile were two tiny Portuguese houses-those petty pioneers of today whose forefathers were worldwide explorers. Around us, scarcely separable from the bush, was the coffee plantation of one Señor Serrao. He and his mother greeted us, and with beaming courtesy we were led to their wattled hut, where a timid sister gave us grapefruit. I talked with him of his work and of the passing of the animals of the surrounding forest. Tapir were still common, and the wild pigs and deer waged war on his regetables. Then a swirl drew our eyes to the brown flood and he said, "Perai."

And this was the end of the tropical trail which had started out as a road, with its beginning, for me, in the matter of Ram Narine. Along its route we had passed civilization as 
men know it here, and had seen it gradually fray out into single aged outcasts, brooding on thoughts rooted and hidden in the mystery of the Far East. From the water and the jungle the trail had rouchsafed us glimpses and whispers of the wild creatures of this great continent, of the web of whose lives we hoped to unravel a few strands. The end of the trail was barred with the closed toll-gate of memory. 


\section{$\checkmark$ \\ A HUNT FOR HOATZNS}

LMEs of gras. plunging tropic rain slanted across the whole world. Outward-curring Tares of red mud lost themselres in the steady dompour berond the guards on the motor-car of the Inspector of Police. It is surprising to think how mant times and in what a multitude of places I hare been indebted to inspectors of police. In New York the arerage risitor would never think of meeting that official except under extraordinary and perhaps compromising circumstances: but in tropical British possessions the head of the police combines with his requisite large quantity of gold lace and tact a delightful way of placing risitors, and especialls those of serious scientific intent, under considerable obligation. So m! present Inspector of Police, at an official banquet the preceding erening, had insisted that I trarel along the seafront of 
Guiana-betwixt muddy salt water and canefields-in his car. But an inspector of police is not necessarily a weather prophet, and now the close-drawn curtains forbade any view, so it was decided that I tranship to the single daily train.

Three times I had to pass the tichet-collector at the station to see after my luggage, and three times a large clorer-leaf was punched out of my exceedingly small bit of pasteboard. A can of formaline still eluded me, but I looked dubiously at my limp trey of clubs. Like a soggy gingersnap, it drooped with its omn weight, and the chances seemed about eren whether another trip past the hopelessly conscientious coolie gateman would find me with a totally dismembered ticket or an asymmetrical four of clubs of lacelike consistencr. I forebore, and walking to the end of the platform, looked out at a long line of feathery cocoanut palms, pasteled by the intervening rain. Ther. were silhouetted in a station aperture of corrugated iron, of all building materials the most hideous; but the aperture was of that most graceful of all shapes, a Moorish arch.

Neither my color nor $m y$ caste, in this ultrademocratic country, forced me to travel first- 
class, but that necessary, unwritten distinction, felt so keenly wherever there is a mingling of race, compelled me to step into a deserted car upholstered in soiled dusty blue. I regretted that I must "save my face," as a Chinaman would say, and not sit on the greasy bare boards of the second-class coach, where fascinating coolie persons sat, squatting on the seats with their heads mixed up with their knees. Desire, prompted by interest and curiosity, drew me to them, and frequently I got up and walked past, listening to the subdued clink of silver bracelets and anklets, and sniffing the wisps of ghee and curry and hemp which drifted out. Nose-rings flashed, and in the dim station light I caught faint gleams of pastel scarves-sea-green and rose. I longed for Kim's disguise, but I knew that before many stations were passed the concentration of mingled odors would have driven me back to my solitude. Perhaps the chief joy of it all lay in the vignettes of memory which it aroused: that unbelievable hot midnight at Agra; the glimpse of sheer Paradise in a sunrise on the slopes of Kinchinjunga; the odors of a caravan headed for the Khyber Pass.

When I returned to my coach I found I was 
to have company. A stout-no, exceedingly fat -bespectacled gentleman, with pigment of ebony, and arrayed in full evening dress and high hat, was guarding a small dilapidated suitcase, and glaring at him across the aisle was a man of chocolate hue, with the straight black hair of the East Indian and the high cheekbones and slanting eyes of the Mongolian. His dress was a black suit of heavy Scotch plaid, waistcoat and all, with diamonds and loud tie, and a monocle which he did not attempt to use. Far off in the distant corner lounged a bronzed planter in comfortable muddy clothes. But we three upheld the prestige of the west end of the carriage.

Soon, impelled by the great heat, I removed my coat and was looked at askance; but I was the only comfortable one of the three. With the planter I should have liked to converse, but with those who sat near I held no communication. I could think of them only as insincere imitators of customs wholly unadapted to their present lives and country. I could have respected them so much more if they had clad themselves in cool white duck. I hold that a man is not worth knowing who will endure ex- 
cessive tropical heat, perspiring at every pore, because his pride demands a waistcoat and coat of thickest woolen material, which would have been comfortable in a blizzard. So I went out again to look at the coolies with their honest garb of draped linen, and they seemed more sincere and worthy of acquaintance.

We started at last, and only a few miles of glistening rails had passed beneath us when, finally, proof of the complete schism between police and weather bureaus became evident: the fresh tradewind dispersed the rain! The clouds remained, however-low, swirling masses of ashy-blue, billowing out like smoke from a bursting shell, or fraying in pale gray tatters, tangling the fronds of lofty palms. For the rest of the day the light came from the horizon-a thrillingly weird, indirect illumination, which lent vividness and intensity to every view. The world was scoured clean, the air cleansed of every particle of dust, while the clouds lent a cool freshness wholly untropical, and hour after hour the splendid savannah lands of the coast of Guiana slipped past, as we rumbled swiftly southward along the entire shore-front. 
At first we passed close to the sea, and this was the most exciting part of the trip. In places the dikes had given way and the turbulent muddy waters had swept inland over rice and cane-fields, submerging in one implacable tide the labor of years. A new dike, of mud and timbers and sweet-smelling hurdles of black sage, had been erected at the roadside, and past this went all traffic. Now and then an automobile had to slow up until a great wave broke, and then dash at full speed across the danger-spot. In spite of the swiftness, the wind-flung spray of the next wave would drench the occupants. The lowering sea-water glistened among the sickly plants, and strange fish troubled the salty pools as they sought uneasily for an outlet to the ocean. A flock of skimmers looked wholly out of place driving past a clump of bamboos.

Then the roadbed shifted inland, and lines of patient, humped zebus trailed slowly from their sheds-sheds of larger size and better built than the huts of their owners. These openwork homes were picturesque and unobtrusive; they fitted into the landscape as if, like the palms, they had come into being through years 
of quiet assimilation of water and warmth. Their walls were of mud, adobe, mere casual upliftings of the sticky soil which glistened in every direction. Their roofs were of troolypalm fronds, brown and withered, as though they had dropped from invisible trees high overhead. Like the coolies themselves, the houses offered no note of discord.

I had just come from the deep jungle of the interior with its varying lights and shadows, its myriad color-grades, pastel, neutral in quality. Here was boldness of stroke, sharpness of outline, strength of pigment. All the dominant tones of this newly washed coastal region were distinct and incisive. Clear-cut silhouettes of vultures and black witch-birds were hunched on fence-posts and shrubs. Egrets, like manikins cut from the whitest of celluloid, shone as far as the eye could see them. As if the rain had dissolved and washed away every mixed shade and hue, the eye registered only flaming, clashing colors; great flocks of birds black as night, save for a glowing scarlet gorget; other black birds with heads of shining gold, flashing as the filigree nose-beads flash against the rich dark skin of the coolies. 
Like the colors, the sounds were individualized by sharpness of tone, incisiveness of utterance. The violent cries of flycatchers cleft the air, and, swiftly as we passed, struck on my ear fair and strong. The notes of the blackbirds were harmonious shafts of sound, cleaving the air like the whistle of the meadowlark. Hawks with plumage of bright cinnamon and cream, hurled crisp, piercing shrieks at the train. Only the vultures, strung like ebony beads along the fronds of the cocoanut palms, spread their wings to dry, and dumbly craned their necks down as we passed.

Past Mahaica and Abary we rushed, the world about us a sliding carpet of all the emerald tints in the universe. And just as the last tint had been used up and I knew there must be some repetition, the clouds split and a ray of pure sunlight shot through the clear air and lit up a field of growing rice with living green of a still newer hue, an unearthly concentrated essence of emerald which was comparable to nothing but sprouting rice in rain-washed sunlight. Whether this be on the hot coastlands of Java, in tiny sod-banked terraces far up on the slopes of Dehra Dun, or in the shadow of 
Fuji itself, makes no manner of difference. The miracle of color never fails.

Trees were so rare that one was compelled to take notice of them. High above the bamboos, high above even those arboreal towers of Pisa, the cocoanut palms, rose the majestic silk-cotton trees, bare of leaves at this season, with great branches shooting out at breathless heights. Like strange gourd-like fruit, three sizes of nests hung pendant from these lofty boughs: short, scattered purses of yellow orioles, colonied clusters of the long pouches of yellow-backed bunyahs, and, finally, the great, graceful, woven trumpets of the giant black caciques, rarely beautiful, and, like the trees, scarce enough to catch and hold the eye. The groves of cocoanut palms, like a hundred enormous green rockets ever bursting in mid-air, checkered the sunlight, which sifted through and was made rosy by a host of lotus blooms beneath. Then the scene changed in a few yards, and low, untropical shrubs filled the background, while at our feet rose rank upon rank of cat-tails, and we might be passing across the Jersey meadows.

Each little station was the focus of a world of its own. Coolies and blacks excitedly hus- 
tled to place on board their contribution to the world's commerce:-tomatoes no larger than cherries, in beautifully woven baskets; a crate of chickens or young turkeys; a live sheep protesting and entangled in the spokes of an oldfashioned bicycle; a box of fish, flashing silver and old rose. Some had only a single bundle of fodder to offer. At one station, quaintly named De Kinderen, a clear-faced coolie boy pushed a small bunch of plantains into the freight van, then sat on the steps. As the train started to move he settled himself as if for a long ride, and for a second or two closed his eyes. Then he opened them, climbed down, and swung off into the last bit of clearing. His face was sober, not a-smile at a thoughtless lark. I looked at his little back as he trudged toward his home, and wondered what desire for travel, for a glimpse of the world, was back of it all. And I wished that I could have asked him about it and taken him with me. 'This little narrowgauge link with the outside world perhaps scatters heartaches as well as shekels along its right of way.

I was watching a flock of giant anis, which bubbled cheerfully on their slow flight across 
the fields, when a wide expanse of water blocked our way, and we drew up at the bank of the Berbice River.

In the course of five days at New Amsterdam we achieved our object. We found hoatzins, their nests, eggs, and young, and perpetuated in photographs their wonderful habits handed down through all the ages past, from the time when reptiles were the dominant beings, and birds and mammals crept about, understudying their rôle to come, as yet uncertain of themselves and their heritage. When we needed it the sun broke through the rain and shone brightly; when our lenses were ready, the baby hoatzins ran the gamut of their achievements. They crept on all fours, they climbed with fingers and toes, they dived headlong, and swam as skilfully as any Hesperornis of old. This was, and I think always will be, to me, the most wonderful sight in the world. To see a tiny living bird duplicate within a few minutes the processes which, evolved slowly through uncounted years, have at last culminated in the world of birds as we find it today-this is impressive beyond words. No poem, no picture, no terrible danger, no sight of men killed or 
injured has ever affected me as profoundly as this.

Thus the primary object of the trip was accomplished. But that is a poor expedition indeed which does not yield another hundred per cent. in oblique values, of things seen out of the corner of one's eyes.

If one is an official or an accredited visitor to Berbice, the Colony House is placed at one's service. I am sure that it is quite the ugliest of all colony houses, and surrounded by what $\mathbf{I}$ am equally sure is one of the most beautiful of tropical gardens. If Berbice held no other attraction it would be worth visiting to see this garden. The first floor of Colony House is offices, the second is the Supreme Court, and when I peeped in I saw there were three occupants-a great yellow cat curled up in the judge's chair, and two huge toads solemnly regarding each other from the witness-box and the aisle.

Three stories in Guiana constitute a skyscraper, and that night I slept on a level with the palm fronds. It was a house of a thousand sounds. During the day hosts of carpenters tore off uncountable shingles devastated by 
white ants. Two antithetical black maids attended noisily but skilfully to all my wants. At night, cats and frogs divided the vocal watches, and a patient dog never tired of rolling the garbage-can downstairs past the Supreme Court to the first floor. I thought of this at first as some strange canine rite, a thing which Alice could have explained with ease, or which to Seumas and to Slith would have appeared reasonable and fitting. I used to wait for it before I went to sleep, knowing that comparative silence would follow. I discovered later that this intelligent dog had learned that, by nudging the can off the top step, the cover would become dislodged at about the level of the Supreme Court, and from there to the government offices he could spend a night of gastronomic joy, gradually descending to the level of the entrance.

A kind planter put me up at the club, the usual colonial institution where one may play bridge or billiards, drink swizzles, or read war telegrams "delayed in transit." These were the usual things to do, daily duties, timed almost regularly by the kiskadees' frantic farewell to the day or the dodging of the first vampire among the electric-light bulbs. But in this ex- 
citing country, with hoatzins asleep within a half-mile, I could not bring my mind to any of these things, and wandered about, idly turning the leaves of dull periodicals, looking at cases of cues and the unfinished records of past billiard tournaments, yellowed with age. The steward approached timidly.

"Would the sahib like to see the library?"

Yes, the sahib decidedly would. We climbed the stairs, creaking as if they complained at the unaccustomed weight of footsteps, to the upper room of the club. It was large, barnlike in its vacantness, with a few little tables, each surrounded by a group of chairs, like chickens crowded about a hen. The walls were lined with books and there was an atmosphere about the room which took hold of me at once. I could not identify it with any previous experience, certainly not with the libraries of Greorgetown in which I had spent days. This was something subtle, something which had to discover itself. The steward led me proudly about, making it plain that his affection was here rather than with the mixing of swizzles below. No, he had never read any of them, but he would feel honored if $\mathbf{I}$ found any pleasure in them and 
would condescend to borrow one. He seemed rather emphatic on this point; he especially desired that I take one to Colony House. Then he left me.

The books were without a speck of dust, each volume in its place and aligned with precision. Little by little, as I made my round, nibbling at a book here and there, the secret of the place came to me: it was a library of the past, a dead library. There seemed something uncanny, something unreal about it. Here were hundreds of books, there tables and chairs, but no one ever used them. Yet it was in the center of a large town just above the most frequented gatheringplace. More than this the library itself was obsolete. No volume had been added for many years. Most of them were old, old tomes, richly bound in leather and tree calf. Nearly all were strange to me-little-known histories and charmingly naïve "Conversations" and memoirs of generations ago. They were delicately, gracefully worded, many of them; one could feel the lace and velvet of the sleeve which had touched them; the subtle musty odors of the yellowed page and crumbling leather seemed tinged with faint, strange perfumes. It was astounding and 
very affecting, and my interest increased with every minute.

The evening chorus of the tropical night had commenced outside, and a glance out of the window showed a network of motionless fronds dimly outlined against the rose-colored clouds over the waters of the Berbice. Below I heard the soft click of billiard balls. Then I returned to the books. Their rich bindings were falling apart, musty, worm-eaten, many held together only by a string. It was as if I had entered the richly filled library of some old manor-house which had been scaled up for two-score years, and yet kept lovingly dusted. It was this sense of constant care which served to emphasize the weird isolation, the uncanny dcsolation.

I glanced at Lives of the Lindsays, by Lord Lindsay, a work of sixty-five years ago, unknown to me, quaint and delightful. This rubbed covers with Lockhart's Life of Scott. On another shelf I recall The Colloquies of $\boldsymbol{E} d$ roard Osborne, Citizen and Clothmaker of London, which held me until I knew that the Colony House dog would get all of my dinner if $\mathbf{I}$ did not start homewards. The next volume to this 
was a friend, Thier's The C'onsulate and the Empire. Then I walked past stacks of oldfashioned novels, nearly all in three volumes. Their names were strange, and I suppose they would prove deadly reading to our generation; but I am sure that in their day they fascinated many eyes reading by the flickering light of tapers and rushes. And even now they stood bravely alongside Dickens and Scott.

Finally I reached up to the highest row and chose one of a series of heavy tomes whose titles had completely fallen away with age and climate. I untied the binding string, opened at random and read thus:-

"It is vain, then, any longer to insist on variations of organic structure being the result of habits or circumstances. Nothing has been elongated, shortened or modified, either by external causes or internal volition; all that has been changed has been changed suddenly, and has left nothing but wrecks behind it, to advertise us of its former existence."

Thus wrote the Baron Cuvier many years ago. And this brought me back to reality, and my study of those living fossils now asleep in the neighboring bunduri thorn bushes, whose 
nestlings so completcly refute the good baron's thesis.

As I reached the door I selected a volume at random to take back to Colony House. I put out the lights and turned a moment to look about. The platinum wires still glowed dully, and weak moonlight now filled the room with a silver grayness. I wondered whether, in the magic of some of these tropical nights, when the last ball had been pocketed and the last swizzle drunk belowstairs, some of the book-lovers of olden times, who had read these volumes and turned down the crcased pages, did not return and again laugh and cry over them. There was no inharmonious note: no thrilling short storics, no gaudy cliromatic bindings, no slangy terse titles, no magazines or newspapers. Such gentlefolk as came could have sat there and listened to the crickcts and the occasional cry of a distant heron and have been untroubled by the consciousness of any passage of time.

I learned that this Library Club had been the oldest in the West Indies, founded about threc quarters of a century ago. It had long ccased to exist, and no one ever disturbed the quietness of the gradual dissolution of this ad- 
mirable collection of old works. I walked slowly back, thinking of the strange contrast between what I had seen and the unlovely, commercialized buildings along the street. I was startled from my reverie by the challenge of the sentry, and for a moment could not think what to answer. I had well-nigh forgotten my own personality in the vividness of the stately early Victorian atmosphere.

Long after the Colony House dog had noisily announced the beginning of his nocturnal feast, I lay behind my net poring over the Memoirs of the Lady Hester Stanhope, as related by herself in conversations with her physician, comprising her opinions and anecdotes of some most remarkable persons, and I came to the conclusion that by far the most remarkable of them all was Lady Hester herself.

Berbice, we were told by residents elsewhere, was behind the times. I found it up to date, colonially speaking, and, indeed, possessing certain ideas and ideals which might advantageously be dispersed throughout the colony. But New Amsterdam, with all its commercial hardness of outline and sordid back streets, flashed out in strangely atavistic touches now and 
then; a sort of quintessence of out-of-dateness which no inhabitant suspected, and which was incapable of legislative change. First, there were hoatzins, hinting of aons of years ago; then, the library, which preserved so perfectly the atmosphere of our great grandparents. And now, as I left the compound of Colony House in the early morning, I watched with fascination a coolie woman bearing a great bundle of loosely bound fagots on her head. As she walked, they kept dropping out, and instead of leaning down or squatting and so endangering the equilibrium of all the rest, she simply shifted her weight to one foot, and felt about with the other. When it encountered the fallen stick, the big toe uncannily separated and curled about it, and she instantly bent her knce, passed up the stick to her hand and thence to the bundle again. It surpassed anything I had ever seen among savages-the handlike mobility of that coolie woman's toes. And I thought that, if she was a woman of Simla or of the Western Ghats, then my belief in the Siwalik origin of mankind was irrevocable!

It seemed as if I could not escape from the spell of the past. I walked down to a dilapi- 
dated stelling to photograph a mob of vultures, and there found a small circle of fisherfolk cleaning their catch. They were wild-looking negroes and coolies, half-naked, and grunting with the exertion of their work. A glance at the fish again drove me from Berbice.into ages long gone by. Armored catfish they were, reminiscent of the piscine glories of Devonian times - uncouth creatures, with outrageously long feelers and tentacles, misplaced fins, and mostly ensconced in bony armor, sculptured and embossed with designs in low relief. I watched with half-closed eyes the fretted shadows of the palms playing over the glistening black bodies of the men, and the spell of the strange fish seemed to shift the whole scene centuries, tens of centuries, backward.

The fish, attractive in the thought suggested by their ancient armor, were quite unlovely in their present surroundings. Piles of them were lying about in the hot sun, under a humming mass of flies, awaiting their unhurried transit to the general market. When the fishermen had collected a quantity of heads, apparently the chief portions considered inedible, these were scraped off the stelling to the mud 
beneath. At this there arose a monstrous hissing and a whistle of wings, and a cloud of black vultures descended with a rush and roar from surrounding roofs and trees.

While watching and photographing them, I saw an antithesis of bird-life such as $\mathbf{I}$ had never imagined. The score of vultures fought and tore and slid about in the black noisome mud exposed by the low tide. Sometimes they were almost back downward-fairly slithering through the muck to seize some shred of fish, hissing venomously; and at last spreading filthy, mud-dripping pinions to flap heavily away a few paces. In disgust at the sight and sound and odor, I started to turn back, when in the air just above the fighting mass, within reach of the flying mud, poised a hummingbird, clean and fresh as a rain-washed blossom. With cap of gold and gorget of copper, this smallest, most ethereal, and daintiest of birds hung balanced just above the most offensive of avian sights. My day threatened to be one of emotion instead of science.

Berbice vouchsafed one more surprise, a memory from the past which appeared and vanished in an instant. One of the most delightful of 
men was taking me out to where the hoatzins lived. We went in his car, which, and I use his own simile, was as truly a relic as anything $I$ have mentioned. I have been in one-horse shays. I have ridden for miles in a Calcutta gharry. I was now in a one-cylinder knockabout which in every way lived up to its name. It was only after a considerable time that I felt assured that the mud-guards and wheels were not on the point of leaving us. When I had also become accustomed to the clatter and bang of loose machinery I was once more able to look around. I had become fairly familiar with the various racial types of Guiana, and with some accuracy I could distinguish the more apparent strains. Halfway through the town we passed three girls, one a coolie, the second dominantly negroid, while the third showed the delicate profile, the subtle color, the unmistakable physiognomy of a Syrian. She might have posed for the finest of the sculptures on a Babylonian wall. I turned in astonishment to my host, who explained that years ago some Syrian peddlers had come this way, remained, prospered, and sent for their wives. Now their children had affiliated with the other varied types-affiliated 
in language and ideas perhaps, but not, in one case at least, at the expense of purity of facial lineament of race.

As I have said, success with the hoatzins came swiftly and completely. We had discovered a few nests with young birds of just the right age and in positions which left nothing to be desired. Yet when a jovial Scotch manager came with news that one of his coolies knew of colonies of hundreds of breeding anaquas, we decided to take the whole of the proverbial cake instead of being satisfied with our generous slice. So we made all preparations and left Colony House early one morning.

To be equal to the occasion we went in full force, with two servants, an Indian and a black, and an automobile full of duffle, guns, nets to catch the young birds, glasses, notebooks, gamebags, and ropes. As usual it poured in torrents at daybreak but cleared somewhat as we started. A reckless Creole driver hurled our tiny Ford through deep puddles and around corners, and we rocked and skidded and splashed, and were forever just grazing coolies and their carts.

A land of a thousand surprises! We stopped a moment at the lunatic asylum to borrow an 
ax, and it was presently brought to us by a smiling, kindly old coolie inmate, who kept murmuring Hindustani to himself. As we drove on, a gigantic black man appeared on the ridgepole of the highest building and, stark naked, rushed aimlessly back and forth, stamping gleefully on the corrugated iron, and chanting as he stamped. We gazed on the axe and for once did not chide the driver in his reckless progress.

With relief we reached the bridge, where our Scotch friend had kindly provided mule, rope, boat, and coolies. We waited for a while, but as the downpour showed no signs of abating, we started on one of the wildest, weirdest journeys I have ever taken. The trench was narrow and deep, the boat was overladen, the banks were erratic, the mule was fractious, and the coolies were extremely unskilful. For the first half-mile the trench was crowded with great dreadnaughts of iron cane-boats, wholly irresponsible in position and movements. In places our speed caused a troubling of the water far ahead, and this now and again swung a cane-barge directly across our path. Again and again the stern of our boat would develop a sentient mind of its 
own and swirl ahead. Then followed a chorus of yells at the mule-boy, and a nervous halfrising in the boat, and a still more terrible silence, broken at last by a crash-hollow and echoing if we struck a cane-barge, splintering if against a $\log$ or stump. The boat would tip, several gallons of water pour in, and then there became audible our minute and detailed opinions of coolies and mules in general and ours in particular.

Of course every one who came between our mule and the bank had to flee, or else was scraped into the trench by the rope; and we left in our wake knots of discomfited coolie women who had been washing themselves or their clothes and who had to escape at the last moment. Calves were a source of intense excitement, and thcir gambols and intricate manipulations of our rope would have been highly amusing if the result of each encounter had not been mixed up so acutely with our own fate. I sat crouched down, a water-soaked mound of misery. Miserable, for I was still partly dry, having on the only raincoat, for the purpose of protecting our precious camera. Watcr ran up hill that morning, seeking out crcvices and buttonholes by 
which to penetrate to my person and to the leather-covered box which was so precious.

Things went better after we made the discovery that we were progressing bow-hindmost. And all the time the rain poured down, and coolie women and girls plodded drearily by to work. We landed finally and, in despair of photography, I cached the camera beneath a slanting tree. Then we began a tramp through all the mud in the world. There is only one - lace where the mud is deeper and more sticky than by a sugar-plantation trench, and that is on the dividing dikes of a Chinese rice-field. We slipped and slid, and when our shoes became too heavy to lift, we dabbled them in the trench and washed them. In brief intervals of less heavy rain we watched passing herons and hawks, while giant anis bubbled and grunted in surprise at our procession.

At last the never-to-be-forgotten hoarse gutturals of hoatzins came to our ears, and dimly through the rain we saw one small branchful of four birds, hunched up with drenched plumage. Two others were posed as rain-worshipersrufous wings widespread, heads stretched out, welcoming the sheets of water which poured 


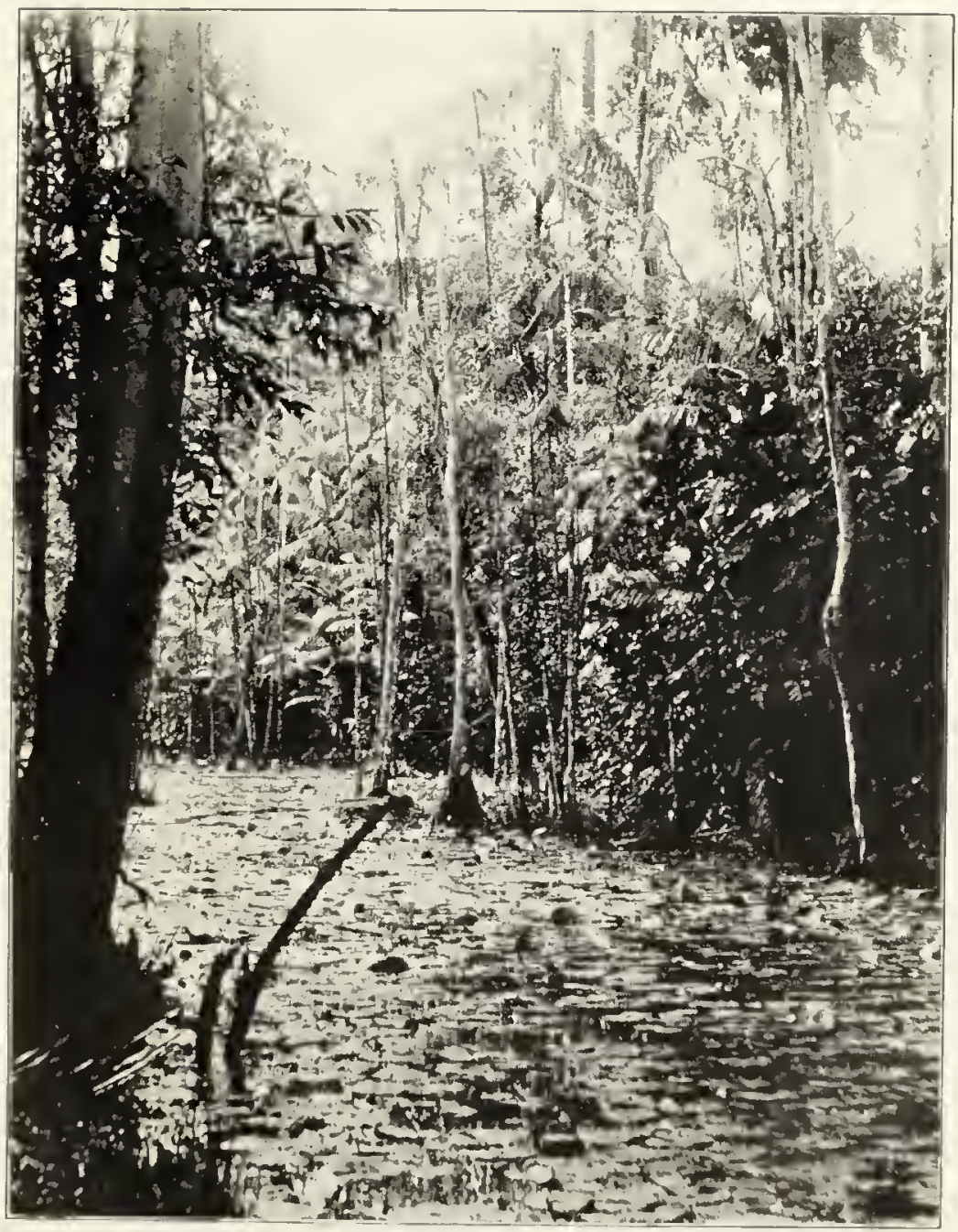

$$
\text { A lloatsin swamp }
$$





\section{A HUNT FOR HOATZINS}

over them. Their wild crests, though sodden and glued together, were still erect, dripping and swaying. We encircled the clump of trees and found deep canals and trenches on all sides. We shot one bird, which, true to its reptilian nature, spread both wings, locked its flight feathers among the twists of a liana tangle, and there hung suspended out of reach.

A strange coolie now appeared out of the mist and promised many, many, many anaquas "not too far" beyond. We shook the wet from our hat-brims, squeezed it from our shoes, and plodded on. The cane-fields seemed never-ending, always separated by lily-covered trenches. Then came half-swampy expanses with scattered trees. Careful search revealed another half-dozen hoatzins, sheltered among the dense foliage of the tallest tree. No nests were visible, and the rain was so heavy that we could not look upward. In the midst of the vague expanse of this dreary world a rootie spine-tail perched in a tree and sang three notes. We shot him because we could think of no other way at that moment of relieving our feelings. Then we had a reaction, almost hysterical, and the coolies murmured, "Padliadme" (madmen), and we 
laughed loudly again and again and started homeward. We chaffed the coolies until they were embarrassed; we slid into the deepest holes we could find. We made set speeches on the dampness of sugar-plantations, on tropical weather, and especially on the veracity of the indentured inhabitants of India. It was all as good-natured as it sounded, for, after all, had we not already found the birds themselves and obtained our notes and photographs?

Then we discussed the psychology of rain and of getting wet, and I arrived at the following conclusions, which are true ones. Once drenched to the skin in the tropics, all discomfort is gone. One simply squdges around in the blissful knowledge that all the mud and water in the world can now arouse no feeling of discomfort. One has simply been translated to a new world of elements, a new cosmos of sensation. And as with most such transmigrations, it is only the shifting which is disagreeable. As long as a shred of clothing is dry, we think of it and worry about it, and endeavor to keep it dry, and shrink from the clammy touch of partly sodden foot-wear. Once we slip into a trench, the rain becomes only a pleasant tapping on 
one's shoulders, a rhythmical, liquid vibration. With all fear eliminated, water and mud become no more unpleasant than air and earth. So our plantation expedition, like Gaul, may be divided into three parts: first, a thrilling, dangerous, expectant phase; a brief second period of thoroughly disappointing revelation; third, a jolly, unscientific, and wholly hilarious finale. These are the trips which no explorer or traveler mentions, because there are no tangible returns. But it is seldom that any expedition, however barren of direct results, cannot be made to yield some viewpoint of interest.

The sun had just risen when the little ferryboat left the stelling on its way to the railway station on the opposite bank of the river. Half of the jungle across the Berbice was dark, dark green, almost black, with a fragment of rainbow hung obliquely above it, tangled in blueblack clouds. A little way up-river the level sun's rays struck fairly, and the rounded, cloudlike billows of foliage were of palest sage-green. Our shore was all one blatant glare, flooded already with the violent light of a tropical day. Against the black Berbice cloud a hundred 
fork-tailed flycatchers flashed and vanished alternately as they swerved and careened. Steadily across its threatening face was drawn a single line of scarlet-a score of ibises glowing like the essence of rubies. 


\section{HOATZINS AT HOME}

THE flight of the hoatzin resembles that of an over-fed hen. The hoatrin's voice is no more melodious than the cry of a peacock, and less sonorous than an alligator's roar. The bird's grace is batrachian rather than avian, while the odor of its body resembles that of no bird untouched by dissolution. Still, zoölogically considered, the hoatzin is probably the most remarkable and interesting bird living on the earth today.

It has suecessfully defied time and space. For it, the dial of the ages has moved more slowly than for the rest of organie life, and although living and breathing with us today, yet its world is an affair of two dimensions-a line of thorny saplings threaded along the muddy banks of a few tropieal waters.

$A$ bird in a eage cannot escape, and may be found month after month wherever the eage is 
placed. A stuffed bird in a case may resist disintegration for a century. But when we go to look for the bluebirds which nest in the orchard, they may have flown a half mile away in their search for food. The plover which scurries before us today on the beach may tonight be far away on the first lap of his seven thousand mile flight to the southward.

The hoatzin's status lies rather with the caged bird. In November in New York City an Englishman from British Guiana said to me, "Go to the Berbice River, and at the north end of the town of New Amsterdam, in front of $\mathrm{Mr}$. Beckett's house, you will find hoatzins." Six months later as I drove along a tropical river road I saw three hoatzins perched on a low thorn bush at the river's edge in front of a house. And the river was the Berbice, and the house that of Mr. Beckett.

Thus are the hoatzins independent of space, as all other flying birds know it, and in their classic reptilian affinities,--voice, actions, arms, fingers, habits,- they bring close the dim epochs of past time, and renew for our inspection the youth of bird-life on the earth. It is discouraging ever to attempt to translate habits fraught 
with so profound a significance into words, or to make them realistic even with the aid of photographs.

We took a boat opposite Mr. Beckett's house, and paddled slowly with the nearly-flood tide up the Berbice River. It was two o'clock, the hottest time of the day. For three miles we drifted past the chosen haunts of the hoatzins. All were perched in the shade, quiet in the intense heat, squatting prostrate or sleepily preening their plumage. Now and then we saw a bird on her nest, always over the water. If she was sitting on eggs she sat close. If young birds were in the nest she half-crouched, or perched on the rim, so that her body cast a shadow over the young.

The vegetation was not varied. Muckamucka was here and there in the foreground, with an almost solid line of bunduri pimpler or thorn tree. This was the real home of the birds, and this plant forms the background whenever the hoatzin comes to mind. It is a growth which loves the water, and crowds down so that the rising of the tide, whether fresh or brackish, covers the mud in which it stands, so that it appears to be quite as aquatic as the man- 
grove which, here and there, creeps out alongside it.

The pimpler bears thorns of the first magnitude, often double, recurved and at such diabolically unexpected places, that like barbed wire, it is impossible to grasp anywhere without drawing blood. Such a chevaux-de-frise would defend a trench against the most courageous regiment. The stems were light gray, greening toward the younger shoots, and the foliage was pleasantly divided into double lines of locust-like leaflets.

The plants were in full flower,-dainty, upright panicles of wisteria-like pea-blooms, pale violet and white with tiny buds of magenta. A faint, subdued perfume drifted from them through the tangle of branches. The fruit was ripening on many plants, in clusters of green, semi-circular, flat, kidney pods. The low branches stretched gracefully waterwards in long sweeping curves. On these at a fork or at the crossing of two distinct branches, the hoatzins placed their nests, and with the softtissued leaflets they packed their capacious crops and fed their young.

Besides these two plants, which alone may 
be considered as forming the principal environment, two blooms were conspicuous at this season; a deep-calyxed, round blossom of rich yellow,-an hibiscus, which the Indians called makoe, and from the bark of which they made most excellent rope. The other flower was a vine which crept commonly up over the pimpler trees, regardless of water and thorns, and hung out twin blossoms in profusion, pink and pinkishwhite, trumpet-shaped, with flaring lips.

The mid-day life about this haunt of hoatzins was full of interest. Tody-flycatchers of two species, yellow-breasted and streaked, were the commonest birds, and their little homes, like bits of tide-hung drift, swayed from the tips of the pimpler branches. They dashed to and fro regardless of the heat, and whenever we stopped they came within a foot or two, curiously watching our every motion. Kiskadees hopped along the water's edge in the shade, snatching insects and occasionally splashing into the water after small fish. Awkward Guinea green herons, not long out of the nest, crept like shadow silhouettes of birds close to the dark water. High overhead, like flecks of jet against the blue sky, the vultures soared. Green dragonflies whirled 
here and there, and great blue-black bees fumbled in and out of the hibiscus, yellowed with pollen and too busy to stop a second in their day-long labor.

This little area held very strange creatures as well, some of which we saw even in our few hour's' search. Four-eyed fish skittered over the water, pale as the ghosts of fish, and when quiet, showing only as a pair of bubbly eyes. Still more weird hairy caterpillars wriggled their way through the muddy, brackish current -aquatic larvae of a small moth which I had not seen since $I$ found them in the trenches of Pará.

The only sound at this time of day was a drowsy but penetrating tr-r-r-r-r-p! made by a green-bodied, green-legged grasshopper of good size, whose joy in life seemed to be to lie lengthwise upon a pimpler branch, and skreek violently at frequent intervals, giving his wings a frantic flutter at each utterance, and slowly encircling the stem.

In such environment the hoatzin lives and thrives, and, thanks to its strong body odor, has existed from time immemorial in the face of terrific handicaps. The odor is a strong musky 
one, not particularly disagreeable. I searched my memory at every whiff for something of which it vividly reminded me, and at last the recollection came to me-the smell, delectable and fearfully exciting in former years-of elephants at a circus, and not altogether elephants either, but a compound of one-sixth sawdust, another part peanuts, another of strange animals and three-sixths swaying elephant. That, to my mind, exactly describes the odor of hoatzins as I sensed it among these alien surroundings.

As I have mentioned, the nest of the hoatzin was invariably built over the water, and we shall later discover the reason for this. The nests were sometimes only four feet above high water, or equally rarely, at a height of forty to fifty feet. From six to fifteen feet included the zone of four-fifths of the nests of these birds. They varied much in solidity, some being frail and loosely put together, the dry, dead sticks which composed them dropping apart almost at a touch. Usually they were as well knitted as a heron's, and in about half the cases consisted of a recent nest built upon the foundations of an old one. There was hardly any cavity at the 
top, and the coarse network of sticks looked like a precarious resting place for eggs and an exceedingly uncomfortable one for young birds.

When we approached a nest, the occupant paid no attention until we actually came close to a branch, or shook it. She then rose, protesting hoarsely, and lifting wings and tail as she croaked. At the last moment, often when only a yard away, she flew off and away to a distance of fifty feet or more. Watching closely, when she realized that we really had intentions on her nest, she returned and perched fifteen or twenty feet away, croaking continually, her mate a little farther off, and all the hoatzins within sight or hearing joining in sympathetic disharmony, all with synchronous lifting of tail and wings at each utterance.

The voice of the female is appreciably deeper than that of the male, having more of a gurgling character, like one of the notes of a curassow. The usual note of both sexes is an unwritable, hoarse, creaking sound, quite cicada or frog-like.

Their tameness was astounding, and they would often sit unmoved, while we were walking noisily about, or focusing the camera within two 
yards. If several were sitting on a branch and one was shot, the others would often show no symptoms of concern or alarm, either at the noise of the gun or the fall of their companion. A hoatzin which may have been crouched close to the slain bird would continue to preen its plumage without a glance downward. When the young had attained their first full plumage it was almost impossible to distinguish them from the older members of the flock except by their generally smaller size.

But the heart of our interest in the hoatzins centered in the nestlings. Some kind Providence directed the time of our visit, which I chose against the advice of some of the very inhabitants of New Amsterdam. It turned out that we were on the scene exactly at the right time. A week either way would have yielded much poorer results. The nestlings, in seven occupied nests, observed as we drifted along shore, or landed and climbed among the thorns, were in an almost identical stage of development. In fact, the greatest difference in size occurred between two nestlings of the same brood. Their down was a thin, scanty, fuzzy covering, and the flight feathers were less than 
a half-inch in length. No age would have showed to better advantage every movement of wings or head.

When a mother hoatzin took reluctant flight from her nest, the young bird at once stood upright and looked curiously in every direction. No slacker he, crouching flat or awaiting his mother's directing cries. From the moment he was left alone he began to depend upon the warnings and signs which his great beady eyes and skinny ears conveyed to him. Hawks and vultures had swept low over his nest and mother unheeded. Coolies in their boats had paddled underneath with no more than a glance upward. Throughout his week of life, as through his parents' and their parents' parents' lives, no danger had disturbed their peaceful existence. Only for a sudden windstorm such as that which the week before had upset nests and blown out eggs, it might be said that for the little hoatzin chicks life held nothing but siestas and munchings of pimpler leaves.

But one little hoatzin, if he had any thoughts such as these, failed to count on the invariable exceptions to every rule, for this day the totally unexpected happened. Fate, in the shape of 
enthusiastic scientists, descended upon him. He was not for a second nonplussed. If we had concentrated upon him a thousand strong, by boats and by land, he would have fought the good fight for freedom and life as calmly as he waged it against us. And we found him no mean antagonist, and far from reptilian in his ability to meet new and unforeseen conditions.

- His mother, who a moment before had been packing his capacious little crop with predigested pimpler leaves, had now flown off to an adjoining group of mangroves, where she and his father croaked to him hoarse encouragement. His flight feathers hardly reached beyond his finger-tips, and his body was covered with a sparse coating of sooty black down. So there could be no resort to flight. He must defend himself, bound to earth like his assailants.

Hardly had his mother left when his comical head, with thick, blunt beak and large intelligent eyes, appeared over the rim of the nest. His alert expression was increased by the suspicion of a crest on his crown where the down was slightly longer. Higher and higher rose his head, supported on a neck of extraordinary length and thinness. No more than this was 
needed to mark his absurd resemblance to some strange, extinct reptile. A young dinosaur must have looked much like this, while for all that my glance revealed, I might have been looking at a diminutive Galapagos tortoise. Indeed this simile came to mind often when I became more intimate with nestling hoatzins.

Sam, my black tree-climber, kicked off his shoes and began creeping along the horizontal limbs of the pimplers. At every step he felt carefully with a calloused sole in order to avoid the longer of the cruel thorns, and punctuated every yard with some gasp of pain or muttered personal prayer, "Pleas' doan' stick me, Thorns!"

At last his hand touched the branch, and it shook slightly. The young bird stretched his mittened hands high above his head and waved them a moment. With similar intent a boxer or wrestler flexes his muscles and bends his body. One or two uncertain, forward steps brought the bird to the edge of the nest at the base of a small branch. There he stood, and raising one wing leaned heavily against the stem, bracing himself. My man climbed higher and the nest swayed violently. 


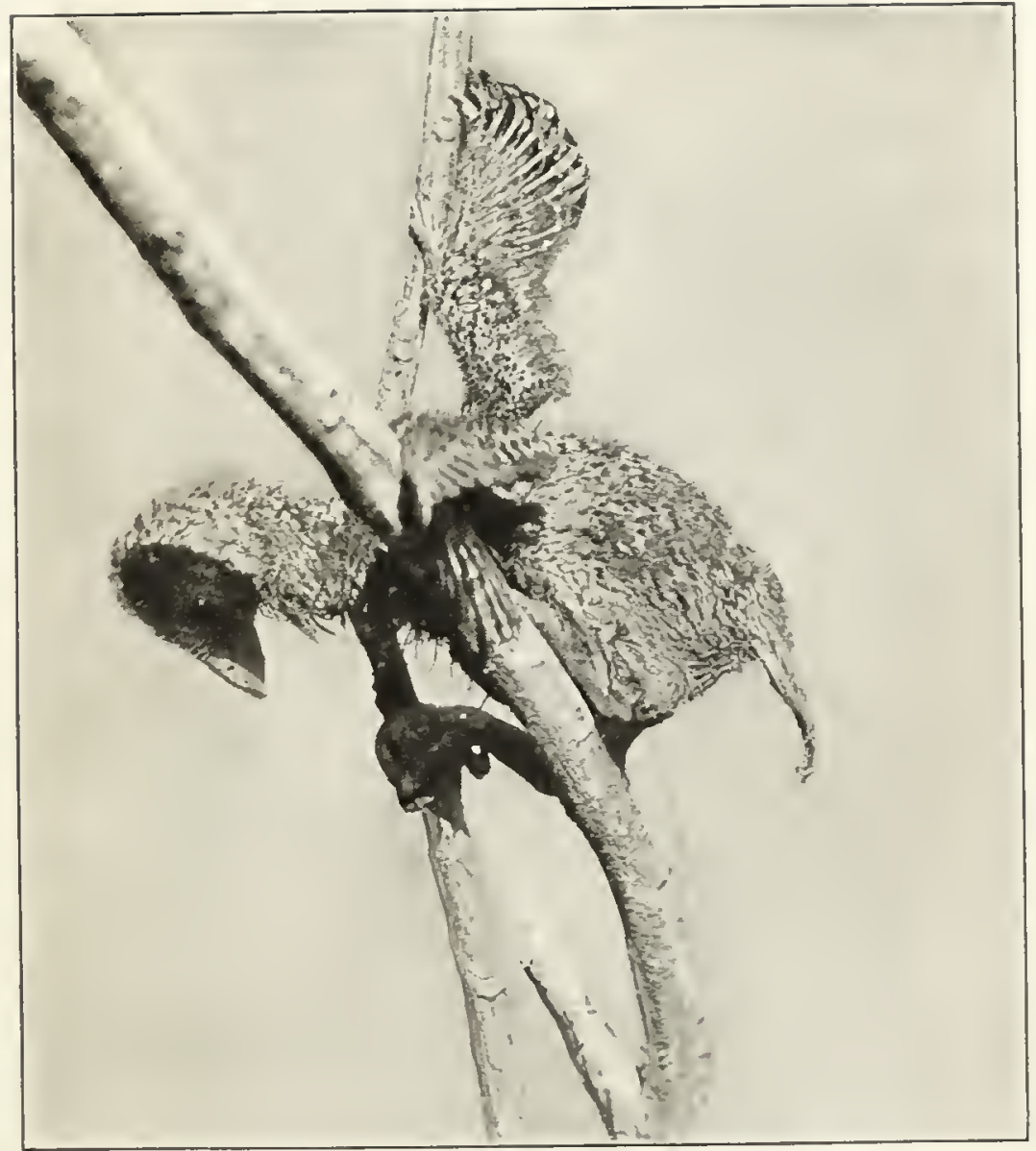

Vestling IIoatzin Climbing with Thumb and Forefinger 

Now the brave little hoatzin reached up to some tiny side twigs and aided by the projecting ends of dead sticks from the nest, he climbed with facility, his thumbs and forefingers apparently being of more aid than his feet. It was fascinating to see him ascend, stopping now and then to crane his head and neck far out, turtlewise. He met every difficulty with some new contortion of body or limbs, often with so quick or so subtle a shifting as to escape my scrutiny. The branch ended in a tiny crotch and here perforce, ended his attempt at escape by climbing. He stood on the swaying twig, one wing clutched tight, and braced himself with both feet.

Nearer and nearer crept Sam. Not a quiver on the part of the little hoatzin. We did not know it, but inside that ridiculous head there was definite decision as to a deadline. $\mathrm{He}$ watched the approach of this great, strange creature-this Danger, this thing so wholly new and foreign to his experience, and doubtless to all the generations of his forbears. A black hand grasped the thorny branch six feet from his perch, and like a flash he played his next trick-the only remaining one he knew, one that 
set him apart from all modern land birds, as the frog is set apart from the swallow.

The young hoatzin stood erect for an instant, and then both wings of the little bird were stretched straight back, not folded, bird-wise, but dangling loosely and reaching well beyond the body. For a considerable fraction of time he leaned forward. Then without effort, without apparent leap or jump he dived straight downward, as beautifully as a seal, direct as a plummet and very swiftly. There was a scarcely-noticeable splash, and as I gazed with real awe, I watched the widening ripples which undulated over the muddy water-the only trace of the whereabouts of the young bird.

It seemed as if no one, whether ornithologist, evolutionist, poet or philosopher could fail to be profoundly impressed at the sight we had seen. Here I was in a very real, a very modern boat, with the honk of motor horns sounding from the river road a few yards away through the bushes, in the shade of this tropical vegetation in the year nineteen hundred and sixteen; and yet the curtain of the past had been lifted and I had been permitted a glimpse of what must have been common in the millions of years ago. It 
was a tremendous thing, a wonderful thing to have seen, and it seemed to dwarf all the strange sights which had come to me in all other parts of the earth's wilderness. I had read of these habits and had expected them, but like one's first sight of a volcano in eruption, no reading or description prepares one for the actual phenomenon.

I sat silently watching for the re-appearance of the young bird. We tallied five pairs of eyes and yet many minutes passed before I saw the same little head and emaciated neck sticking out of the water alongside a bit of drift rubbish. The only visible thing was the protruding spikes of the bedraggled tail feathers. I worked the boat in toward the bird, half-heartedly, for I had made up my mind that this particular brave little bit of atavism deserved his freedom, so splendidly had he fought for it among the pimplers. Soon he ducked forward, dived out of sight and came up twenty feet away among an inextricable tangle of vines. I sent a little cheer of well wishing after him and we salvaged Sam.

Then we shoved out the boat and watched from a distance. Five or six minutes passed 
and a skinny, crooked, two-fingered mitten of an arm reared upward out of the muddy flood and the nestling, black and glistening, hauled itself out of water.

Thus must the first amphibian have climbed into the thin air. But the young hoatzin neither gasped nor shivered, and seemed as self-possessed as if this was a common occurrence in its life. There was not the slightest doubt however, that this was its first introduction to water. Yet it had dived from a height of fifteen feet, about fifty times its own length, as cleanly as a seal leaps from a berg. It was as if a human child should dive two hundred feet!

In fifteen minutes more it had climbed high above the water, and with unerring accuracy directly toward its natal bundle of sticks overhead. The mother now came close, and with hoarse rasping notes and frantic heaves of tail and wings lent encouragement. Just before we paddled from sight, when the little fellow had reached his last rung, he partly opened his beak and gave a little falsetto cry,-a clear, high tone, tailing off into a guttural rasp. His splendid courage had broken at last; he had nearly reached the nest and he was aching to put aside 
all this terrible responsibility, this pitting of his tiny might against such fearful odds. He wanted to be a helpless nestling again, to crouch on the springy bed of twigs with a feather comforter over him and be stuffed at will with delectable pimpler pap. Such is the normal right destiny of a hoatzin chick, and the rohee-og! wrung from him by the reaction of safety seemed to voice all this. 


\section{VII}

\section{A WILDERNESS LABORATORY}

Robinson Crusoe had a wreck well stored with supplies, and we inherited only four walls and a roof. Still, we had a boy Friday-Sam, an ebony Demeraran, exactly half of whose teeth had been lost in the only automobile ride he had ever taken. Sam was sent by some personal Providence-perhaps the god of intelligence bureaus-as the first of our faithful following in Guiana. Sam had formerly been a warden in the Georgetown jail, and rumor had it that he left because he saw "jumbies" in the court where one hundred and nine men had been hung. And surely that was where jumbies would be found if anywhere. Even Crusoe's man must have admitted that. How wardenship could be of aid to us in our scientific work was a puzzle.

Only once before did a servant's previous experience surpass this in utter uselessness. 
That was when a Russian chauffeur whom I had taken on trial found a cowboy saddle in my attic and seriously and proudly showed me in great detail, with the saddle strapped to the banisters, how with his long Cossack training he could stand on his neck when going at full speed! But Sam, like many another servant of the past, was to prove a treasure.

We had come from New York with a very distinct idea of what we wanted to do, but no idea at all of just how or where we should begin. On kindly but conflicting advice and suggestion, we had searched hither and thither over the coastlands of British Guiana. Everywhere we found drawbacks. We wanted to be near primeval jungle, we wished to be free of mosquitoes and other disturbers of longcontinued observation. We desired the seemingly impossible combination of isolation and facility of communication with the outside world.

In a driving, tropical rainstorm I ascended the Essequibo to Bartica, and from the hills, as the sun broke through gray clouds, my friend the rubber planter pointed over two jungle-clad ranges to a great house, a house with many pillars, a house with roof of pale pink like a giant 
mora in full bloom. Then, like the good fairy prince in a well-regulated tale, he waved his wand toward it, and said, "That is Kalacoon; take it and use it if you want it." Only his wand was a stout walking-stick, and for the nonce the fairy prince had taken the form of a tall, bronzed, very good-looking Englishman, who had carved a rubber plantation out of the very edge of the jungle, and with wife and small daughter lived in the midst of his cleanbarked trees.

And now we had had a gift of a great house in the heart of the Guiana wilderness, a house built many years before by one who was Protector of the Indians. This we were to turn into a home and a laboratory to study the wild things about us-birds, animals, and insects; not to collect them primarily, but to photograph, sketch, and watch them day after day, learning of those characters and habits which cannot be transported to a museum. And exactly this had not been done before; hence it took on new fascination.

I had never given serious thought to the details of housekeeping, and I suddenly realized how much for granted one takes things in civi- 
lization. In New York I had possessed beds and baths and tables, dishes and cooks and towels, in a spirit of subconsciousness which made one think of them only if they were not there. Now I had suddenly to think about all these and other things particularly hard. If it had been the usual camping duffle of hammock, net, tarpaulin, and frying-pan, that would have been simple. But when the sugar-bowl is empty, one becomes at once acutely conscious of it; if it is not, while the hand unbidden manipulates the tongs, the brain distils or listens to thoughts of opera, science, or war. Optical eclipse, impelled by familiarity, is often total. However, we found the Georgetown stores well stocked, and whenever we purchased a useless thing we found that it could be used for something else. And sooner or later, everything we possessed was used for something else, thereby moving one of us to suggest a society for reducing household articles by half.

But while it was well enough to make a lark of such things when one had to, we begrudged every minute taken from the new field outspread before us in every direction. For Kalacoon was on a hilltop and looked out on the northern third 
of the horizon over the expanse of three mighty rivers-the Essequibo, the Mazaruni, and the Cuyuni. And around us was high second growth, losing itself to the southward in a gigantic, abrupt wall of the real jungle-the jungle that I knew by experience was more wonderful than any of the forests of the Far East, of Burma or Ceylon or Malaysia.

We sat down on some packing-boxes after our first day of indoor labor, and watched the sun settle slowly beyond the silvered Mazaruni. And a song, not of the tropics, but bubbling and clear and jubilant as that of our northern singers, rang out from the single tall palm standing in our front compound. Clinging to the topmost frond was an oriole, jet as night, with the gold of sunshine on crown and shoulders and back. He was singing. While he sang, a second oriole swooped upward between two vanes of a frond to a small ball of fibers knotted close to the midrib. The event had come and it developed swiftly.

We seized a great ladder and by superhuman efforts raised it little by little, until it rested high against the smooth trunk. One of us then mounted the'swaying rungs, reckless with ex- 
citement, and thrust his hand into the nest. It was withdrawn and went to his mouth, and down he came. To our impatient, impolite inquiries, he answered only with inarticulate mumblings and grunts. He reached the ground and into his pursed hands carefully regurgitated an egg-white, with clustered markings of lavender and sepia about the larger end. We looked at each other and grinned. Words seemed superfluous. Later I believe we quieted down and danced some kind of a war-dance. Our feelings had then reached the stage where they could at least be expressed in action. Perhaps it was not altogether the scientific joy of gazing at and possessing the first known egg of the moriche oriole. I know that by sheer perversity I kept thinking of the narrow-gauge canyon of a city street, as I gloried in this cosmic openness of tropical river and jungle and sunset. Only in an aeroplane have I experienced an equal spatial elation.

Our bird-nester told us that there was a second egg, and said something about not daring to put two in his mouth lest he slip and swallow both. But later, in a moment of weakness, he admitted the real reason,- - that he had not the 
heart, after the glorious song and this splendid omen of our work, to do more than divide the spoils fifty-fifty with the orioles. Self-control was rewarded, as the other egg hatched and we learned a secret of the juvenile plumage of these birds, while the songs of the cadouries, as the Indians call them, were heard month after month at our windows.

When the idea of a tropical research station occurred to me, the first person with whom I discussed the matter was Colonel Roosevelt. In all of my scientific undertakings under the auspices of the New York Zoölogical Society, I have found his attitude always one of wholesouled sympathy, checked and practicalized by trenchant criticism and advice. For Colonel Roosevelt, besides his other abilities and interests, is one of the best of our American naturalists. To a solid foundation of scientific knowledge, gained direct from literature, he adds one of the widest and keenest of experiences in the field. His published work is always based on a utilization of the two sources, and is characterized by a commendable restraint and the leaven of a philosophy which combines an unalterable adhesion to facts, with moderation of theory 


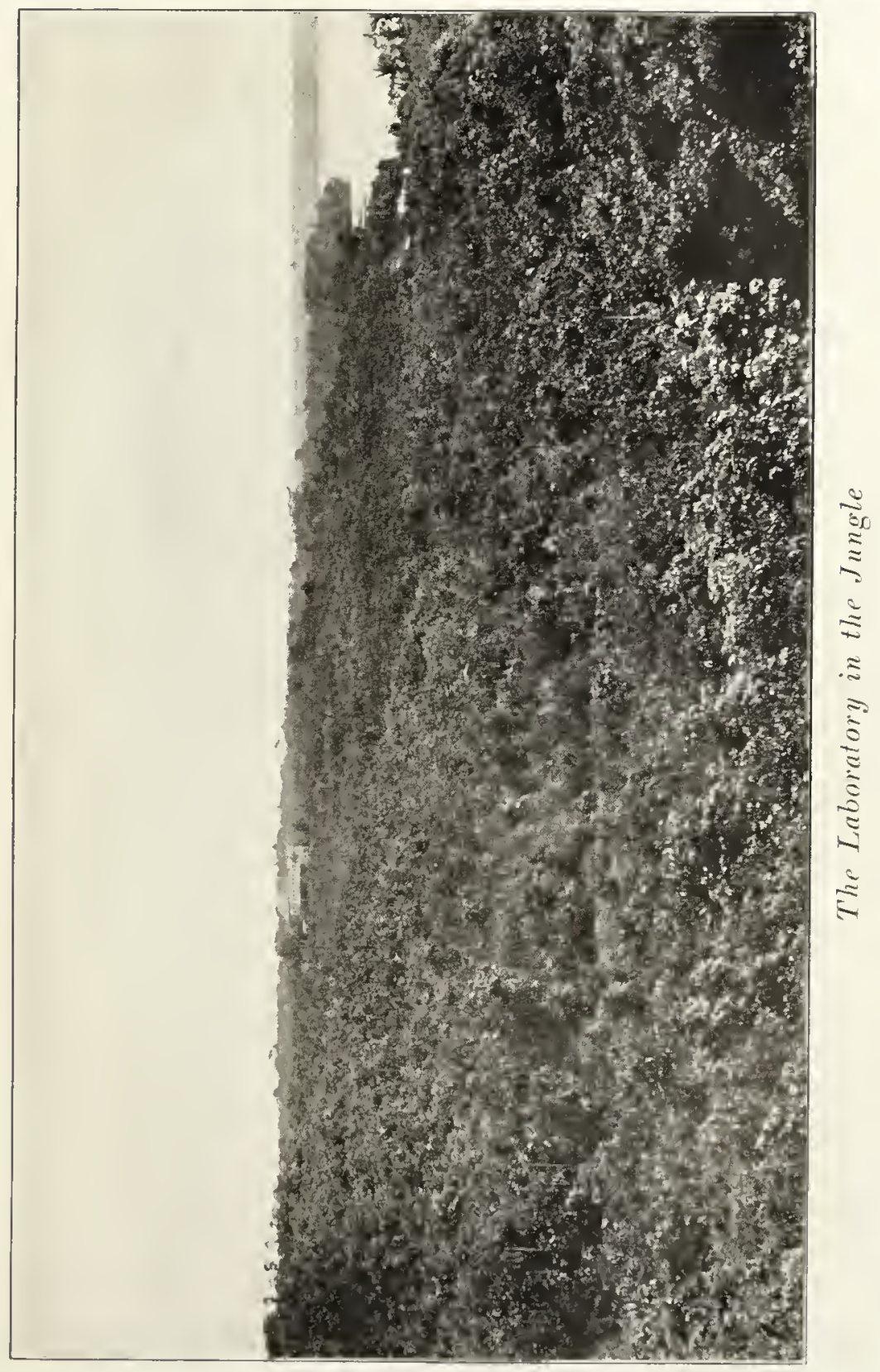



and an unhesitating use of the three words which should be ready for instant use in the vocabulary of every honest scientist, "I don't know."

My object in founding the research station was to destroy the bogie of danger and difficulty supposed to attend all tropical investigation, and to show that scientists from north temperate regions could accomplish keen, intensive, protracted scientific work in tropical jungles without injury to health or detriment to the facility of mental activity, and at extremely moderate expense. This will open to direct personal investigation, regions which, more than any others, promise dynamic results from evolutional study, and will supplement the work of museums with correlated researches upon living and freshly killed organisms. This was a "progressive" doctrine which Colonel Roosevelt endorsed with enthusiasm, and after we had brought semblance of a comfortable American home to great, rambling Kalacoon, we were able to welcome Colonel and Mrs. Roosevelt as the first visitors to the actual accomplishment of the project which months before, we had so enthusiastically discussed at Oyster Bay. 
The jungles of South America were no novelty to Colonel Roosevelt, but to be able to traverse them over smooth, easy trails, in a comfortable temperature and with no annoyance of flies or mosquitoes, was an experience which none of us had enjoyed before. To Mrs. Roosevelt it was all new-the huge, buttressed trunks, the maze of lianas in tangles, loops and spirals, the sudden burst of pink or lavender blossoms in a sunlit spot, and the piercingly sweet, liquid notes of the goldbird, "like the bird of Siegfried," as she aptly said. The coolie workmen in their Eastern garb, the Akawai Indian hunters and their tattooed squaws along the trail, all aroused that enthusiasm which a second meeting can never quite elicit.

Most memorable to me were the long walks which Colonel Roosevelt and I took on the Kaburi Trail, that narrow path which is the only entrance by land to all the great hinterland lying between the Essequibo and Mazaruni Rivers. Majestically the massive trees rose on either side, so that while our contracted aisle was as lofty as the nave of a cathedral, yet it was densely shaded by the interlocking foliage 
high overhead. Our progress was thus through a glorified tunnel; we traveled molewise with only here and there a glimpse of the sky. Every walk was filled to the brim for me with that infinitely satisfying joy, derived from frank, sympathetic communion with an enthusiastic, true friend. I know of no earthly pleasure more to be desired. Perhaps this is because friends are so rare with whom one can be wholly natural, with one's guard completely down, unafraid of any misunderstanding-an omnimental communion.

It was with dismay, at the end of one long walk, that I realized we had forgotten to search for the tropical creatures for which we had presumably set out. We had kept the jungle birds and animals well at distance by a constant flow of human speech-argumentative, eulogistic, condemnatory-of literary and field and museum doings of the scientific world.

But we did not wholly neglect the life around us and one of the last problems which we solved that day was that of a small voice, one of those apparently unattached sounds which come from no definite place, nor are referable to any certain source. It might have been a cicada or 
other insect, it could well have come from the throat of a bird. Were we in the heart of a city we should unhesitatingly have pronounced it a jewsharp played very badly. We set out in search, we stalked it through the thin underbrush, we scanned every branch with our glasses, and when we found it was bird and not insect we shamelessly played upon its feelings and squeaked after the manner of a stricken nestling. We saw that it was a small flycatcher, green with waistcoat of lemon-yellow. Finally after we had learned its fashion of flight, the stratum of jungle it inhabited and its notes, I" secured it. Not until then did we perceive that concealed on its head it wore a glorious crown of orange and gold. When my reference books arrive, and we learn the technical name of this little golden-crowned flycatcher or cotinga, I do not think that this title will persist as vividly as the " jewsharp bird of Kaburi trail."

Close to where we walked on those first days, we were later to find our best hunting. During the next few months all the more interesting animals of this part of South America were shot or their presence noticed; jaguars, tapirs, deer, 
peccaries, howling monkeys, vampires, agoutis, jaguarondis, otters, sloths, and armadillos. Hosts of birds, almost half the entire number of species found in the Colony, made their home hereabouts, macaws, bellbirds, curassows, trumpeters, toucans, the great harpy eagle and the tiniest of iridescent hummingbirds.

Within a week our great front room, full thirty by sixty feet, with sixteen large windows, was a laboratory in appearance and odor. Hundreds of jars and vials, vivaria and insectaries, microscopes, guns, and cameras, with all their details and mysterious inner workings, left no table vacant. With book-shelves up, there remained only the walls, which little by little became mosaics of maps, diagrams, sketches, drying skins, Indian weapons, birds' nests and shot-holes. Whiffs of formaline, chloroform, and xylol, together with the odors of occasional mislaid or neglected specimens, left no doubt as to the character of the room. We found that the tradewind came from the front, and also that we had much to discuss after the lamps were put out; so we turned the couches into their rightful functions of cots, and the three of 
us slept scattered here and there in the great room.

The vampire bats never allowed us to become bored. There were no mosquitoes or flies, so we used no nets; but for months we burned a lantern. Low around our heads swept the soft wings of the little creatures, while the bat enthusiast now and then fired his auxiliary pistol. Later we found that a score of them roosted behind a broken clapboard, and, by spreading a seine below and around this, we were able to capture and examine the entire colony at will. Tarantulas were common, but not in the least offensive, and we learned to know where to look for a big black fellow and a small gray one who kept the room free from cockroaches. One or two scorpions were caught indoors, but the three centipedes which appeared occasionally were those which had been brought in and were always escaping from a defective vivarium. There were no other dangers or inconveniences, if we can apply such terms to these comparatively harmless creatures.

This was the background of our labors, our laboratory as our English visitors called it: cool in the daytime, cold at night, where one 
could work as well as in the north, and where a morning's tramp usually furnished material sufficient for a week of research. We came to know it as the house of a thousand noises. The partitions, like those of all tropical houses, extended only part way to the ceiling, so, as some one has said, one enjoyed about the privacy of a goldfish. It would have been a terrible place for a victim of insomnia; but when we were kept awake by noises it was because we were interested in them. After a day's hard work in the jungle, it must indeed be a bad conscience or a serious physical ailment which keeps one awake a minute after one rolls up in his blanket. Through all the months of varying tropical seasons we slept as soundly as we should at home. I can do with five or six hours' sleep the year round, and I begrudged even this in the tropical wonderland, where my utmost efforts seemed to result in such slight inroads into our tremendous zoölogical ignorance. At night I spent many wonderful hours, leaning first out of one, then out of another window, or occasionally going down the outside lattice stairway and strolling about the compound.

No two nights were alike, although almost 
all were peaceful, with hardly a breath of air stirring-just the cool, velvet touch of the tropics, always free from any trace of the heat of the day. Whether dark rich olive under crescent or starlight, or glowing silvery-gray in the flood of the full moon, the forest, so quiet, so motionless all about me, was always mysterious, always alluring. To the north, at the foot of the hill, lay the dark surface of the great river, its waters one amber, homogeneous flood, yet drawn from a thousand tributaries: hidden creeks seeping through mossy jungles far beyond the Spanish border, brown cascades filtering through gravel which gleamed with yellow gold and sparkled with the light from uncut diamonds. And to the south rose the wall of the jungle itself, symbol of all that is wild and untamed in nature.

Yet I am never conscious of the bloody fang, the poison tooth, of the wilderness. The peace of this jungle at night was the same peace as that of the trees in our city parks. I knew that well within my horizon, jaguars and pumas were stalking their prey, while here and there on the forest floor bushmasters lay coiled like mats of death. But quite as vividly could I picture 
the stray cats pouncing on sleeping sparrows in the shrubbery of Washington Square, or the screech owls working havoc in the glades of Central Park where the glare of the electric lights is less violent. And I have not forgotten the two-score gulls and swans with torn throats - a single night's work of wild mink in the Bronx. Nature is the same everywhere; only here the sparrows are not alien immigrants, and the light is not measured in kilowatts, and the hacka tigers are not so sated that they kill for pleasure.

A sound broke in upon my reverie, so low at first that it seemed but the droning hum of a beetle's wing echoing against the hollow shield of their ebony cases. It was deep, soothing, almost hypnotic; one did not want it to cease. Then it gained in volume and depth, and from the heart of the bass there arose a terrible, subdued shrilling-a muffled, raucous grating which touched some secret chord of long-past fear. The whole effect was most terrifying, but still one did not desire it to cease. In itself it seemed wholly suited to its present jungle setting; the emotion it aroused was alien to all modern life. My mind sped swiftly back over the intervening 
years of sound, over the jeering chorus of Malay gibbons, the roars of anger of orangutans, four-handing themselves through the swaying Bornean jungle, and on past the impudent chatter of the gray langurs of Kashmir deodars. Memory came to rest in a tent-boat, seven years ago and not many more miles distant, when I heard my first red howlers. Then I shared my thrill. Now all with me were asleep, and alone I reached far out into the night and with mouth and ears absorbed every vibration of the wonderful chorus.

In spite of all this variety and immeasurable diversity, I came to perceive a definite sequence of many daily and nightly events, as I observed them from Kalacoon windows. Not only did the sun rise invariably in the east and the tradewinds blow regularly every afternoon, but a multitude of organic beings timed their activities to these elemental phenomena. At half after five, when it was just light enough to see distinctly, I went out into the calm dawn. The quiet of the great spaces at this hour was absolute. No matter how tempestuous the evening before or the night, the hours of early morning were peaceful. Not a leaf stirred. 
The tide flowed silently up or down or for a time held itself motionless. At the flood the mirror surface would occasionally be shattered for a moment far from shore, where a porpoise or a great lucannani rolled, or a crocodile or a water mama nosed for breath. The calm was invariable, but the air might be crystal clear to the horizon, or so drenched in mist that the nearest foliage was invisible.

No matter how early I went out into the dawn, the wrens were always singing-though they were recent arrivals at Kalacoon. Then, within a few minutes, the chachalacas began their loud duets, answering one another in couples from first one, then another direction, until the air was ringing with hanaqua! hanaqua! hanaqua! Dragonflies appeared in mid-air, martins left their nests among the beams, parrakeets crossed over from their roosts, and swifts met them coming from their sleeping quarters in hollow trees. The quaint little grassquits began their absurd dance against gravity, and blatant kiskadees ushered in the sun and day.

Then came an interval when every one was too busy feeding to sing, and the wren's notes were hushed by an astounding succession of 
tiny spiders, and the chirps of young martins were smothered in winged ants. Swiftly the sun rose and the heat dissipated the mists and lured out a host of flying things. Even at midday one might sit at a window and take notes continuously of lesser happenings, while now and then something of such note occurred that one could only watch and wonder. This might be a migration of sulphur butterflies, thousands flying steadily toward the southeast hour after hour, day after day. Or a host of hummingbirds of nearly a score of species would descend upon the cashew blossoms in the rear compound. Most exciting was a flight of winged termites. In the rainy season the clouds would bank up about mid-day, and showers fall with true tropical violence. After an exceptionally long downpour the marriage flight would take place and logs, dead branches, and even the steps and beams of Kalacoon would give up their multitudes. From great rotted stumps the insects poured forth like curling smoke. The breeze carried them slowly off toward the west, and at the first hint the birds gathered to the feast. Only Rangoon vultures surpassed them in numbers and voracity. The air was fretted with 
a kaleidoscopic network of swifts-from great, collared fellows to the tiny dwellers in palmswith swallows, martins, and, if late enough, nighthawks. Fork-tailed flycatchers swept by scores round the vortex of insects, while a fluttering host of kiskadees, tanagers, anis, thrushes, and wrens gleaned as best they could from grass-top or branch. In ten minutes the whole flight had vanished. Any queen termite which ran that gauntlet safely, deserved to found her colony without further molestation.

Although I might have stalked and watched the white campañeros for a week past, yet whenever there came to ear the anvil-like kong! kang! or the ringing, sonorous kaaaaaaaaaaang! of a bell-bird three miles away, I always stopped work and became one great ear to this jungle angelus.

One could watch the changing seasons of the great tropical jungle from the same wonder windows of Kalacoon. A dull rose suffused the tree-tops, deepening day by day, and finally the green appeared, picked out everywhere by a myriad blossoms--magenta, mauve, maroon, carmine, rose, salmon-pink. Yet the glass showed only top-gallant foliage of wilted, parti-colored 
leaves. Illusion upon illusion: these were not wilted, but newborn leaves which thus in their spring glory rivaled our autumnal tints. One never forgot the day when the first mora burst into full bloom - a great mound of lavender pigment, swung nearly two hundred feet in midair, dominating all the surrounding jungle growth. This was the lush, prodigal way in which the tropics announced spring.

Whether I had spent the day in hard tramping or stalking in the jungle, or at my laboratory table trying to disentangle the whys and wherefores from the physical skein of my specimens, toward sunset I always went down to the cement floor of an orchid-house long fallen in decay. This was under the open sky, and from this spot on the highest hilltop in all this region, I watched the end of the day.

No sunset should ever be described, and the Kalacoon sunsets were too wonderful for aught but wordless reverence. They were explosions of wild glory, palettefuls of unheard-of pigments splashed across the sky, and most bewildering because they were chiefly in the east or north. This evening on which I write was sealed with a sunset of negligible yellow, but 
the east was a splendor of forest fires and minarets, great golden castles and pale-green dragons and snow-capped mountains all conceived and molded from glorious tumbled cloudmasses, and ultimately melting back into them again. The moriche orioles met the beauty of the heavens with their silver notes, and as the sky cooled, there arose the sweet, trilled cadence of the little tinamou heralding the voices of night. The silvery collared nighthawks began their eternal questioning who-are-you! who-areyou! and the coolness banished all thought of the blistering sunshine now pouring down upon the waters of the Pacific.

Not until later, when the night-life was fairly under way, and all the beings of the sun hidden and asleep, did the deep bass rumble of the big toads commence, and the tinkling chorus of the little frogs. Last of all came the essence of the nocturnal-the sound furthest removed from day. All other voices seemed to become for an instant hushed, and the poor-me-one spoke-a wail which rose, trembled, and broke into a falling cadence of hopeless sighs.

And now, with the crescent moon writing its beliograph cipher upon the water, a new sound 
arose, low and indistinct, lost for a moment, then rising and lost again. Then it rang out rich and harmonious, the full-throated paddling chanty of a gold-boat of blacks coming down river with their tiny pokes of glittering dust. It tore at the heart-strings of memory, and in its wildness, its sad minor strain, was strangely moving. The steersman set the words and in high, quavering tones led the chorus, which broke in, took up the phrase, different each time, and repeated it twice over, with a sweet pathos, a finality of cadence which no trained white chorus could reproduce.

There was much of savage African rhythm in these boat-songs, and instead of the drum of the Zulus came the regular thump-thump, thumpthump, of paddles on the thwarts. They were paddling slowly, weary and tired after a long day of portaging, passing with the tide down to Bartica. Then on to a short, exciting period of affuence in Georgetown, after which they would return for another six months in the gold bush. They were realizing their little El Dorados in these very waters more successfully than Sir Walter Raleigh was able to do.

I have said that the wonder windows would 


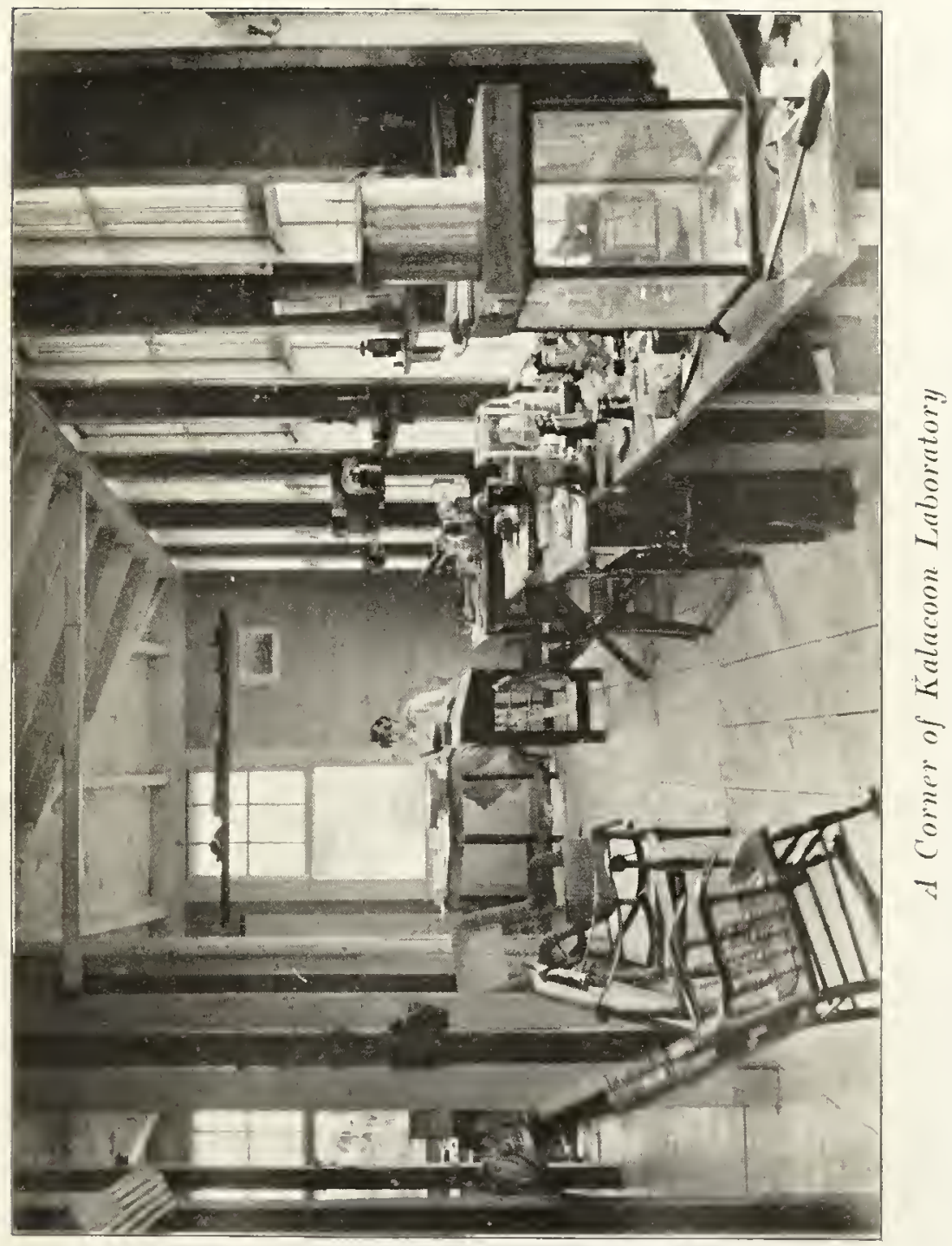



take one to the Far East; and hardly had the gold-boat passed out of hearing when the neverto-be-forgotten beat-beat-beat-beat of a tom-tom rose without hint or introduction, and straightway the cecropias became deodars and the palms dwarfed to pipuls and sal, and the smells of the Calcutta bazaars and the dust of Agra caravans lived again in that sound.

A voice in soft Hindustani tones was heard below-the low, inarticulate phrases framing themselves into a gentle honk-honka, honk, honkhonka. Then, still out of sight, came a voice on the stairway: "Salaam, sahib, will sahib come see dance and see wedding?"

The sahib would; and I followed the wavering lantern of the bride's father down the steep, rocky path which, at the water's edge, turned toward the half-dozen huts of the East Indians.

For a week the coolie women had done no work in the fields, but had spent much of their time squatted in chanting circles. I learned that a marriage was to take place, and, to my surprise, the bride proved to be Budhany, the little child who brought us milk each day from the only cow south of the Mazaruni. Another day, as I passed to the tent-boat, I saw the 
groom, naked save for his breech-clout, looking very foolish and unhappy, seated on a box in the center of the one short street, and surrounded by six or eight women, all who could reach him vigorously slapping him and rubbing him with oil from head to foot. Every evening, to the dull monotone of a tom-tom, the shrill voices of the women were carried up to Kalacoon; but tonight a louder, more sonorous drum was audible and the moaning whine of a short, misshapen Hindi violin.

Amid a murmur of salaams we seated ourselves on grocery boxes while the audience ranged itself behind. In the flickering light of torches I recognized my friends one by one. There was Guiadeen who had brought in the first ant-eater; he seated us. Then Persaid of the prominent teeth, who had tried to cheat me of a sixpence already paid for a mouse-opossum with her young. Persaïd gave us only a hasty salaam, for he was a very busy and fussy master of ceremonies. From behind came the constant droning chant of the priest, lingeringly reading from a tattered Pali volume, an oil torch dripping close to his white turban. His voice was cracked, but his intonation was careful and his 
words well articulated. The day before we had greeted him and chaffingly admonished him to marry them well.

"God only could promise that," he had replied with a quick smile.

Others of the little village I knew: Rahim the milkman, and Mahabol, with the head and beard of a Sikh on the legs of a Bengalee, and a thin Bengalee at that. The audience which pressed close behind, looked and smelled Calcutta and Darjeeling, and a homesickness which was pain came over me, to be once more among the great Himalayas. The flickering torch showed all my retinue threaded along the outer rim of onlookers; my following who formed a veritable racial tower of Babel. There was Nupee the Akawai, and Vingi the Machusi and Semmi the Wapiano-red Indians from forest and savannah. Near them the broad, black African face of little Mame, all eyes and mouth in the dim light. Then de Freitas the Portuguese, and all the others of less certain lineage.

Meanwhile Persaïd had brought forth an oily, vile-smelling liquid with which he coated a square yard of earth, and then with pounded maize and rice he marked out a mystic figure- 
two squares and diagonals. As the ceremony went on I lost much of the significance, and the coolies themselves seemed very vague. They were all of low caste and preserved more of the form than knowledge of the intricate rites.

We were at the groom's end of the absurd street, and before long Madhoo himself appeared and was led a few steps away by his female tormentors. This time they scrubbed and washed and rinsed him with water, and then dressed him in a soft white waist-cloth draped coolie-wise. Then a long tight-sleeved pink dress was pulled with much difficulty over his head. Madhoo now looked like a woman dressed in a fashion long extinct. Next, a pink turban was wound wonderfully about his head and he was led to one side of the rice figure, where he sat down on a low stool.

Sam, my black factotum, sat close to me, translating when my slender knowledge of Hindustani gave out. Suddenly he stopped abruptly in the middle of a sentence. I saw that he was staring at the groom, the whites of his eyes glistening in astonishment.

"Chief," he whispered at last, "see where my socks, my shoes!" 
And sure enough, we saw Persaïd pulling the purple-striped socks, which had been Sam's delight, over the unaccustomed ankles of the groom. These were followed by cheap white tennis shoes, causing another ejaculation on the part of Sam.

"Hello, shoes!" I heard him murmur to himself.

Sam always personified those parts of his environment which touched his feelings most deeply, whether clothes, curries, thorns, or gravitation. When unloading the tent-boat a few nights before, he had left his shoes on the bank; and during a trip up the hill to Kalacoon they had vanished. For a moment I was not sure that Sam, like the hero in some melodrama, would not rise and forbid the marriage. Then I heard him chuckling and knew that his sense of humor and regard for our evening's entertainment had nobly overcome what must have been a very real desire to possess again those gorgeous articles of attire. And, besides, I felt sure that the morrow would witness a short, pithy interview regarding these same articles, between Sam and either Madhoo or Persaïd.

Clad now in this added glory, the groom 
waited, like the tethered heifer, looking furtively at his circle of well-wishers. His little, shriveled mother came and squatted close behind him, toboggan-fashion, and flung a fold of her cloth over his back. Then she waved various things three times over his head: a stone grain-crusher, a brass bowl of water, and tossed rice and pellets of dough in the four directions. Red paint was put on her toes and feet and caste marks on her son.

Meanwhile the dancer had begun and his musicians were in full swing; but of these I shall speak later. The groom was backed into an elaborate head-dress, a high, open-work affair of long wired beads with dangling artificial flowers. First it was placed on the mother's head and then on the turban of the long-suffering young man. An outflaring of torches and a line of white-robed and turbaned coolies from the other end of the street of six houses roused the groom and his friends to new activity. He climbed upon one of the men, straddling his neck, and what appeared to be a best man, or boy, mounted another human steed. They were then carried the few feet to the house of the bride, the shiny, black-rubber soles of the filched 
tennis shoes sticking absurdly out in front. A third man carried a bundle,---very small, to which no one seemed to attach much importance,-which was said to contain clothes for the bride.

After an undignified dismounting, the groom squatted by a new rice-and-maize square and removed his shoes and socks, to his own evident relief and Sam's renewed excitement. Then coppers passed to the priest and many symbolic gifts were put in the groom's hands; some of these he ate, and others he laid in the square. Whenever money passed, it was hidden under sweet-smelling frangipani blossoms, or templeflowers, as they are called in India. The bride's mother came out and performed numerous rites to and around the groom; finally, a small person in white also achieved one or two unimportant things and disappeared.

While we waited for some culminating event, the groom stood up, skilfully lit a cigarette through the meshes of the dangling head-dress, and walked with his friends to the porch of the opposite house, where he squatted on the earthen floor in the semi-darkness. Then came Persaid and announced, "Marriage over; man wait until 
daylight, then carry off bride to honeymoon house"-the 'dobe hut plastered all over with the imprints of hundreds of white, outspread fingers and palms.'

The marriage over! 'This was a shock. The critical moment had come and passed, eluding us, and Budhany, the little bride, had appeared and vanished so hurriedly that we had not recognized her.

The dancer had throughout been the focus of interest for me. There was no perfunctory work or slurring over of the niceties of his part, and his sincerity and absorption inspired and stimulated his four assistants until they fairly lost themselves in abandon to the rhythm and the chant. His name was Gokool and he had come up from one of the great coastal sugar plantations. Nowhere outside of India had I seen such conscientious devotion to the dancer's work.

Rammo the tent-boat captain played the cretinous violin; he it was who never tired of bringing us giant buprestids and rails' eggs, and whose reward was to watch and listen to our typewriter machine through all the time that he dared prolong his visit to our laboratory. Dusráte played the tiny clinking cymbals; Mattora, 
he of the woman's voice, held the torch always close before the dancer's face; while the drummer-the most striking of them all-was a stranger, Omeer by name. Omeer, with the double-ended tom-tom in a neck-sling, followed Gokool about, his eyes never leaving the latter's face. Little by little he became wholly rapt, absorbed, and his face so expressive, so working with emotion, that I could watch nothing else.

Gokool was a real actor, a master of his art, with a voice deep, yet shifting easily to falsetto quaver's, and with the controlled ability of emphasizing the slightest intonations and delicate semi-tones which made his singing full of emotional power. He got his little orchestra together, patting his palms in the tempo he wished, then broke suddenly into the wailing, dynamic, abrupt phrases which I knew so well. Had not my servants droned them over my camp-fires from Kashmir to Myitkyina, and itinerant ballad-singers chanted them from Ceylon to the Great Snows!

Gokool's dress was wide and his skirt flaring, so that, when he whirled, it stood straight out, and it was stiff with embroidery and scintillating with tinsel. From his sleek, black hair 
came perfume, that musky, exciting scent which alone would summon India to mind as with a rub of Aladdin's lamp. His anklets and bracelets clinked as he moved; and suddenly, and to our Western senses always unexpectedly, he would begin the swaying, reeling motion, almost that of a cobra in hood. Then after several more phrases, chanted with all the fire and temperamental vigor which marks Hindu music, he would start the rigid little muscular steps which carried him over the ground with no apparent effort, though all the time he was wholly tense and working up into that ecstasy which would obsess him more and more. His songs were of love and riches and war, and all the things of life which can mean so little to these poor coolies.

Exhaustcd at last, he stopped; and I found that I too suddenly relaxed-that I had been sitting with every muscle tense in sympathy. Grokool came and gave me a salaam, and as he turned away for a hand-hollowed puff of hemp I spoke a little word of thanks in his own tongue.

He looked back, not believing that he had heard aright. I repeated it and asked if he 
knew "Dar-i-Parhadoor," this being my phonetic spelling of a certain ballad of ancient India.

"Koom, sahib," he said; and kneeling touched my foot with his head.

Then we talked as best we could, and I found he was from the Hills, and knew and adored the Parhadoor, and was even more homesick for the Great Snows than I. But once something had snapped in his head and he could not work in the sun, and could dance but rarely; so now he earned money for his daily rice only and could never return.

Then he gathered his musicians once more and sang part of the majestic Parhadoor, which is full of romance and royal wars, and has much to do with the wonders of the early Rajputs. And he sang more to me than to the groom, who neither looked nor listened, but kept busy with his clothes.

Out of all the pressing throng a little coolie boy came and squatted close, and his eyes grew large as he listened to the tale, and from time to time he smiled at me. He had once brought me a coral snake, but I could not call him by name. Now I knew him for the one unlike 
the rest,-worthy perhaps of a place in my memory roll of supercoolies,-who worked at weeding day after day, like the rest of the men, but who thought other thoughts than those of Mahabol and Guiadeen. I wished I had known of him sooner.

So Gokool sang to us two, the coolie boy and me, a song of ancient India, and danced it by moonlight here in this American jungle, and I dotted his dancing circle with pence, and a few bits, and even a shilling or two. And Gokool thanked me with dignity. And his face will long remain vivid, tense with feeling, forgetful of all but the loud-cadenced phrases, the quavering chant which broke in and out of falsetto so subtlely that no Western voice may imitate it. And I like to think that he enjoyed dancing for a sahib who loved Lucknow and the old ballads. And so we parted.

After I cached the vampire lantern behind its intrenched bulwark of books and magazines, I leaned far out of a window and thought over the night's happenings. It was long after midright, and the steady throb of the tom-tom still kept rhythm with the beat of my temples, and 
I gave myself up to the lure of the hypnotic monotone.

One thought kept recurring-of the little girl far back in the dark depths of the wattled hut. She was so little, so childish, and her part that evening had been so slight and perfunctory, not as much as that of any of the other women and girls who had slovenly performed the halfunderstood rites. She had brought us milk regularly, and smiled when we wished salaam to her.

She knew less of India than I did. Guiana, this alien land, as humid and luxuriant as the Great Plains were dry and parched-this was her native country. And this evening was her supreme moment; yet her part in it had not seemed fair. She would have liked so much to have worn that pink dress which made her future husband a caricature; she would have adored to place the shining, tinseled head-dress on her black hair-more with a child's delight than a woman's. And now she would live in a house of her own, and not a play-house, and obey this kind-faced young man-young, but not in comparison with her, whose father he could have been. And she would have anklets 
and bracelets and a gorgeous nose-button if he could save enough shillings,-I almost said rupees,-and ultimately she would go and cut grass with the other women, and each day take her little baby astride her hip down to the water and wash it, as she, so very short a time ago, had been washed.

And so, close to the wonder windows, we had seen a marriage of strange peoples, who were yet of our own old Aryan stock; whose ceremonies were already ancient when the Christians first kept faith, now transported to a new land where life was infinitely easier for them than in their own overcrowded villages; immigrants to the tropical hinterland where they rubbed elbows with idle Africans and stolid Red Indians. And I was glad of all their strange symbolic doings, for these showed imagination and a love of the long past in time and the distant in space.

I wished a good wish for Budhany, our little milkmaid, and forgot all in the sound, dreamless sleep which comes each night at Kalacoon. 


\section{VIII}

\section{THE CONVICT TRAIL}

I Am thinking of a very wonderful thing and words come laggardly. For it is a thing which more easily rests quietly in the deep pool of memory than stirred up and crystalized into words and phrases. It is of the making of a new trail, of the need and the planning and the achievement, of the immediate effects and the possible consequences. For the effects became manifest at once, myriad, unexpected, some sinister, others altogether thrilling and wholly delightful to the soul of a naturalist. And now, many months after, they are still spreading, like a forest fire which has passed beyond control. Only in this case the land was no worse and untold numbers of creatures were better off because of our new trail.

Of the still more distant consequences I cannot write, for the book of the future is tightly sealed. But we may recall that a trail once 
was cut through coarse, high grass and belts of cedar, which in time became the Appian Way. And a herd of aurochs breasting in single file dense shrubby oaks and heather toward a salt lick may well have foreshadowed Regent Street; the Place d'Etoile was perhaps first adumbrated by wild boars concentrating on a root-filled marsh. And why should not the Indian trail which became a Dutch road and our Fifth Avenue, have had its first hint in a moose track down the heart of a wooded island, leading to some hidden spring!

We left our boats stranded on the Mazaruni River bank and climbed the steep ascent to our new home in the heart of British Guiana. Our outfit was unpacked, and the laboratory and kitchen and bedrooms in the big Kalacoon house were at last more than names.

And now we surveyed our little kingdom. One path led down to our boats, another meandered eastwards through the hills. But like the feathered end of the magnetic arrow, we drifted as with one will to the south. Here at the edge of our cleared compound we were confronted by a tangle. It was not very hightwenty feet or so--but dense and unbroken. 
Like newly trapped creatures we paced back and forth along it looking for an opening. It was without a break. We examined it more closely and saw a multitude of slender, graceful cane stems hung with festoons and grasslike drapery. One of us seized a wisp of this climbing grass and pulled downward. When he dropped it his hand dripped blood. He might as well have run a scroll saw over his fingers. The jungle had shown its teeth.

We laughed and retreated to the upper floor for consultation. The sight we saw there decided us. In the distance "not too far," to use the hopelessly indefinitc Guiana vernacular, high over the tumbled lower growths towered the real jungle- the high bush. This was the edge of that mighty tropical ocean of foliage, that sea of life with its surface one hundred, two hundred feet above the earth, strctching unbroken to the Andes: leagues of unknown wonderland. And here we were, after thousands of miles of voyaging to study the life of this great jungle, to find our last few yards blocked by a mass of vegctation. There was no dissenting voice. We must cut a trail, and at once, straight to the jungle. 
Before we begin our trail, it will be wise to try to understand this twenty-foot tangle, stretching almost a mile back from Kalacoon. Three years before it was pure jungle. Then man came with ax and saw and fire and one by one the great giants were felled-mora, greenheart, crabwood-each crashing its way to earth after centuries of upward growth. The underbrush in the dark, high jungle is comparatively scanty. Light-starved and fungus-plagued, the shrubs and saplings are stunted and weak. So when only the great stumps were left standing, the erstwhile jungle showed as a mere shambles of raw wood and shriveled foliage. After a time fire was applied, and quickly, as in the case of resinous trees, or with long, slow smolderings of half-rotted, hollow giants, the huge boles were consumed.

For a period, utter desolation reigned. Charcoal and gray ash covered everything. No life stirred. Birds had flown, reptiles and insects made their escape or succumbed. Only the saffron-faced vultures swung past, on the watch for some half-charred creature. Almost at once, however, the marvelous vitality of the tropical vegetation asserted itself. Phoenix-like, from 
the very heart of the ashes, appeared leaves of strange shape and color: Stumps whose tissues seemed wholly turned to charcoal sent forth adventitious shoots, and splintered boughs blossomed from their wounds. Now was the lowest ebb of the jungle's life, when man for the success of his commercial aims, should take instant advantage. But plans miscarried and the ruin wrought was left to nature.

The destruction of the jungle had been complete and the searing flames had destroyed all forest seeds. In their place, by some magic, there sprang up at once a maze of weeds, vines and woody shrubs, reeds, ferns and grasses, all foreign to the dark jungle and whose nearest congeners were miles away. Yet here were their seeds and spores, baffling all attempts at tracing their migration or the time they had laid dormant.

When we had begun to penetrate this newborn tangle we found it possible, by comparing various spots, to follow its growth in past time. The first things to appear in the burned jungle area were grasses or grass-like plants and prostrate vines. These latter climbed over the fallen tree-trunks and covered the charred stumps with 
a glory of blossoms-white convolvulus gleaming everywhere, then pale yellow allamandas, and later, orchid-like, violet, butterfly peas which at first flowered among the ashes on the ground, but climbed as soon as they found support. Little by little, a five-finger vine flung whole chains of bloom over stumps, logs and bushes, a beautiful, blood-red passion flower, whose buds looked like strings of tiny Chinese lanterns.

Soon another type of plant appeared, with hollow and jointed stems, pushing out fans of fingered leaves, swiftly, wasting no time in branching, but content with a single spike piercing up through strata of grass and reeds, through shrubs and bushes until it won to the open sky. This was the cecropia or trumpet tree, falsely appearing firm and solid stemmed, but quite dominant in the neglected tangle.

We started early one morning with small axes and sharp machetes, and single file, began to cut and hew and tear a narrow trail southward. For some distance we found almost a pure culture of the cecropia trees, through which we made rapid progress which aroused entirely false hopes. It was a joy to crash obliquely 
through the crisp hollow stems at one blow from our great knives. The second man cut again at the base and the rest took the severed stems and threw or pushed them to one side, cutting away any smaller growths. We soon learned to be careful in handling the stems for they were sanctuary for scores of a small stinging ant, whose race had practiced preparedness for many generations and who rushed out when the stem was split by cutlass or ax.

As we went on we learned that differences in soil which were not apparent when the great jungle covered everything, had now become of much importance. On high sandy spots the cecropias did not get that flying start which they needed for their vertical straightaway dash. Here a community of hollow reeds or bamboo grass appeared from no one knows where. They had grown and multiplied until their stems fairly touched one another, forming a dense, impenetrable thicket of green, silicious tubes eight to twelve feet in length. These were smooth and hard as glass and tapered beautifully, making wonderfully light and strong arrows with which our Akawai Indians shot fish. Slow indeed was our progress through this. The 
silica dulled and chipped our blades and the sharp points of the cut stems lamed us at a touch.

But whatever the character of the vegetation, whether a tangle of various thorny nightshades, a grove of cecropias, or a serried phalanx of reeds, the terrible razor-grass overran all. Gracefully it hung in emerald loops from branch to branch, festooning living foliage and dead stump alike, with masses of slender fronds. It appeared soft and loose-hung as if one could brush it away with a sweep of the hand. But it was the most punishing of all living things, insidiously cutting to the bone as we grasped it, and binding all this new growth together with bands more efficient than steel.

An age-old jungle is kind to the intruder, its floor is smooth and open, one's footsteps fall upon soft moss, the air is cooled and shadowed by the foliage high overhead. Here, in this mushroom growth of only three years, our progress became slower and ever more difficult. Our hands bled and were cut until we could barely keep them gripped about the cutlass handles; our trail opened up a lane down which poured the seething heat of the sun's direct rays; thorns 
penetrated our moccasins and ants dropped down our necks and bit and stung simultaneously with opposite ends of their anatomy. Five minutes' chopping and hacking was all that the leader could stand, who would then give way to another. Fifty yards of a narrow lane represented our combined efforts the first day.

Direction was a constant source of trouble. Every three or four feet we had to consult a compass, so confusing was the tangle. Sudden gullies blocked us, a barren, half-open, sandy slope cheered us for a few yards. It was nature's defense and excelled any barbed-wire entanglement I have ever seen at the battle-front.

Once I came to a steep concealed gully. The razor-grass had been particularly bad, giving like elastic to blows of the cutlass and then flying back across my face. I was adrip with perspiration, panting in the heat when I slid part way down the bank, and chopping away a solid mass of huge elephant's ears, uncovered a treetrunk bridging the swamp. It brought to mind the bridge from Bad to Worse in the terrible Dubious Land. Strange insects fled from the great leares, lizards whisked past me, hummingbirds whirred close to my face-the very sound 
seeming to increase the heat. I slipped and fell off the log, splashing into the hot water and warm mud, and sat in it for a while, too fagged to move. Then the rest of the party came up and we clambered slowly to the top of the next rise, and there caught sight of the jungle's edge, and it seemed a trifle nearer and we went on with renewed courage. Shortly afterwards two of us were resting in a patch of reeds while the third worked some distance ahead, when there came a sudden low growl and rush. Instinctively we rose on the instant, just in time to see a jaguar swerve off on one side and disappear in a swish of swaying reed stems. I have never known one of these animals to attack a man, and in this case the jaguar had undoubtedly heard but not scented us, and the attack ceased the moment we proved to be other than deer or similar prey. The incident had come and passed too swiftly for thought, but now when we realized that this was a bit of the real wild life of the jungle, our enthusiasm never flagged, and we kept steadily at the heart-breaking work, resting only now and then for our cuts to heal.

Then a government official who was our 


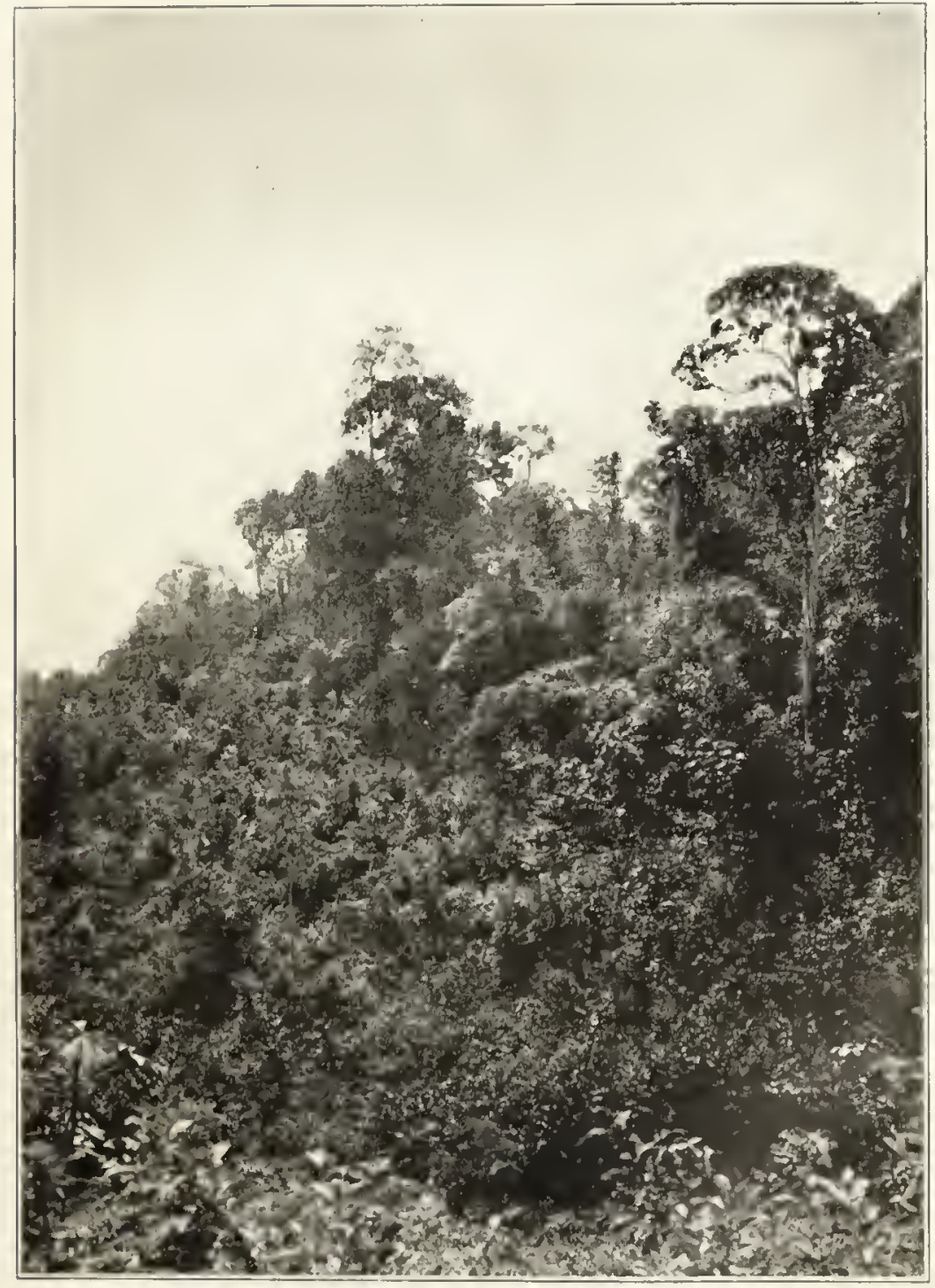

The Edge of the Jungle 

guest, took pity on us, and for science' sake, obtained special dispensation. One morning we went out and found in our compound several huge, blue-uniformed policemen, who saluted and with real black magic, produced twenty convicts-negroes and coolies-armed with cutlasses. So began the second phase of what we now named the Convict Trail. We had already fought our painful way through a half-mile of the terrible maze, and now we heartily welcomed this new aid, whether good-natured murderers, and burglars, or like Sippy, Slorg and Slith, mere thieves. We watched them strip to their black skins and begin a real assault. On a front of ten to fifteen feet, the tangle fairly dissolved before our eyes, and their great tough palms and soles made little moment of the razorgrass and thorns. In one of the slight-bodied coolies, whose task was to clear away the cut débris, I recognized Ram Narine, whose trial had been the cause of my traveling another trail.

With my friend, Hope, an honest forger, I went on far ahead and laid the course for the jungle. In especially dense parts we climbed to the summit of great jungle stumps and 
stretched a white sheet to guide the oncoming trail cutters.

Day after day the score of convicts returned with their guards and at last we saw the path unite with an old game and Indian trail in the cool shade of the jungle, and Kalacoon was in direct contact with the great tropical forest itself. I have passed lightly over the really frightful pain and exhaustion which we experienced in the initial part of this work, and which emphasized the tremendous difference between the age-old jungle untouched by man, and the terrible tangle which springs after he has destroyed the primeval vegetation.

After this came our reward, and never a day passed but the trail yielded many wonderful facts. The creatures of the wilderness soon found this wide swath, and used it by day and night, making it an exciting thing for us to peer around a corner, to see what strange beings were sitting or feeding in our little street.

Before the trail was quite completed, it yielded one of the most exciting hunts of our trip-the noosing of a giant bushmaster-the most deadly serpent of the tropics. Nupeemy Akawai Indian hunter, two nestling trogons 
and Easter eve-these things led to the capture of the Master of the Bush: For nothing in the tropics is direct, premeditated.

My thoughts were far from poisonous serpents when Nupee came into our Kalacoon laboratory late on a Saturday afternoon. Outdoors he had deposited the coarser game intended for the mess, consisting, today, of a small deer, a tinamou or maam and two agoutis. But now with his quiet smile, he held out his lesser booty, which he always brought in to me, offering in his slender, effeminate hands his contribution to science. Usually this was a bird of brilliant plumage, or a nestful of maam's eggs with shells like great spheres of burnished emeralds. These he would carry in a basket so cunningly woven from a single palm frond that it shared our interest in its contents. Today, he presented two nestling trogons, and this was against rules. For we desired only to know where such nests were, there to go and study and photograph.

"Nupee,--listen! You sabe we no want bird here. Must go and show nest, eh?"

"Me sabe."

Accompanied by one of us, off he started 
again, without a murmur. In the slanting rays of the sun he walked lightly down the trail from Kalacoon as if he had not been hunting since early dawn. An hour passed and the sun swung still lower when a panting voice gasped out:

"Huge labaria, yards long! Big as leg!"

The flight of queen bees and their swarms, the call to arms in a sleeping camp creates somewhat the commotion that the news of the bushmaster aroused with us. For he is really what his name implies. What the elephant is to the African jungles and the buffalo to Malaysia, this serpent is to the Guiana wilderness. $\mathrm{He}$ fears nothing-save one thing, hunting ants, before which all the world flees. And this was the first bushmaster of the rainy season.

Nupee had been left to mount guard over the serpent which had been found near the trogon tree. Already the light was failing; so we walked rapidly with gun, snake-pole and canvas bag. Parrakeets hurtled bamboowards to roost; doves scurried off and small rails flew from our path and flopped into the reeds. Our route led from the open compound of Kalacoon, through the freshly cut Convict Trail, toward 
the edge of the high bush, and we did not slacken speed until we were in the dim light which filtered through the western branches.

At the top of the slope we heard a yell-a veritable Red Indian yell-and there our Akawai hunter was dancing excitedly about, shouting to us to come on. "Snake, he move! Snake, he move!" We arrived panting, and he tremblingly led me along a fallen tree and pointed to the dead leaves. I well knew the color and pattern of the bushmaster. I had had them brought to me dead and had killcd them myself, and I had seen them in their cage behind glass. But now, though I was thinking bushmaster and looking bushmaster, my eyes insisted on registcring dead leavcs. Eager as I was to bcgin operations before darkness closed down, it was a full three minutes before I could honestly say, "This is leaf; that is snake."

The pattern and pigment of the cunningly arranged coils were that of the jungle floor, anywhere; a design of dead leaves, reddishycllow, pinkish, dark-brown, etched with mold, fungus and decay, and with all the shadows and high lights which the heaped-up plant tissues throw upon one another. In the center of this 
dread plaque, this reptilian mirage, silent and motionless, rested the head. I knew it was triangular and flattened, because I had dissected such heads in times past, but now my senses revealed to me only an irregularity in the contour, a central focus in this jungle mat, the unraveling of which spelt death.

It was a big snake, seven or eight feet long, and heavy bodied-by no means a one-man job. Again we carefully examined the screw-eyes on the pole, and each looked behind for a possible line of escape.

I quickly formed my method of attack. Nupee was sent to cut forked sticks, but his enthusiasm at having work to do away from the scene of immediate conflict was so sincere that he vanished altogether and returned with the sticks only when our shouts announced the end of the struggle. An Indian will smilingly undergo any physical hardship, and he will face any creature in the jungle, except the bushmaster.

We approached from three sides, bringing snake-pole, free noose and gun to bear. Slowly the noose on the pole pushed nearer and nearer. I had no idea how he would react at the attack, 
whether he would receive it quietly, or, as I have seen the king cobra in Burma, become enraged and attack in turn.

The cord touched his nose, and he drew back close to some bushy stems. Again it dangled against his head, and his tongue played like lightning. And now he sent forth the warning of his mastership - a sharp rohirrrr! and the tip of his tail became a blur, the rough scales rasping and vibrating against the dead leaves, and giving out a sound not less sharp and sinister than the instrumental rattling of his near relatives.

For a moment the head hung motionless, then the noose-man made a lunge and pulled his cord. The great serpent drew back like a flash, and turning, undulated slowly away toward the darker depths of the forest. There was no panic, no fear of pursuit in his movements. $\mathrm{He}$ had encountered something quite new to his experience, and the knowledge of his own power made it easy for him to gauge that of an opponent. He feared neither deer nor tapir, yet at their approach he would sound his warning as a reciprocal precaution, poison against hoofs. And now, when his warning had no effect on 
this new disturbing thing, he chose dignifiedly to withdraw.

I crept quickly along on one side and with the gun-barrel slightly deflected his course so that he was headed toward an open space, free from brush and bush-ropes. Here the poleman awaited him, the noose spread and swaying a few inches from the leaves. Steadily the snake held to his course, and without sensing any danger pushed his head cleanly into the circle of cord. A sudden snap of the taut line and pandemonium began. The snake lashed and curled and whipped up a whirlpool of débris, while one of us held grimly on to the noose and the rest tried to disentangle the whirling coils and make certain of a tight grip close behind the head, praying for the screw-eyes to hold fast. Even with the scant inch of neck ahead of the noose, the head had such play that I had to pin it down with the gun-barrel before we dared seize it. When our fingers gained their safe hold and pressed, the great mouth opened wide, a gaping expanse of snowy white tissue, and the inch-long fangs appeared erect, each draped under the folds of its sheath like a rapier outlined beneath a courtier's cloak. 
When once the serpent felt himself conquered, he ceased to struggle; and this was fortunate, for in the dim light we stumbled more than once as we sidled and backed through the maze of lianas and over fallen logs.

Nupee now appeared, unashamed and wideeyed with excitement. He followed and picked up the wreck of battle-gun, hats and bags which had been thrown aside or knocked off in the struggle. With locked step, so as not to wrench the long body, we marched back to Kalacoon. Now and then a great shudder would pass through the hanging loops and a spasm of muscular stress that tested our strength. It was no easy matter to hold the snake, for the scales on its back were as rough and hard as a file, and a sudden twist fairly took the skin off one's hand.

I cleaned his mouth of all dirt and débris, and then we laid him upon the ground and, without stretching, found that he measured a good eight feet and a half. With no relaxing of care we slid him into the wired box which would be his home until he was liberated in his roomier quarters in the Zoölogical Park in New York.

Close to the very entrance of the Convict 
Trail behind Kalacoon stood four sentinel trees. Every dar we passed and repassed them on the way to and from the jungle. For many days we paid rery little attention to them, except to be grateful for the shade cast by their dense foliage of glossy leares. Their trunks were their most striking feature, the bark almost concealed by a maze of beautifully colored lichens, different forms orerlapping one another in many places, forming a palimpsest of grar, white, pink, maure and lilac. One day a streaked flycatcher chose the top of a branch for her nest, and this we watched and photographed and robbed for science' sake, and again we thought no more of the four trees.

Late in April, howerer, a change came orer the trees. The leares had been shed some time in January and the fallen foliage formed a dry mass on the ground which crackled under foot. Now each branch and twig began to send out clusters of small buds, and one day,-a week after Easter,- these burst into indescribable glory. Erery lichened bough and branch and twig was lined with a soft mass of bloom, clear, bright cerise, which reflected its brilliance on the foliage itself. After two days a rain of stamens 
began and soon the ground beneath the trees was solid cerise, a carpet of tens of thousands of fallen stamens, and within the length of a foot on one small branch were often a score of blooms. This feast of color was wonderful enough, and it made us want to know more of these trees. But all the information we could glean was that they were called French cashew. Yet they had not nearly finished with the surprises they had in store. A hummingbird or two was not an uncommon sight along the trail at any time, but now we began to notice an increase in numbers. Then it was observed that the tiny birds seemed to focus their fight upon one part of the clearing, and this proved to be the four cashew trees.

The next few days made the trees ever memorable: they were the Mecca of all the hummingbirds in the jungle. In early morning the air for many yards resounded with a dull droning, as of a swarming of giant bees. Standing or sitting under the tree we could detect the units of this host and then the individuals forced themselves on our notice. Back and forth the hummers swooped and smung, now poising in front of a mass of blossom and probing deeply 
among the stamens, now dashing off at a tangent, squeaking or chattering their loudest. The magnitude of the total sound made by these feathered atoms was astounding; piercing squeaks, shrill insect-like tones, and now and then a real song, diminutive trills and warbles as if from a flock of song birds a long distance away. Combats and encounters were frequent, some mere sparring bouts, while, when two would go at it in earnest, their humming and squeaks and throb of wings were audible above the general noise.

This being an effect, I looked for the cause. The massed cerise bloom gave forth comparatively little perfume, but at the base of each flower, hidden and protected by the twenty score densely ranked stamens, was a cup of honey; not a nectary with one or two delicately distilled drops, but a good thimbleful, a veritable stein of liquor. No creature without a long proboscis or bill could penetrate the chevauxde-frise of stamens, and to reach the honey the hummingbirds had to probe to their eyes. They came out with forehead well dusted with pollen and carried it to the next blossom. The destiny of the flower was now fulfilled, the pot of 
honey might dry up, the stamens rain to the earth and the glory of Tyrian rose pass into the dull hues of decay.

Day after day as we watched this kaleidoscope of vegetable and avian hues, we came to know more intimately the units which formed the mass. 'There were at least fifteen species and all had peculiarities of flight and plumage so marked that they soon became recognizable at sight.

After our eyes had become accustomed to specific differences in these atoms of birds we began to notice the eccentricities of individuals. This was made easy by the persistence with which certain birds usurped and clung to favorite perches. One glowing hermit clad in resplendent emerald armor selected a bare twig on a nearby shrub and from there challenged every hummer that came in sight; whether larger, smaller or of his own kind made no difference. He considered the cashew trees as his own special property and as far as his side of them went he made good his claim. I have never seen such a concentration of virile combative force in so condensed a form.

In some such way as vultures concentrate 
upon carrion, so news of the cashew sweets had passed through the jungle. Not by any altruistic agency we may be certain, as we watch the selfish, irritable little beings, but by subtile scent, or as with the vultures, by the jealous watching of each other's actions. I observed closely for one hour and counted one hundred and forty-six hummingbirds coming to the tree. During the day at least one thousand must visit it.

They did not have a monopoly of the cashew manna, for now and then a honey-creeper or flower-pecker flew into the tree and took toll of the sweets. But they were scarcely noticeable. We had almost a pure culture of hummingbirds to watch and vainly to attempt to study, for more elusive creatures do not exist. Convict Trail revealed no more beautiful a sight than this concentration of the smallest, most active and the most gorgeous birds in the world.

Such treats-floral and avian-were all that might be expected of any tree, but the cashews had still more treasures in store. The weeks passed and we had almost forgotten the flowers and hummingbirds, when a new odor greeted us, the sweet, intense smell of overripe fruit. We 
noticed a scattering of soft yellow cashews fallen here and there, and simultaneously there arrived the hosts of fruit-eating birds. From the most delicate turquoise honey-creepers to great red and black grosbeaks, they thronged the trees. All day a perfect stream of tanagers - green, azure and wine-colored-flew in and about the manna, callistes and silver-beaks, dacnis and palm tanagers. And for a whole week we gloried in this new feast of color, before the last riddled cashew dropped, to be henceforth the prize of great wasps and gauze-winged flies, who guzzled its fermented juice and helped in the general redistribution of its flesh--back to the elements of the tropic mold, to await the swarms of fingering rootlets, a renewed synthesis-to rise again for a time high in air, again to become part of blossom and bird and insect.

It was along this Convict 'Trail that I sank the series of pits which trapped unwary walkers of the night, and halfway out at pit number five, the army ants waged their wonderful warfare.

In fact it was while watching operations in another sector of this same battle-front that I 
found myself all unintentionally in the sleeping chamber of the heliconias.

Tired from a long day's work in the laboratory, I wandered slowly along the Convict Trail, aimlessly, in that wholly relaxed state which always seems to invite small adventures. It is a mental condition wholly desirable, but not to be achieved consciously. One cannot say, "Lo, I will now be relaxed, receptive." It must come subconsciously, unnoticed, induced by a certain wearied content of body or mind-and thenmany secret doors stand ajar, any one of which may be opened and passed if the gods approve. My stroll was marked at first, however, by only one quaint happening. For several weeks the jolly little trail-lizards had been carrying on most enthusiastic courtships, marked with much bowing and posing, and a terrific amount of scrambling about. The previous day-that of the first rains-numbers of lizardlets appeared, and at the same time the brown tree-lizards initiated their season of love-making. I had often watched them battle with one anothercombats wholly futile as far as any damage was concerned. But the vanquished invariably gave up to his conqueror the last thing he had swal- 


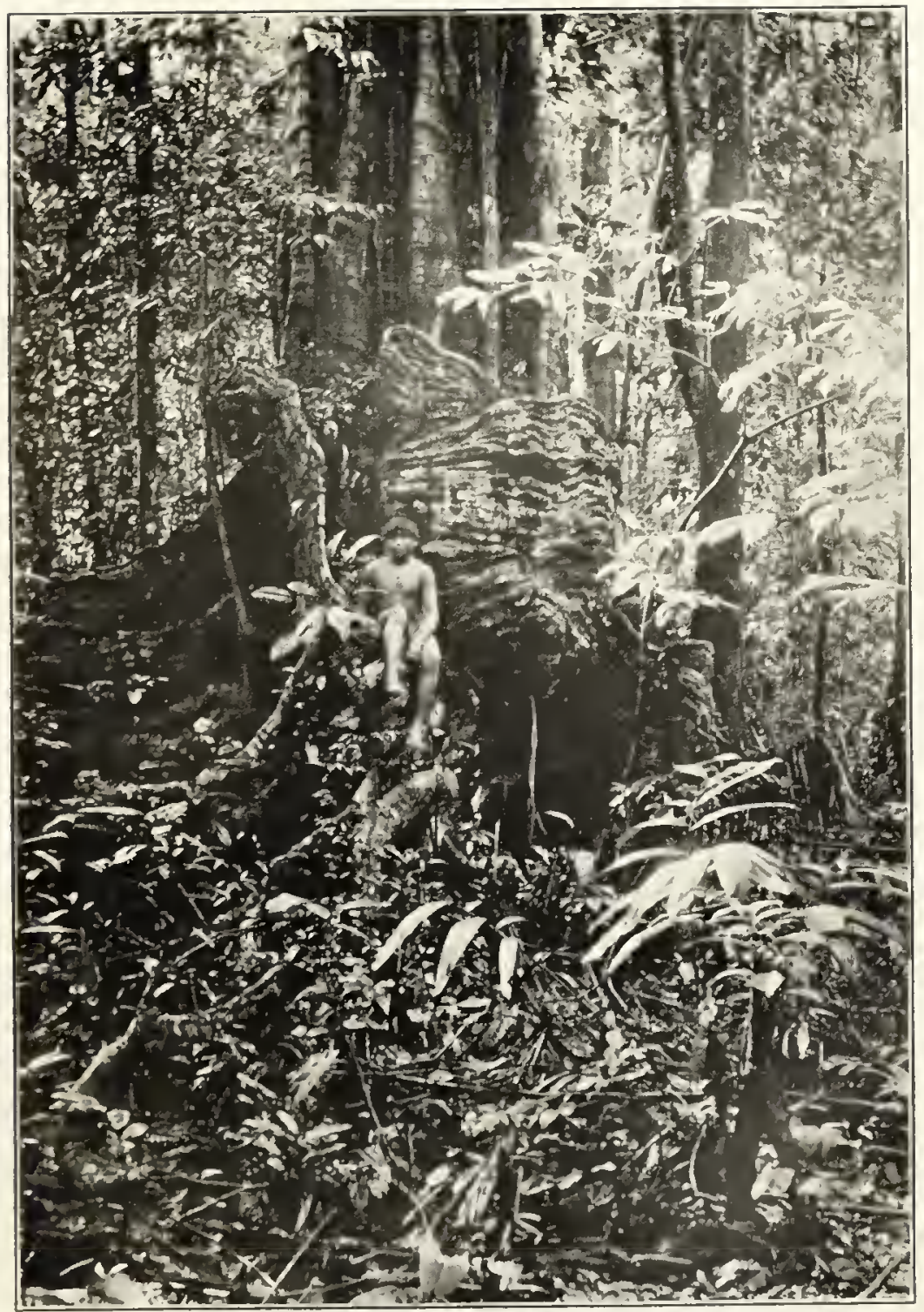

Iungle Near the Comvict T'rail 

lowed, the victor receiving it in a gluttonly rather than a gracious spirit, but allowing his captive to escape. I surprised one of thesc dark-brown chaps in the trail and seized him well up toward the head, to preserve his tail intact. Hardly had I lifted him from the ground, when he turned his head, considered me calmly with his bright little eyes, and forthwith solemnly spat out a still living ant in my direction. The inquiring look he then gave me, was exceedingly embarrassing. Who was I not to be bound in chivalry by the accredited customs of his race?

With dignity and certainty of acceptance he had surrendered, calmly and without doubt he had proffered his little substitute of sword. It was, I felt, infinitely preferable to any guttural and cowardly "kamerad!" Feeling rather shamefaced I accepted the weakly struggling ant, gently lowered the small saurian to the ground and opened my fingers. He went as he had surrendered, with steadiness and without tcrror. From the summit of a fallen $\log$ he turned and watched me walk slowly out of sight, and $I$ at least felt the bettcr for the encounter.

Of all tropical butterflies, heliconias seem the 
most casual and irresponsible. The background of the wings of many is jet-black, and on this sable canvas are splashed the boldest of yellow streaks and the most conspicuous of scarlet spots. Unquestionably protected by nauseous body fluids, they flaunt their glaring colors in measured, impudent flight, weaving their way slowly through the jungle, in the face of lizard and bird. Warningly colored they assuredly are. One cannot think of them except as flitting aimlessly on their way, usually threading the densest part of the undergrowth. No butterflies are more conspicuous or easier to capture. 'They must feed, they must pay court and mate, and they must stop long enough in their aimless wanderings to deposit their eggs on particular plants by an instinct which we have never fathomed. But these are consummations hidden from the casual observer.

Now, however, I am prepared for any unexpected meaningful trait, for I have surprised them in a habit, which presupposes memory, sociability and caution, manifested at least subconsciously.

The afternoon had worn on, and after leaving my lizard, I had squatted at the edge of a small 
glade. This glade was my private property, and the way by which one reached it from the nearby Convict Trail was a pressure trail, not a cut one. One pushed one's way through the reeds, which flew back into place and revealed nothing. Lifting my eyes from the tragedies of a hastening column of army ants, I saw that an unusual number of heliconias were flitting about the glade, both species, the Reds and the Yellows. All were fluttering slowly about and as I watched, one by one they alighted on the very tips of bare twigs, upside down with closed wings. In this position they were almost invisible, even a side view showing only the subdued under-wing pigments which blended with the pastel colors of twilight in the glade, reflected from variegated leaves and from the opening blossoms of the scarlet passion vine. Perhaps the most significant fact of this sleeping posture, was the very evident protection it afforded to butterflies which in motion during their waking hours are undoubtedly warningly colored and advertised to the world as inedible. Hanging perpendicularly beneath the twig, although they were almost in the open with little or no foliage overhead, yet they presented no surface to the 
rain of the night, and all faced northeast-the certain direction of both rain and wind.

The first one or two roosting butterflies I thought must be due to accidental association, but' I soon saw my error. I counted twelve of the Red-spots and eight Yellows on two small bushes and a few minutes' search revealed fortythree more. All were swung invariably from the tips of bare twigs, and there was very evident segregation of the two kinds, one on each side of the glade.

When I disturbed them, they flew up in a colorful flurry, flapped about for a minute or less and returned, each to its particular perch. After two or three gentle waves of the wings and a momentary shifting of feet they settled again to perfect rest. This persistent choice of position was invariably the case, as I observed in a number of butterflies which had recognizable tears in their wings. No matter how often they were disturbed they never made a mistake in the number of their cabin. A certain section of a particular twig on a definite branch was the resting place of some one heliconia, and he always claimed it.

Several were bright and fresh, newly emerged, 
but the remainder were somewhat faded and chipped at the edges. The delicate little bcings slept soundly. I waited until dusk began finally to settle down and crept gently toward a Redspot. I brought my face close and aroused no sign of life. Then I reached up and slowly detached the butterfly from its resting place. It moved its feet slightly, but soon became quiet. Then I gently replaced it, and at the touch of the twig, its feet took new hold. When I released its wings it did not fly but sank back into the same position as before. I wondered if I was the first scientist to pluck a sleepy butterfly from a jungle tree and replace it unawakened. At the time I was more impressed by the romantic beauty of it all than by its psychological significance. I wondered if heliconias ever dreamed, I compared the peacefulness of this little company with the fierce ants which even now were just disappearing from view. These were my thoughts rather than later meditations on whether this might not be a sort of atavistic social instinct, faintly reminiscent of the gregariousness of their caterpillar youth.

From any point of view I shall think better of all butterflies for this discovery; thcir desire 
for company, the instinctive wisdom of place and posture, the gentleness and silence of the little foregathering in the jungle. As I walked back along the trail several late comers passed me, vibrating softly through the twilight, headed for their glade of dreams.

Subsequent visits to this glade emphasized the strength of association of this little fraternity, by realization of its temporal brevity. Three weeks after I first discovered the glade, I returned in late afternoon and waited silently. For a time I feared that the mariposal friendship was a thing of the past. But a few minutes before five the first Red-spot fluttered by, in and out among the twigs and leaves, as one slips an aeroplane through openings in drifting clouds. One by one, from all directions, the rest followed, until I counted twelve, twenty, thirtyfour. Many of the twigs were now vacant, and most of the heliconias were tattered and forlorn, just able to keep at their fluttering level. There was something infinitely pathetic in this little company, which in less than a month had become so out at elbow, so aged, with death close ahead, yet with all their remaining strength making their way from north and from south, 
from dense and from open jungle, to keep tryst for this silent, somnolent communion. I rose quietly and passed carefully from the glade, disturbing none of the paper-thin silhouettes, so like the foliage in outward seeming, yet so individual, each perhaps with dim dreams of flowers and little meetings and wind tossings; certainly with small adventures awaiting their awakening on the morrow, and a very certain kismet such a short way ahead.

Two weeks after this, only three butterflies came to the glade, one newly painted, freshly emerged, the other two old and tattered and very weary.

I loitered on my homeward way and before I reached Kalacoon found myself in the Convict Trail in full moonlight. At one turn of the path a peculiar tinkling reached my ear. It was a veritable silver wire of sound-so high, so tenuous that one had to think as well as listen to keep it in audible focus. I pushed through a growth of cecropias and at once lost the sound never to hear it again, but in its place there appeared a very wonderful thing-a goodsized tree standing alone and exposed, bathed in full moonlight, and yet gleaming, as brightly 
as if silhouetted against complete darkness, by the greenish light of numberless fireflies. After the first marvel of the sudden sight, I approached and pulled down a branch and counted twenty-six glowing insects, as close together as the blossoms on a Japanese cherry branch. There were hundreds upon hundreds, all clustered together in candelabred glory, hidden from the view of all, at the farther side of this dense thicket. As I left I remembered with gratitude the silver wire of sound which had guided me, and in a far corner of my mind I stored a new memory-one which I could draw upon at need in distant times of pain, or of intolerance or perhaps in some lull of battle-the thought of a tree all aglow with living flames, in the moonlight of the Convict Trail. 
WITH ARMY ANTS "SOMEWHERE" IN THE JUNGLE

PIT number five had become a shambles. Number five was one of the series of holes dug along the Convict Trail to entrap unwary walkers of the night-walkers or hoppers, for frogs and toads of strange tropical sorts were the most frequent victims. It was dug wide and deep on the slope of an ancient dune of pure white sand, a dune deep hidden in the Guiana jungle, which had not heard the rush and slither of breaking waves for centuries untold. All around this quiet glade was an almost pure culture of young cecropia trees. Day after day the pit had entrapped big beetles, rarely a mouse of some unknown species, more frequently a frog.

Now I stood on the brim, shocked at an unexpected sight. A horde of those Huns of the jungle, army ants, had made their drive directly 
across the glade, and scores of fleeing insects and other creatures had fallen headlong into this deep pit. From my man's height it was a dreadful encounter, but squatting near the edge it became even more terrible; and when I flattened myself on the sand and began to distinguish individuals and perceive the details from an ant's point of view, I realized the full horror and irresistibility of an assault by these ants.

One is not strongly affected by the dying struggles of a single grasshopper captured by a cuckoo or flycatcher. An individual roach being torn to pieces moves one but slightly. A batrachian, however, has more claim on our emotions, and my sympathy went out to a small, sandy-white frog who was making a brave fight for his life. The pit was alive with a host of the army ants, and wherever the little frog hopped, some soldier or heavy-jawed worker soon found him and sank jaws into his soft skin. With frantic scratching the frog would brush it off and leap again, only to be again attacked. The most horrible thing about these ants is their leaping ability. The hop of a bird or the jump of a toad when going about their usual business of life, if we think of it at all, is 
only amusing. But the sudden leap of a bulldog or tarantuli, and the corresponding vicious attack of these ants, is particularly appalling. I saw a soldier leap a full inch and a half toward the landing thud of the frog and bite and sting at the instant of contact. I did not dare go into the pit. No warm-blooded creature could have stood the torture for more than a few seconds. So I opened my umbrella and reaching down, scooped up the sand-colored frog. A half-dozen ants came up in the same instrument, but $\mathbf{I}$ evaded them and tied up the tormented batrachian in my handkerchief.

My next glance into the pit showed a large toad, squatted on a small shelf of sand, close to the edge of a crowded column of ants. $\mathrm{He}$ was a rough old chap, covered with warts and corrugations, and pigmented in dark gray, with mottlings of chocolate and dull red and occasional glints of gold. He was crouched flat, with all his fingers and toes tucked in beneath him. His head was drawn in, his eyes closed, and all his exposed surface was sticky with his acid perspiration-the sweat of fear. He knew his danger-of that there was no doubt-and he was apparently aware of the fact that he could 
not escape. Resignedly he had settled on the very line of traffic of the deadly foe, after intrenching himself and summoning to his aid all the defenses with which nature had endowed him. And he was winning out-the first vertebrate I have ever known to withstand the army ants. For a few minutes he would be ignored and his sides would vibrate as he breathed with feverish rapidity. Then two or three ants would run toward him, play upon him with their antennæ, and examine him suspiciously. During this time he was immovable. Even when a soldier sank his mandibles deep into the roughened skin and wrenched viciously, the toad never moved. He might have been a parti-colored pebble embedded in its matrix of sand. Once, when three bit him simultaneously, he winced, and the whitish, acrid juice oozed from his pores. Usually the ants were content with merely examining him. I left him when I saw that he was in no immediate danger.

One other creature was quiescent in the pit and yet lived: a big, brown, hardbacked millipede. Like the frog, he fully realized his danger and had sunk his bulk partly into the sand, bending down head and tail and presenting only 
mailed segments. A mob of ants were trying vainly to bite their way into this organie citadel.

For the dozens of grasshoppers, crickets, roaches, beetles, spiders, ants, and harvest men, there was no escape. One daddy-long-legs did a pitiful dance of death. Supported on his eight long legs, he stood high out of reach of his assailants. He was balanced so exactly that the instant a feeling antenna touched a leg, he would lift it out of reach. Even when two or three were simultaneously threatened, he raised them, and at one time stood perfectly balanced on four legs, the other four waving in air. But his kismet came with a concerted rush of half a dozen ants, which overbore him, and in a fraction of time his body, with two long legs trailing behind, was straddled by a small worker and borne rapidly away.

I now flattened myself on an antless area at the edge of the pit and studied the field of battle. In another half-hour the massacre was almost over. Five double, and often quadruple, columns were formed up the sandy cliffs, and the terrific labor of earrying out the dead victims began. The pit was five feet deep, with 
perfectly straight sides, which at the rim had been gutted by the rain, so that they actually overhung. Yet the ants which had half-climbed, half-tumbled and rolled their way to the bottom in the wake of their victims, now set themselves to solving the problem of surmounting these cliffs of loose, crumbling grains, dragging loads which, in most cases, were much heavier than themselves. Imagine a gang of men set to carrying bundles of one to two hundred pounds up perpendicular cliffs twelve hundred feet in height, and the task of the army ants is made more vivid. So swiftly did they work and so constantly shifted their formations and methods of meeting and surmounting difficulties, that I felt as I used when looking at a three-ring circus. I could perceive and record only a small part of the ingenious devices and the mutual assistance and sharing of the complicated conditions which arose at every step.

Among the frightened victims, even for those endowed with excellent eyesight and powerful flight, there was only hopeless confusion and blind terror. Instead of directing their flight upward, they drove from side to side. Those whose leaps should have carried them out, sim- 
ply kicked out blindly and brought up against the sandy walls.

If leaf-cutting ants had been at work here, there would have been a certain amount of cooperation. Certain ones would have cut leaves, other individuals would have picked them up and transported them. But with the army ants this mutual assistance was sublimated, developed to a quintessence of excellence. If $I$, seated on the rim, overlooking the whole, had been an all-powerful spirit, gifted with the ability to guide by thought simultaneously all the ants within sight, such guidance could not have bettered the cunning coöperation, the unexpectedly clever anticipation of trouble, the marvelous singleness of purpose and manifold effectiveness exhibited by these astounding creatures.

First, as to the personnel of the army ants. Roughly I divided them into two categories, white-heads and black-heads. The latter were by far the more numerous and, as a rule, were smaller, with less powerful jaws. But this did not mean that the white-heads were all soldiers. Most of them indeed were the hardest workers. Between the great extremes of size in each of these two types, there seemed to exist only a 
difference of degree. The smallest black-head laborers, only a little more than one-fifth of an inch long, did their bit, flew like bull pups at any prey which showed signs of life, and staggered bravely along with any piece of loot which their short legs could straddle.

The white-heads, twice as large, were the strong men of the community, putting all their activity into the labor, shouldering, pushing, dragging, lifting, singly or in unison. These persons had powerful jaws, but jaws which were stout and scissor-edged. The largest of the white-heads were armed with reaping-hooks, long inwardly-pronged jaws, curved like the tushes of ancient mammoths, too specialized for carrying loads, but well adapted for defense of the most powerful character. Yet, as we shall see, even these were not too proud to work, when occasion demanded it. But their jaws were so enormous that they had to carry themselves very erect, and they could not make quite as good time as the other castes.

All had reddish brown abdomens, with darker thoraxes and white or black heads. These heads bulged on each side like the domes of observatories. Exactly in the center of each dome, 
looking like the jet-black head of a tiny pin, was the single remaining facet of the eye, the degenerate residue of the hundreds which were present in their ancestors, and which the perfect males and females still possess and look through. Even this single eye is a sham, for its optic nerve dies out before the brain ganglion is reached; so we come to the astounding realization that these ants are totally blind, and carry on all their activities through the sense or senses residing in those marvelous quivering antennæ. Here are beings spending all their lives in ceaseless changing activities, meeting and coping with constantly new conditions, yet wholly blind. Their sense of smell dominates their judgment of substance, and the moment an army ant reached my moccasin he sank jaws and sting deep into the fabric as instinctively and instantly as when he executed the same manœuvers more effectively on my hand.

Keeping this handicap in mind, the achievements of these little creatures assumed a still greater significance, and with renewed interest and appreciation I again surveyed the scene in the amphitleater before me. When the majority of the pit victims had been slain, the process 
of carrying them up to the surface began. The hordes of ravening ants resolved themselves, as I have said, into five distinct columns of traffic which, inch by inch, fought for a footing up three of the four sides.

Half of the bottom of the pit was a sort of flat table-land several inches higher than the rest, and the first thing the ants did was to carry all their booty to this steppe, in pieces or bodily, some of the unfortunate creatures still protesting weakly as they were dragged along. In fifteen minutes the lowest part of the pit bottom was deserted, and after much hesitation I vaulted down and found a footing reasonably. safe from attack.

Two traffic columns had already reached the summit, and the others were forging rapidly ahead. All used a similar method of advance. A group of mixed castes led the way, acting as scouts, sappers, and miners. They searched out every slope, every helpful step or shelf of sand. They took advantage of every hurdle of white grass-roots as a welcome grip which would bind the shifting sand grains. Now and then they had to cross a bare, barren slope with no natural advantages. Behind them pressed a 
motley throng, some still obsessed with the sapper instinct, widening the trail, tumbling down loose, dangerous grains. Some bore the firstfruits of victory, small ants and roaches which had been the first to succumb. These were carried by one, or at most by two ants, usually with the prey held in the jaws close beneath the body, the legs or hinderpart trailing behind. In this straddling fashion the burden was borne rapidly along, an opposite method from the overhead waving banners of the leafcutters.

With these came a crowd of workers, both white and black-headed, and soldiers, all emptyjawed, active, but taking no part in the actual preparation of the trail. This second cohort or brigade had, it seemed to me, the most remarkable functions of any of the ants which I saw during my whole period of observation. They were the living implements of trail-making, and their ultimate functions and distribution were so astounding, so correlated, so synchronized with the activities of all the others that it was difficult not to postulate an all-pervading intelligence, to think of these hundreds and thousands of organisms as other than corpuscles in a dy- 
namic stream of life controlled by some single, outside mind.

Here, then, were scores of ants scrambling up the steep uneven sides, over ground which they had never explored, with unknown obstacles confronting them at every step. To the eye they were ants of assorted sizes, but as they advanced, numbers fell out here and there and remained behind. This mob consisted of potential corduroy, rope-bridges, props, hand-rails, lattices, screens, fillers, stiles, ladders, and other unnamable adjuncts to the successful scaling of these apparently impregnable cliffs. If a stratum of hard sand appeared, on which no impression could be made, a line of ants strung themselves out, each elaborately fixing himself fast by means of jaws and feet. From that moment his feverish activity left him: he became a fixture, a single unit of a swaying bridge over a chasm; a beam, an organic plank, over which his fellows tramped by hundreds, some empty, some heavily laden. If a sudden ascent had to be made, one ant joined himself to others to form a hanging ladder, up which the columns climbed, partly braced against the sandy wall. At uncertain, unguarded turns a huge soldier 


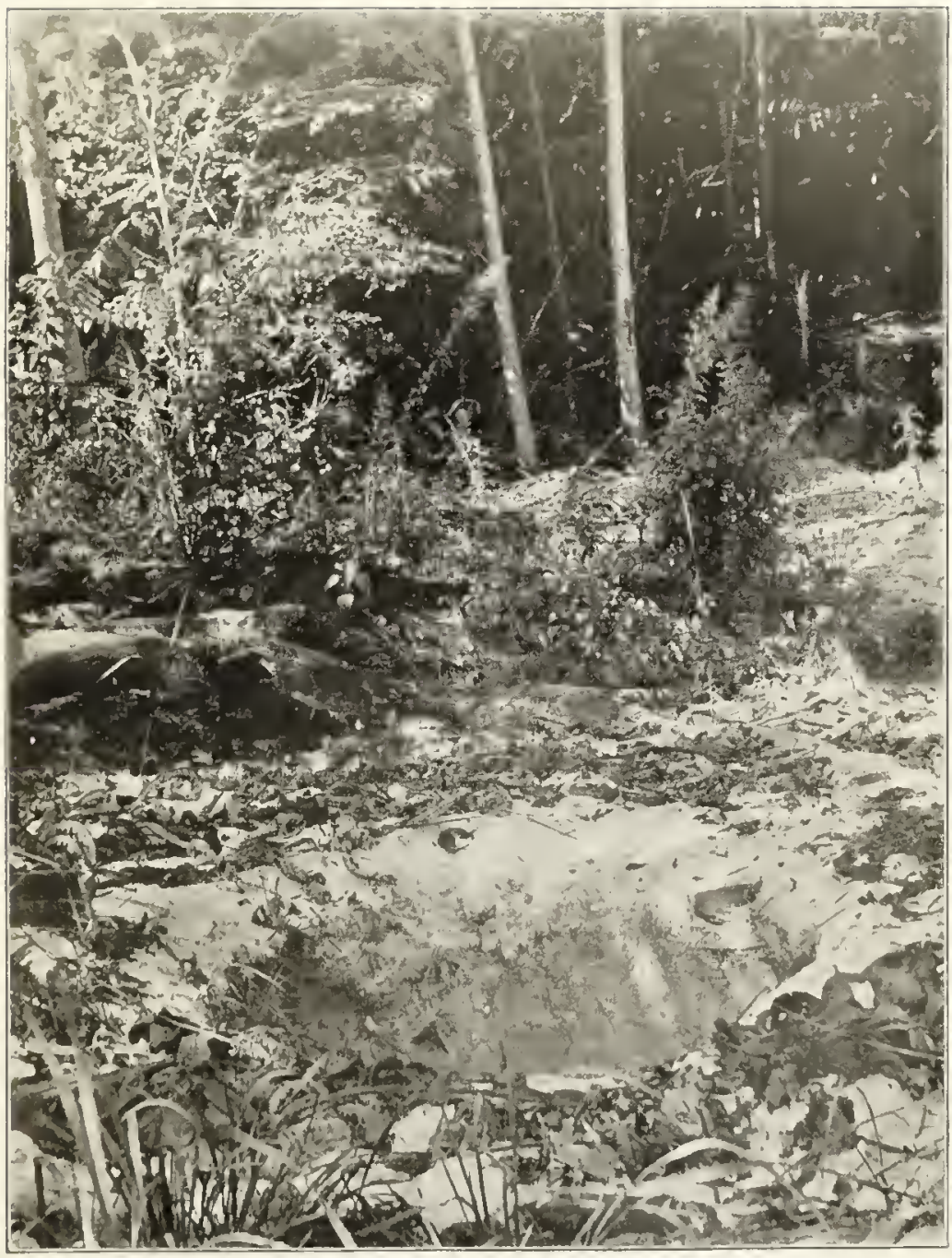

Iit Number Five 

would take up his station, with as many functions and duties as a member of the Broadway traffic squad. Stray, wandering ants would be set right by a single twiddle of antennæ; an over-burdened brother would be given a helping jaw and assisted for some distance to the end of his beat. I was especially interested in seeing, again and again, this willingness to help bear the burdens. It showed the remains of an instinct, inhibited by over-development, by ultraspecialization of fighting paraplernalia, still active when opportunity gave it play. At the first hint, by sound or smell, of danger, the big soldier whirled outward and, rearing high on his legs, brandished his mighty blades in mid-air. Here was an ideal pacifist, who could turn his sword into a plowshare at will, and yet keep the former unsheathed for instant use.

When I watched more closely, I detected more delicate gradations of mutual aid. At the same level in two columns of ascent, the same stratum of hard sand was encountered. To one column the sand presented a rough surface which gave good foothold. Here the single line of ants which was ranged along the lower edge of the trail, in lieu of hand-rail, all faced down- 
ward, so that the ants passing above them walked partly on the abdomens and partly on the hind legs of their fellows. In the second column, the surface of the sand was smooth, and here the burdened ants found great difficulty in obtaining a foothold. In this instance the supporting gang of ants faced upward, keeping their place solely by their six sturdy legs. This left head and jaws free, and in almost every case they helped the passage of the booty by a system of passing from jaw to jaw, like a line of people handing buckets at a fire. The rightful carriers gave up their loads temporarily and devoted their attention to their own precarious footing.

I learned as much from the failures of this particular formation as from its successes. Once a great segment of a wood-roach was too much for the gallant line clinging to the sides of the pit, and the whole load bro'ze loose and rolled to the bottom. Of the hand-rail squad only two ants remained. Yet in four minutes another line was formed of fresh ants, - ants who had never been to the spot before,-and again the traffic was uninterrupted. I saw one ant deliberately drop his burden, letting it bounce and 
roll far down to the bottom of the pit, and instantly take his place in the line of living guardrails. The former constituents of the line had clung to the roach segment through all its wild descent, and until it came to rest at the bottom. Without a moment's pause, they all attacked it as if they thought it had come to life, then seized it and began tugging it upward. In a fraction of time, without signal or suggestion or order, the hand-rails had become porters. The huge piece of provender had rolled close to an ascending column on the opposite side of the pit, and up this new trail the bearers started, pulling and pushing in unison, as if they had been droghers and nothing else throughout the whole of their ant-existence.

One climax of mutual assistance occurred near the rim of the pit on a level with my eyes, where one column passed over a surface which had been undermined by heavy rain, and which actually overhung. I watched the overcoming of this obstacle. All the ants which attempted to make their way up at this point lost their footing and rolled headlong to the bottom. By superformicine exertions a single small worker at last won a path to the rim at the top. Around 
the edge of the pit innumerable ants were constantly running, trying, on their part, to find a way down. The single ant communicated at once with all which came past, and without hesitation a mass of the insects formed at this spot and began to work downward. This could be done only by clinging one to the other; but more and more clambered down this living ladder, until it swayed far out over the vastness of the pit, three inches in length. I had never lost sight of the small worker, who had turned on his tracks and was now near the bottom of the ladder, reaching wildly out for some support-ant, grass, or sand. I was astonished to see that, as the length and consequent weight of the dangling chain increased, the base support was correspondingly strengthened. Ant after ant settled itself firmly on the sand at the top, until a mat of insects had been formed, spread out like animate guy-ropes.

At last the ultimate ant in the rope touched the upraised jaws of the soldier far below. The contact acted like an electric shock. The farthest ant in the guy-rope gang quivered with emotion, a crowd of ants climbed down and another up, and bits of insect and spider prey 
began to appear from the depths of the pit, over the living carpet suspended from the brim. For an inch the droghers climbed over the bodies braced against the cliff. Then, where the surface became smooth, the dangling chain came into use. Before the rim of the pit was reached, the chain had become a veritable hollow tube of ants, all with heads inward, and through this organic shaft passed the host from the ascending column. But it was far more than any mechanically built tube. When an extra large piece of loot came up, the tube voluntarily enlarged, the swelling passing along until the booty and its bearers emerged at the top.

Within five minutes after this last column was completed, there passed over it, out of the pit, a daddy-long-legs with legs trailing, perhaps the same one which I had seen in the tragic little dance of death. There followed two silvery-gray ants, a wood-roach in two installments, part of a small frog, three roaches, and two beetles. These latter gave a great deal of trouble and tumbled down the cliff again and again.

When all the columns were established and the provision trains in full movement, I leaped 
out and scouted round for the rest of the army. I found that the pit was only an incident. In all directions lines of ants poured past, carrying booty of all sizes and descriptions. Here and there the huge soldiers walked slowly along the outskirts, directing stragglers, looking for danger, snapping at any roach or strange ant which rushed frantically by, and holding it until it was carried off by nearby workers.

I followed a column over logs and leaves to where it ascended a cecropia tree. A harvest of small arboreal insects was being gleaned high overhead. As I watched, there came a heavy downpour of rain, a typical shower of the tropics, with a scattering of heavy drops out of the full sunshine and then a sudden clouding and a straight deluge for a few minutes. The reaction of the ants was interesting. They did not like the water, and it was comical to see them tumble over one another to get under shelter. Like the doorways of city shops in a shower, every curled-up leaf was packed, and from every crevice of bark projected sundry abdomens and hind legs for which there was no room inside. When the bearer of a large bag of booty found a convenient corner, he backed 
into it and left his meat sticking out in the rain.

After the shower all came forth at full speed, but for some minutes there was considerable confusion. The sluice of water had evidently washed away much of the scent which stood for guideposts, directing signs, and pointing hands along the trail. Only after many false starts were the old pathways discovered and again traversed. In one place the ants climbed a huge log and marched along the top for six or seven yards. I timed them carefully and found that on this straight-away track their average speed was two and a half feet in ten seconds. So they covered a mile in three hours and a half, and in all the army ants I have ever watched this rate of speed never slackens; in fact, it frequently greatly increases. When hot on the scent of prey they double their usual gait.

There are as many ludicrous sights to be seen in the ranks of army ants as there are among the banner-decked processions of the leaf-cutters. Along the tree-trunk track came three big whiteheads straddling an inch-worm-in this case an inch-and-a-half-worm. They leaned forward and downward, the heads of those behind over- 
lapping the abdomens in front, and they looked for all the world like the riders of an oldfashioned three-seated bicycle, spurting along the trail. Another simile, even more vivid, evoked the vision of some weirdly constructed, elongated myriopod with eighteen legs. After a hard fight, in the course of which I was stung twice, I unseated the trio and took the measuring worm away from them. As I lifted it from where it had fallen, at least fifty ants hurled themselves at the spot, jaws snapping, trembling with violent rage. I walked ten feet away and dropped the worm in the midst of another column, and within an equal number of seconds three new white-heads had mounted it and were hustling it along-the replicas in appearance and method of the first team.

Many species of stranger ants were killed and carried off as food, but now and then I noted a most significant exception. In three different parts of the glade I saw good-sized, pale, fleshcolored ants which walked unharmed in the very ranks of the terrible host. Unharmed they were, but not wholly above suspicion, and their progress was not an easy one. For every unburdened ant which passed leaped at the pale one, anten- 
naed it fiercely for a moment and reluctantly released it. One could read their indecision as they slowly loosened their hold, turning again and again and waving their antennæ as if to make sure that it was not better to act on their suspicion and slay at once. Finally, they always passed on. The pale ones had some strange inaudible password, some sensory parole which protected them. And their total lack of fear showed their knowledge of their immunity. Even with the added sense of sight which they possessed, they chose voluntarily to accept this dubious, reluctantly accorded friendship. But it was probable that, even if they lived in the very community or nest of the army ants, theirs was the hard-earned dependence of neutrals who were liable to be knocked down at a moment's notice, and searched for any strange, inimical scent which would spell instant death.

In one place the army column made a slight détour round a hillock of sandgrains upon which a host of tiny brown ants was laboring. I thought it remarkable that such immunity should be accorded these dwarfs, and I sought the reason. It was forthcoming at once when $I$ 
gingerly lifted a big soldier with the forceps and dropped him on the ant-hill. What occurred was a replica of the usual army ant scene, but enacted as if viewed through the large end of an opera-glass. Scores of the minute brown chaps rushed forth and for a moment fairly overbore the white-headed giant. Indeed, before he could recover he was dragred partly down a sandy hole. His jaws brandished and champed, but his assailants were so small that they slipped through them unharmed. Many actually seized the jaws themselves and were hurled through the air as they snapped together. Regaining his feet, the great army ant staggered off and, fortunately for him, rolled down a slope into another column of his own kind. Here he freed himself little by little, scraping off the minute fighting browns with the help of two very small workers, whose jaws, being much less in size, were better able to grip the diminutive furies. Their assistance was half-hearted, and the odor of the dead and dying pygmies was distinctly disliked by them. They were apparently well aware of the capabilities of these small cousins, and held them in high respect.

This outburst of successful defense on the 
part of the small ants was unexpected. I glanced back at their hill and saw them unconcernedly piling up grains as if nothing had occurred to disturb them. I wondered if, with senses perfectly attuned, with an enlargingglass ability of observation, one might not find still lesser communities which would in their turn consider the little brown ants as giants, and on the space of a pin's head attack them and fly at their throats.

A species of silvery-gray ant which was abundant in the glade was an object of special enmity, and even after one of these was killed and being carried along, passing army ants would rush up and give it a vicious, unnecessary nip. One such ant made its escape from the hold of a small worker; but before it had taken ten steps it was actually buried under a rolling mass of army ants. The flying leap with which these athletes make their tackle would delight the heart of any football coach, although their succeeding activities belong rather to savage warfare. Termites, or so-called white ants, are, curiously enough, immune from attack. Yet these slow-moving, fat-bodied creatures would seem first-rate food, and the fight which they 
could put up would not stand an instant before a concerted rush of battling army ants. The saving character is doubtless odor or taste. I dropped a tunnelful of these insects in the path of the army ants and they were quite ignored, although the black-and-white-headed fellows were terribly angry and excited.

I coveted a small beetle of peculiar pattern which the ants were hurrying along, and in taking it from them I accidentally cut an army ant in two. His abdomen rolled down a small slope and caused considerable panic among his fellows. They formed a ring round it and waved their antennæ in mid-air, the scent of the blood of their own kind causing them to forget hurry and burdens and their normal activities. The front part of the ant seemed but little inconvenienced and endeavored to seize and carry the load it had dropped. Little by little it began to realize that all was not right, and after one or two attempts to turn and investigate, it ran rapidly down the trail. I made a dab at it to put it out of what seems better called inconvenience than misery, but succeeded only in bisecting the . thorax, so that there remained the head and front pair of legs. These lost nothing in activ- 
ity, and by means of the single pair of legs the head rowed itself rapidly along, its antennæ twiddling vigorously those of every ant it met. This was uncanny, a little too much, and I ground the fraction of ant to powder. No wonder the army ant is such a virile creature, endowed with the most extreme emotions, when, with such a small section of its anatomy remaining it can continue to show such astounding activity.

One could study for hours the interactions among the army ants themselves. More than once I saw a good-sized ant transporting one of its fellows, exactly as it would carry a bit of booty. I tried to examine this ant, and to my surprise, both attacked me ferociously. The one which was carried was neither dead, ill, nor disabled, but very much alive. I cannot even suggest an explanation of this phenomenon, as it did not seem an attempt to aid a comrade in distress.

As dusk began to settle down, I found a column of ants which must have discovered and sacked the city of some stranger ants. They were laden with ant-booty: eggs, larvæ, and dead ants by the hundred. It was comprehensible, but what I did not at first understand was 
a dense line of ants moving solidly in one direction, all laden with large eggs and immatureants, which they were carrying with great care. A large number of the huge soldiers patrolled the outer flanks of the column, more than I had seen with all the other traffic lines together. I realized at last that $I$ was looking at an actual moving of a portion of the army ant houschold itself. It was guarded and transported with all the care of which these insects were capable. The infant ants rested safely in the great jaws, the same jaws which all day had been busy slashing and biting and tearing, and carrying food for these same infants.

And now the tropical night began to close down and I made my way back to the sandpit. The last of the columns was making its way out, systematically from the bottom up, each ant following in turn. The moment the last bit of prey passed up the column, by some wonderfully delicate and subtile sense, every ant knew of it, and the corduroy rose, the handrails unjointed themselves, the ropes unspliced, the embankments dislodged of their own volition, . and stepping-stones took to themselves legs. After hours of total inactivity, these sentient 
paraphernalia of the via formica became, once more, beings surcharged with ceaseless movement, alert and ready to become a useful cog in the next movement of this myriad-minded machine. I jumped down into the pit. The great gold-spotted toad stretched and scratched himself, looked at me, and trembled his throat. I was not an army ant! The millipede cautiously reared its head from the sand and felt timidly about.

I looked out and saw the last of the mighty army disappearing into the undergrowth. I listened and heard no chirp of cricket, nor voice of any insect in the glade. Silence brooded, significant of wholesale death. Only at my feet two ants still moved, a small worker and a great white-headed soldier. Both had been badly disabled in the struggles in the pit, and now vainly sought to surmount even the first step of the lofty cliff. They had been ruthlessly deserted. The rearing of new hosts was too easy a matter for naturc to have evolved anything like stretchers or a Red Cross service among these social beings. The impotence of these two, struggling in the dusk, only emphasized the terrible vitality of thcir distant fellows. As the last twilight 
of day dimmed, I saw the twain still bravely striving, and now the toad was watching them intently. A poor-me-one called mournfully from a distance, and I walked slowly toward home. 


\section{$\mathrm{X}$}

\section{A YARD OF JUNGLE}

Withrn five minutes the daily downpour of tropical rain would drench the jungle. At this moment the air was tense with electricity, absolutely motionless, and saturated with odorous moisture. The voices of all the wild creatures were hushed. The sense of mystery which is always so dominant in a tropical jungle seemed nearer, more vital, but more than ever a mystery. Its insistency made one oblivious of the great heat. The beating of one's heart became a perceptible sound, absurdly loud. All the swamp and jungle seemed listening to it.

Suddenly a voice came out of the heart of this mystery, and fittingly enough, the voice seemed something a little more or less than human, and also fittingly it uttered but a single word, and that word a question. And the listener realized that the answer to the question was the only thing which made life and work worth 
while. The throb of the blood in his veins was forgotten, and all his senses reached out to the sights and sounds and scents about him. And again the great black frog called from its slimy seat hidden in the still blacker water of the jungle swamp. Its voice was deep, guttural, and a little inhuman, but it asked as plainly as any honest man could ask, Wh-y? And after a minute, $W h-y$ ?

I squatted in the center of a trail. Within walking distance behind me flowed the yellow waters of the Amazon, and the igarapé from which the frog had called was even now feeling the tidal heave of the ocean. Ahead, the jungle stretched without a break for three thousand miles or more. And here for a week I had suffered bodily torture, twisting into unhappy positions for hours at a time, watching the birds which crowded the berry-laden foliage of a single jungle tree. In the cool of early morning, throughout the terrible breathless heat of midday and the drenching downpour of afternoon, the frog and I put our questions. There was hope in our interrogation. And my five senses all gave aid, and my hand wrote down facts, and my mind pondered them. 
In the very suburbs of Pará, at the mouth of the great Amazon and within a hundred miles of the equator, I found a Mecca of bird-life. It was a gastronomic Mecca to be sure, a tall, slender, wild cinnamon tree,-canella do matto the natives called it. For a full week I invited torture by attempting to study the bird-life of this single tree. This thing had not been done before; it might not be worth the doing. But testing such possibilities are as important to a naturalist's work as following along the more conventional and consequently more certain lines of investigation. I had no time for exploration of the surrounding country; so I had determined to risk all my precious hours upon intensive observation in one spot.

The century before, a plantling had pushed up through the jungle mold and had won success in the terrible competition of the tropicsthe helpless, motionless, silent strife of the vegetable folk. Year by year the lichen-sculptured trunk had pushed its way upward toward light and air, miraculously saved from the deadly embraces of the lianas which crawled forever through the jungle. Today it had gained an accepted place. Although no forest giant, with 
no great buttresses or masses of parasitic growths, it held up its branches and twigs in full sunlight a hundred feet or more above the ground. And its twiggy fingers were laden with a wonderful harvest of fruit, uncounted berries which attracted the birds from distant roosts and drinking places.

Here, then, a thousand combinations of fate had led me, and here I suffered day by day. Bound to the earth like other normal men, my eyes should have been directed forward. Now I forced them upward for hours at a time, and all the muscles of neck and shoulders revolted. Then eyestrain and headache and a touch of fever followed, and I cast about for means to ameliorate my bodily ills. I dragged a canvas steamer chair to my place of vigil and all my body was grateful.

In memory, there now remain only the high lights of new discoveries, the colorful moments of unalloyed realization of success. Nevertheless this new method of tropical work brought its own new delights and trials. One joy lay in the very difficulties to be overcome. Every sense came into play. Sight, first and foremost, had been put to the most severe of tests in at- 


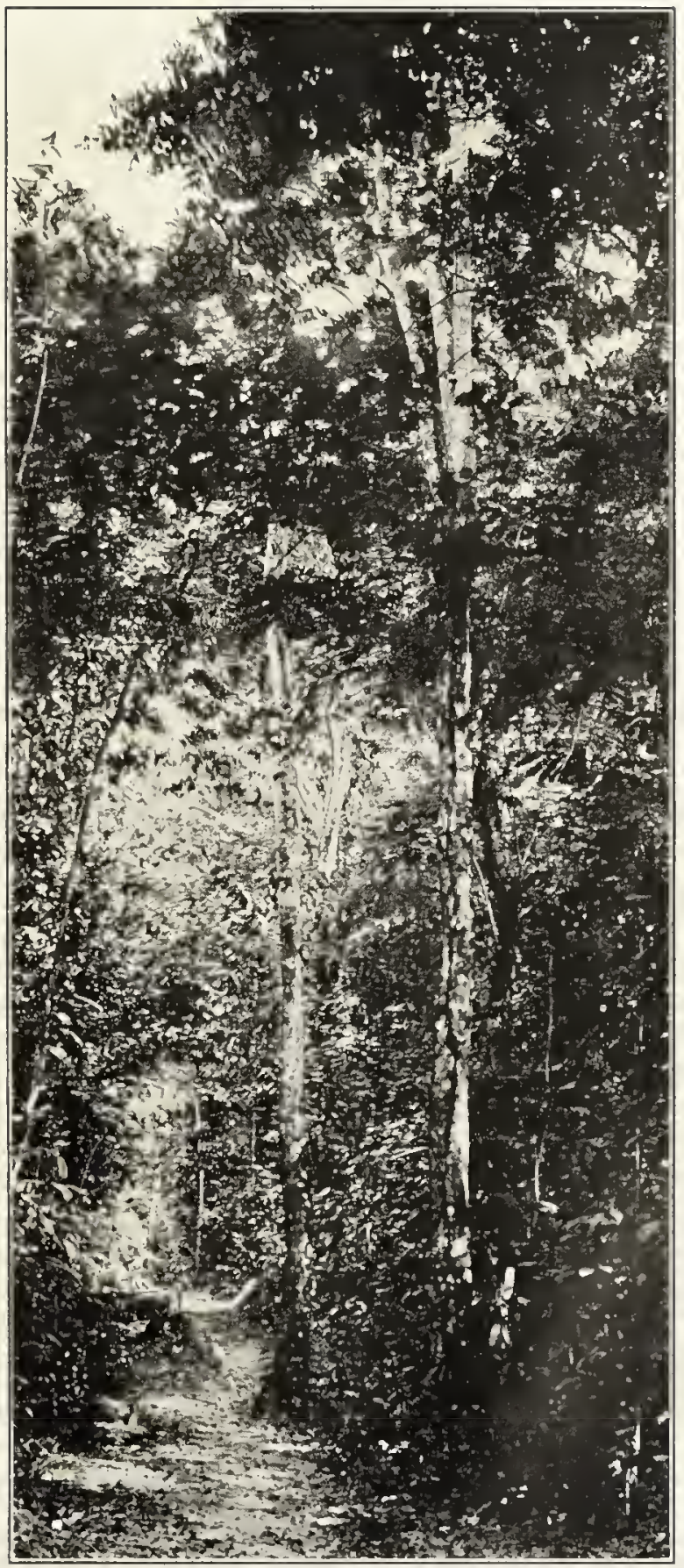

Canello do Matto- the Tree of the Birds 

tempting to record the happenings against the glare of the sky high up among the foliage of this bit of jungle. I strained through my highpower glasses, until, when I looked without them, the world seemed withdrawn, dwarfed, as in the horrid imaginings of fever. The glasses gained in weight as I held them pointing vertically until they fairly dropped from my aching arms. My ears strove to catch every song, every note which might prove a character of worth. The jungle scents played upon my emotions and sometimes dominated my work; the faint aroma from some invisible orchid overhead, the telltale musk from a passing mammal, the healthful scent of clean jungle mold. As for taste, I had tested the aromatic berries and fruit of my canella tree, and for science' sake had proved two warningly colored insects. My sense of feeling had operated involuntarily and wholly aside from my scientific desires. Whether stimulated by dozens of mosquitoes, scores of ants, or hundreds of bêtes rouges or "mucuims," the insistency of discomfort never discouraged a primary desire to delve as deeply as possible into the secrets of this small area of tropical jungle. 
As I walked slowly about beneath the tree or lay back resting in the chair, I seemed to be watching creatures of another world. Whether I ogled them with glasses or now and then brought one down with a charge of small shot, I was a thing of no account to the berry-eating flocks high overhead. A vulture soaring lower than usual passed over the tree, and the shadow of his partial eclipse of the sun froze every bird to instant silence and complete immobility. But my terrestrial activities wrought no excitement. The shot whistled through the foliage, one of their number dropped from sight, and life for the rest went on without a tremor. To ancestral generations, danger had come always from above, not below.

The very difficulty of observation rendered this mode of research full of excitement, and at the same time made my method of work very simple. Against the sky, green, blue, or black feathers all appear black, and the first two days my glasses helped but little. For several minutes I would watch some tiny bird which might have been a yellow warbler had I been three thousand miles farther north. After memorizing personal characters, scrutinizing its flight 


\section{A YARD OF JUNGLE}

and method of feeding, striving to fix its individuality, I would secure the bird, and find in all probability that it was a calliste, or tanager of brilliant plumage. 'Tomorrow, if I were lucky, I might be able to tell off the numbers of this species, to watch them and to know that I was watching them. But recognition would not be by way of the cerulean or topaz or amethystine hues of plumage, but by the slight idiosyncrasies of flirting tail or wing or of general carriage.

Day by day, as I came to know better the jungle about me, I began to perceive a phase which did not change. Even when the sun shone most brightly, when the coolness of early morning had not yet passed, the mood of the Amazon jungle remained. It was consistent, this low swampy jungle, in its uniform, somber mystery. In spite of wholesale exaggeration it was the dangers which came to mind. Of all places in the world this was probably fullest of life, both in numbers and diversity. Yet it was death-or the danger of death-which seemed in waiting, always just concealed from view.

Beneath my tree I squatted silently. Just overhead the foliage might have been almost 
northern. The finely cut leaves were like willow, and at one side an oak, unusual but still an oak, reached out a thousand thousand motionless leaves, breaking the glare into innumerable patches. But ahead, the terrible interlacing of vines and thorny ropes, the strangle-hold of serpentine lianas on every available trunk-all this could be only tropic.

The ground glistened here and there with a film of black water which revealed the swamp. Everywhere the mold and leaves of a hundred years lay scattered, the last fallen still green. Many feet above, great fans dangled, rayed fronds dry and crackling, fallen from high overhead, and suspended, waiting for the interfering twigs and foliage to die in turn and permit them to seek dissolution in the mold.

The jungle was bright with flowers, but it was a sinister brightness--a poisonous, threatening flash of pigment, set off by the blackness of the shadows. Heliconia spikes gleamed like fixed scarlet lightning, zigzagging through the pungent air. Now and then a bunch of pleasing, warm-hued berries reminded one of innocuous currants, but a second glance showed them ripening into swollen, liver-hued globes which 
offered no temptation to taste. One tree dangled hideous purple eups filled with vermilion fruits, and not far away the eolor sequence was reversed. A low-growing, pleasant-leaved plant lifted bursting masses of purple-blaek, all dripping like wounds upon the foliage below. Many flowers were unreeognizable save by their fragrance and naked stamens, advertised neither by eolor nor form of blossom. I despaired of flowers worthy of the name, until elose by my foot I saw a tiny plant with a comely, sweet-seented blossom, grateful to the eye and beautiful as our northern blooms are beautiful. The leaf was like seores lying about, and I realized that this was a sproutling of the giant tree. Nothing but the death of this monster could give the light and air which the little plant needed. It was doomed, but it had performed its destiny. It had hinted that much of the beauty of the jungle lay far above the mold and stagnant water. And then I remembered the orchids high overhead. And the realization came that the low-growing blooms needed their glaring colors to outshine the dim, shadowy underjungle, and their nauseous fumes to outscent the musky vapors of decay. 
The plants of the jungle won success either by elbowing their neighbors and fighting their path up to sunlight, or else by adapting their needs to the starvation meed of air and light allotted to the lowly growths. The big-leaved churacas had found another means of existence. They lived like permanent rockets, bursting in mid-air. A long, curved stem shot up and reached far out into space. It was so slender as to be almost invisible in the dim light. At its tip radiated a great burst of foliage, leaves springing out in all directions, and absorbing nutrition which a sapling growing amid the undergrowth could not possibly do.

From daybreak to dark the canella tree was seldom deserted. Usually a score or more birds fluttered and fed among its branches, and true to tropic laws, there were comparatively few individuals but a multitude of species. In the few hour's I was able to devote to its study, I identified seventy-six different kinds, and together with those which I saw but could not name, I judge that more than a hundred species must have come to the berries during that week in early May. The first day I secured sixteen specimens, all different; and the following day 
yielded fourteen more, only one of which was a duplicate of the first day's results.

The bird visitors to the tree arrived in one of two characteristic ways. Many came direct and swiftly, singly or in pairs, flying straight and with decision. These came from a distance, with full knowledge of the berries. They fed quietly, and when satiated flew off. The second method of arrival was wholly casual,-loose flocks drifting slowly from the neighboring jungle, sifting into the tree, and feeding for a time before passing on. When these left it was rather hastily, and in answer to the chirps and calls of the members of their flock who had not been beguiled by the berries and hence had forged steadily ahead.

These more or less well-defined flocks are very characteristic of all tropical jungles. Little assemblages of flycatchers, callistes, tanagers, antbirds, manakins, woodhewers, and woodpeckers are drawn together by some intangible but very social instinct. Day after day they unite in these fragile fraternities which drift along, gleaning from leaves, flowers, branches, trunks, or ground, each bird according to its structure and way of life. They are so held together by an 
intangible gregarious instinct that day after day the same heterogeneous flock may be observed, identifiable by peculiarities of one or several of its members. The only recognizable bond is vocal-a constant low calling; half unconscious, absent-minded little signals which keep the members in touch with one another, spurring on the laggards, retarding the overswift.

While I watched, there came to my tree a single species of pigeon, two hawks, and two parrots, four hummingbirds, and an equal number of toucans and woodpeckers. The remaining fifty-nine were all passerine birds, of which there were eight each of the families of flycatchers, manakins, and cotingas. Eleven were tanagers.

The greedy, noisy parrakeets were always the center of commotion, wasting more berries than they ate. The toucans, those bizarre birds of whose lives we know so little, yelped and called and bathed in the water caught in the stubs of branches, and fed to repletion. All the flycatchers forgot their usual diet and took to berrying as ardently as the tanagers themselves. Not all the birds came to feed on the berries. A wren hunted insects among the branches, and 
a hawk found a giant snail crawling up the trunk and devoured it. The insect-eaters of the trunk numbered nine and showed no interest in the berries. 'Two were woodpeckers and seven woodhewers.

These latter are a strange tropical family four hundred strong, and all the very essence of protective coloring. Their habits of life make of them wandering bits of bark, easy to detect when they are in motion, but vanishing utterly when they are quiet. Their similarity in dress is remarkable. They may be large or small, short or long-tailed, with beaks blunt, sharp, straight, curved, thick, or needle-pointed. In these characters they differ; by these points they must know one another. But their colors are almost identical. Their olives or browns invariably warm into rich foxy rufous on wings and tail, while over head and shoulders a shower of light streaks has fallen, bits of sunlight fixed in down.

Further details belong to the literature of ornithology. But the colors of the berry-huntersthese baffle description, yet we cannot pass them by in silence. The blood and orange splashed on black of the toucans, the scarlet and yellow 
of woodpeckers, the soft greens and buffs of flycatchers, all these paled when a flock of manakins or tanagers or honeycreepers came to the tree. Every precious stone found its counterpart in the metallic hues of these exquisite feathered folk.

The glory of all was the opal-crowned manakin, a midget in green coat and sulphur waistcoat, with a cap of scaly, iridescent, silvery mother-of-pearl plates, in no way akin to feathers. Until now the life of this Hop o' my Thumb, like those of all his ancestors, had gone smoothly on, with never a human to admire, to wonder, and vainly to echo the question of the great black frog, Wh-y?

On the last day of my stay I walked slowly up the trail toward the canella do matto. For the last time I strained upward at the wellknown branches, and with the very movement there came the voice of the swamp. Its tone was insistent, with a tinge of accusation, a note of censure. Wh-y? and after a little time, Wh-y?

I looked about me despairingly. What had I learned after all? Was there any clearing up of the mystery of the jungle? Had my week 
of scrutiny brought me any closer to the real intimacies of evolution? Or-evading these questions for the time-was there nothing I could do in the few precious moments left?

In five minutes I should turn my back on all this wildness, this jungle seething with profound truths, and great solutions within arm's reach. I should pass to the ocean where monotony compels introspection, and finally to the great center of civilization where the veneer covers up all truths.

Even if my studies had taught only the lesson of the tremendous insurgence of life, could I not emphasize this, make it a more compelling factor to be considered in future efforts toward the frog's question and mine?

My eyes left the foliage overhead and sought the ground. Acting on impulse, I brought from my camping stores an empty war-bag, and scraped together an armful of leaves, sticks, moss, earth, mold of all sorts. Four square feet of jungle débris went into my bag, and I shouldered it.

Then I said adieu to my trail and my tree-a sorrowful leave-taking, as is always my misfortune. For the bonds which bind me to a place 
or a person are not easily broken. And, as usual when the trail passed from view, the ideal alone remained, 'The thoughts of mosquitoes, of drenchings, of hours of breathless disappointed waiting, all sank in the memory of the daily discoveries, the mental delights of new research.

A week later, when the sky-line was unbroken by land, when a long ground-swell waved but did not disturb the deep blue of the open sea, I unlaced my bag of jungle mold. Armed with forceps, lens, and vials I began my search. For days I had gazed upward; now my scrutiny was directed downward. With binoculars I had scanned without ceasing the myriad leaves of a great tree; now with lens or naked eye I sought for life or motion on single fallen leaves and dead twigs. When I studied the life of the great tree I was in the land of Brobdingnag; now I was verily a Gulliver in Lilliput. The cosmos in my war-bag teemed with mystery as deep and as inviting as any in the jungle itself.

When I began work I knew little of what I should find. My vague thoughts visualized ants and worms, and especially I anticipated unearthing myriads of the unpleasant "mucuims" 
or bêtes rouges, whose hosts had done all in their power to make life in the jungle unhappy.

Day by day my vials increased. Scores of creatures evaded my search; many others, of whose kind I had captured a generous number, I allowed to escape.

My lilliputian census was far from the mere aggregation of ants and worms which I had anticipated, and a review of the whole showed that hardly any great group of living creatures was unrepresented.

As hinting of the presence of wild animals, a bunch of rufous hairs had in some way been tweaked from a passing agouti. Man himself was represented in the shape of two wads which had dropped from my gun-shots some time during the week. One had already begun to disintegrate and sheltered half a dozen diminutive creatures. Five feathers were the indications of birds, two of which were brilliant green plumes from a calliste. Of reptiles there was a broken skull of some lizard, long since dead, and the eggshell of a lizardling which had hatched and gone forth upon his mission into the jungle. A third reptilian trace may have been his nemesis-a bit of shed snake-skin. The group of 
amphibians was present even in this square of four feet-a very tiny, dried, black, and wholly unrecognizable little frog. Fishes were absent, though from my knees as I scraped up the débris, I could almost have seen a little igarapé in which dwelt scores of minnows.

As I delved deeper and examined the mold more carefully for the diminutive inhabitants, I found that this thin film from the floor of the jungle appeared to have several layers, each with its particular fauna. The upper layer was composed of recently fallen leaves, nuts, seeds, and twigs, dry and quite fresh. Here were colonies of small ants and huge, solitary ones; here lived in hiding small moths and beetles and bugs, awaiting dusk to fly forth through the jungle. The middle layer was by far the most important, and in it lived four fifths of all the small folk. The lowest layer was one of matted roots and clayey soil and its animal life was meager.

Between the upper and the middle strata were sprouting nuts and seeds, with their blanched roots threaded downward into the rich dark mold, and the greening cotyledons curling upward toward light and warmth. Thus had the 
great bird-filled canella begun its life. In my war-bag were a score of potential forest giants doomed to death in the salt ocean. But for my efforts toward the $W h-y$, their fate might have been very different.

Some of the half-decayed leaves were very beautiful. Vistas of pale, bleached fungus lace trailed over the rich mahogany-colored tissues, studded here and there with bits of glistening, transparent quartz. Here I had many hints of a world of life beyond the power of the unaided eye. And here too the grosser fauna scrambled, hopped, or wriggled. Everywhere were tiny chrysalides and cocoons, many empty. Now and then a plaque of eggs, almost microscopic, showed veriest pin-pricks where still more minute parasites had made their escape. When one contracted the field of vision to this world where leaves were fields and fungi loomed as forests, competition, the tragedies, the mystery lessened not at all. Minute seeds mimicked small beetles in shape and in exquisite tracery of patterns. Bits of bark simulated insects, a patch of fungus seemed a worm, while the mites themselves were invisible until they moved. Here and there I discovered a lifeless boulder of 
emerald or turquoise-the metallic cuirass of some long-dead beetle.

Some of the scenes which appeared as I picked over the mold, suddenly unfolding after an upheaval of débris, were like Aladdin's cave. Close to the eye appeared great logs and branches protruding in confusion from a heaped up bank of diamonds. Brown, yellow, orange, and white colors played over the scene; and now over a steep hill came a horrid, ungainly creature with enormous proboscis, eight legs, and a shining, liver-colored body, spotted with a sickly hue of yellow. It was studded with short, stiff, horny hairs-a mite by name, but under the lens a terrible monster. I put some of these on my arm, to see if they were the notorious "mucuims" which tortured us daily. Under the lens I saw the hideous creature stop in its awkward progress, and as it prepared to sink its proboscis I involuntarily flinched, so fearful a thing seemed about to happen.

The lesser organisms defy description. They are nameless except in the lists of specialists, and indeed most are of new, quite unnamed forms. The only social insects were small twigfuls of ant and termite colonies, with from five 
to fiftecn members. All others were isolated, scattered. Life here, so far beneath the sunlight, is an individual thing. Flocks and herds are unknown; the mob has no place here. Each tiny organism must live its life and meet its fate single-handed.

Little pseudo-scorpions were very abundant, and I could have vialed hundreds. They rushed out excitedly and, unlike all the other little beings, did not seek to hide. Instead, when they were disturbed, they sought open spaces, walking slowly and brandishing and feeling ahead with their great pincer-tipped arms, as long as their entire body. When irritated or frightened, they scurried backwards, holding up their chelæ in readiness.

Mites were the most abundant creatures, equaling the ants in number, always crawling slowly along, tumbling over every obstacle in their path and feeling their way awkwardly. Their kinds were numerous, all villainous in appearance. Ticks were less common but equally repellant. Small spiders and beetles were occasionally found, and hundred-legged wrigglers fled to shclter at every turn of a leaf. The smallest snails in the world crawled slowly about, 
some flat-shelled, others turreted. Tiny earthworms, bright red and very active, crept slowly through fungus jungles until disturbed, when they became an amazingly active tangle of twisting curves, dancing all about. Simple insects, which we shall have to call collembolas, were difficult to capture. They leaped with agility many times their own length, and when quiescent looked like bits of fungus. As for the rest, only Adam and a few specialists hidden in museums could call them by name. They were a numerous company, some ornamented with weird horns and fringes and patterns, others long of legs or legless, swift of foot or curling up into minute balls of animate matter.

One thing was evident early in my exploration: I was in a world of little people. No large insects were in any of the débris. 'The largest would be very small in comparison with a May beetle. And another thing was the durability of chitin. The remains of beetles, considering the rareness of living ones, were remarkable. The hard wing-cases, the thorax armor, the segments of wasps, eyeless head masks, still remained perfect in shape and vivid in color. Even in the deepest layers where all else had 
disintegrated and returned to the elements, these shards of death were as new.

And the smell of the mold, keen and strong as it came to my nostriis an inch away-it was pungent, rich, woody. It hinted of the age-old dissolution, century after century, which had been going on. Leaves had fallen, not in a sudden autumnal downpour, but in a never-ending drift, day after day, month after month. With a daily rain for moisture, with a temperature of three figures, for the quicker increase of bacteria, and an excess of humidity to foster quick decay, the jungle floor was indeed a laboratory of vital work-where only analytic chemistry was allowed full sway, and the mystery of synthetic life was ever handicapped, and ever a mystery.

Before the vessel docked I had completed my task and had secured over five hundred creatures of this lesser cosmos. At least twice as many renuained, but when I made my calculations I estimated that the mold had sheltered only a thousand organisms plainly visible to the eye.

And when I had corked my last vial and the steward had removed the last pile of shredded débris, I leaned back and thought of the thousand 
creatures in my scant four square feet of mold. Then there came to mind a square mile of jungle floor with its thin layer of fallen leaves sheltering more than six billion creatures. Then I recalled the three thousand straight miles of jungle which had lain west of me, and the hundreds of miles of wonderful unbroken forest north and south, and my mind became a blank. And then from the mist of unnamable numerals, from this uncharted arithmetical census, there came to memory a voice, deep and guttural,and this time the slow enunciation was jeering, hopeless of answer, Wh-y? And soon afterwards, Wh-y? And I packed up my last box of vials and went on deck to watch the sunset. 


\section{XI}

\section{JUNGLE NIGHT}

Withis gun-reach in front of me trudged my little Akawai Indian hunter. He turned his head suddenly, his ears catching some sound which mine had missed, and I saw that his profile was rather like that of Dante. Instantly the thought spread and the simile deepened. Were we two not all alone? and this unearthly hour and light-Then I chuckled softly, but the silence that the chuckle shattered shrank away and made it a loud, coarse sound, so that I involuntarily drew in my breath. But it was really amusing, the thought of Dante setting out on a hunt for kinkajous and giant armadillos. Jeremiah looked at me wonderingly, and we went on in silence. And for the next mile Dante vanished from my thoughts and I mused upon the sturdy little red man. Jeremiah was his civilized name; he would never tell me his real one. It seemed so unsuited to him that I 
thought up one still less appropriate and called him Nupee-which is the three-toed sloth; and in his quiet way he saw the humor of it, for a more agile human being never lived.

Nupee's face was unclouded, but his position as hunter to our expedition had brought decisions and responsibilities which he had not known before. The simple life,- the unruffled existence in the little open benab, with hammock, cassava field, and an occasional hunt,-this was of the past. A wife had come, slipping quietly into his life, Indian-fashion; and now, before the baby arrived, decisions had to be made. Nupee longed for some store shoes and a suit of black clothes. He had owned a big benab which he himself had built; but a godmother, like the cowbird in a warbler's nest, had gradually but firmly ousted him and had filled it with diseased relatives, so that it was unpleasant to visit. He now, to my knowledge, owned a single shirt and a pair of short trousers.

The shoes were achieved. I detected in him qualities which I knew that I should find in some one, as I do on every expedition, and I made him perform some unnecessary labor and gave him the shoes. But the clothes would cost five 
dollars, a month's wages, and he had promised to get married-white-fashion-in another month, and that would consume several times five dollars. I did not offer to help him decide. His Akawai marriage ceremony seemed not without honor, and as for its sincerity-I had seen the two together. But my lips were sealed. I could not tell him that a recementing of the ritual of his own tribe did not seem quite the equal of a five-dollar suit of clothes. That was a matter for individual decision.

But tonight I think that we both had put all our worries and sorrows far away, and I memory as well; and I felt sympathy in the quiet, pliant gait which carried him so swiftly over the sandy trail. I knew Nupee now for what he was-the one for whom I am always on the lookout, the exceptional one, the super-servant, worthy of friendship as an equal. I had seen his uncle and his cousins. They were Indians, nothing more. Nupee had slipped into the place left vacant for a time by Aladdin, and by Satán and Shimosaka, by Drojak and Trujillo-all exceptional, all faithful, all servants first and then friends. I say "for a time," for all hoped, and I think still hope with me, that we shall 
meet and travel and camp together again, whether in the Cinghalese thornbush, or Himalayan dâks, in Dyak canoes or among the camphor groves of Sakarajama.

Nupee and I had not been thrown together closely. This had proved a static expedition, settled in one place, with no dangers to speak of, no real roughing it, and we met only after each hunting trip. But the magic of a full moon had lured me from my laboratory table, and here we were, we two, plodding junglewards, becoming better acquainted in silence than $I$ have often achieved with much talk.

It was nearly midnight. We traversed a broad trail of white sand, between lines of saplings of pale-barked rubber trees, flooded, saturated, with milky-gray light. Not a star appeared in the cloudless sky, which, in contrast to the great silver moon-plaque, was blue-black, These open sandy stretches, so recently etched into what had been primitive jungle, were too glowing with light for most of the nocturnal creatures who, in darkness, flew and ran and hunted about in them. And the lovers of twilight were already come and gone. The stage was vacant save for one actor-the nighthawk 
of the silvery collar, whose eerie roheceo! or more leisurely and articulate who-are-you? was queried from stump and log. There was in it the same liquid tang, the virile ringing of skates on ice, which enriches the cry of the whip-poorwill in our country lanes.

Where the open trail skirted a hillside we came suddenly upon a great gathering of these goatsuckers, engaged in some strange midnight revel. Usually they roost and hunt and call in solitude, but here at least forty were collected on the white sand within an area of a few yards. We stopped and waiched. They were dancing -or, rather, popping, as corn pops in a hopper. One after another, or a half dozen at a time, they bounced up a foot or two from the ground and flopped back, at the instant of leaving and returning uttering a sudden, explosive rwop! This they kept up unceasingly for the five minutes we gave to them, and our passage interrupted them for only a moment. Later we passed single birds which popped and wopped in solitary state; whether practicing, or snobbishly refusing to perform in public, only they could tell. It was a scene not soon forgotten.

Suddenly before us rose the jungle, raw- 
edged, with border zone of bleached, ashamed trunks and lofty branches white as chalk, of dead and dying trees. For no jungle tree, however hardy, can withstand the blasting of violent sun after the veiling of emerald foliage is torn away. As the diver plunges beneath the waves, so, after one glance backward over the silvered landscape, I passed at a single stride into what seemed by contrast inky blackness, relieved by the trail ahead, which showed as does a ray of light through closed eyelids. As the chirruping rails climbed among the roots of the tall cat-tails out yonder, so we now crept far beneath the level of the moonlit foliage. The silvery landscape had been shifted one hundred, two hundred feet above the earth. We had become lords of creation in name alone, threading our way humbly among the fungi and toadstools, able only to look aloft and wonder what it was like. And for a long time no voice answered to tell us whether any creature lived and moved in the tree-tops.

The tropical jungle by day is the most wonderful place in the world. At night I an sure it is the most weirdly beautiful of all places outside the world. For it is primarily unearthly, 


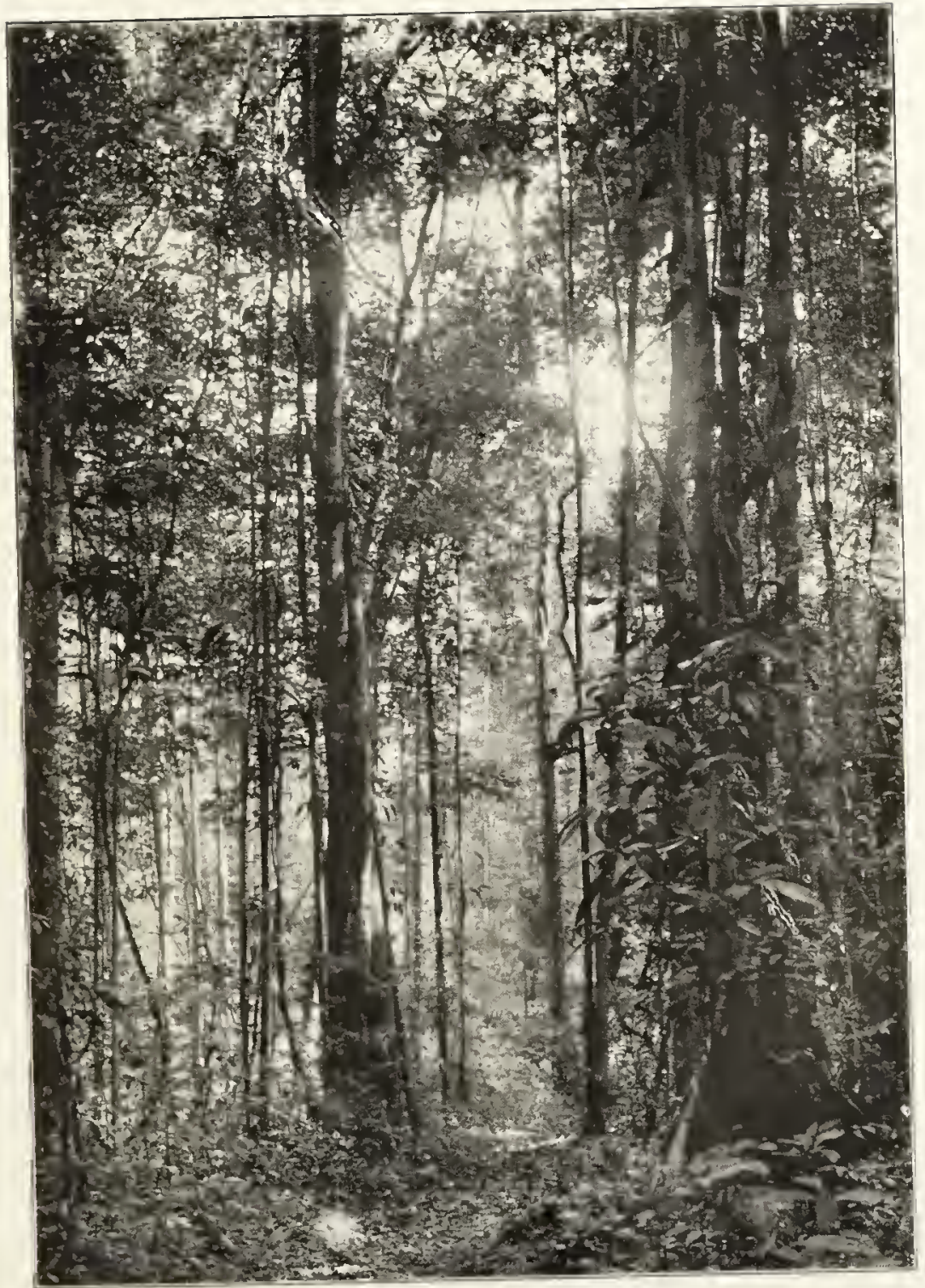

The dungle 

unreal; and at last I came to know why. In the light of the full moon it was rejuvenated. The simile of theatrical scenery was always present to the mind, the illusion lying especially in the completeness of transformation from the jungle by daylight. The theatrical effect was heightened by the sense of bcing in some vast building. This was because of the complete absence of any breath of air. Not a leaf moved; even the pendulous air-roots reaching down their seventy-foot plummets for the touch of soil did not sway a hair's breadth. The throb of the pulse set the rhythm for one's steps. The silence, for a time, was as perfect as the breathlessness. It was a wonderfully ventilated amphitheatcr; the air was as free from any feeling of tropical heat, as it lacked all crispness of the north. It was exactly the temperature of one's skin. Heat and cold were for the moment as unthinkable as wind.

One's body seemed wholly negligible. In soft padding moccasins and easy swinging gait close behind my naked Indian hunter, and in such khaki browns that my body was almost invisible to my own downward glance, I was conscious only of the play of my senses-of two at first, 
sight and smell; later, of hearing. The others did not exist. We two were unattached, impersonal, moving without effort or exertion. It was magic, and I was glad that I had only my Akawai for companion, for it was magic that a word would have shattered. Yet there was this wonderfully satisfying thing about it, that most magic lacks: it exists at present, today perhaps, at least once a month, and I know that I shall experience it again. When I go to the window and look out upon the city night, I find all extraneous light emaciated and shattered by the blare of gas and electricity, but from one upreaching tower I can see reflected a sheen which is not generated in any power-house of earth. Then I know that within the twenty-four hours the terai jungles of Garhwal, the tree-ferns of Pahang, and the mighty moras which now surround us, will stand in silvery silence and in the peace which only the wilderness knows.

I soon took the lead and slackened the pace to a slow walk. Every few minutes we stood motionless, listening with mouth as well as ears. For no one who has not listened in such silence can realize how important the mouth is. Like the gill of old which gave it origin, our ear has 
still an entrance inward as well as outward, and the sweep of breath and throb of the blood are louder than we ever suspect. When at an opera or concert I see some one sitting rapt, listening with open mouth, I do not think of it as illbred. I know it for unconscious and sincere absorption based on an excellent physical reason.

It was early spring in the tropics; insect life was still in the gourmand stage, or that of pupal sleep. The final period of pipe and fiddle had not yet arrived, so that there was no hum from the underworld. The flow of sap and the spread of petals were no less silent than the myriad creatures which, I knew, slumbered or hunted on every side. It was as if I had slipped back one dimension in space and walked in a shadow world. But these shadows were not all colorless. Although the light was strained almost barren by the moon mountains, yet the glow from the distant lava and craters still kept something of color, and the green of the leaves, great and small, showed as a rich dark olive. The afternoon's rain had left each one filmed with clear water, and this struck back the light as polished silver. There was no tempered illumi- 
nation. The trail ahead was either black, or a solid sheet of light. Here and there in the jungle on each side, where a tree had fallen, or a flue of clear space led moonwards, the effect was of cold electric light seen through trees in city parks. When such a shaft struck down upon us, it surpassed simile. I have seen old paintings in Belgian cathedrals of celestial light which now seems less imaginary.

At last the silence was broken, and like the first breath of the tradewind which clouds the Mazaruni surface, the mirror of silence was never quite clear again-or so it seemed. My northern mind, stored with sounds of memory, never instinctively accepted a new voice of the jungle for what it was. Each had to go through a reference clearing-house of sorts. It was like the psychological reaction to words or phrases. Any strange wail or scream striking suddenly upon my ear instantly crystallized some vision of the past-some circumstance or adventure fraught with similar sound. Then, appreciably as a second thought, came the keen concentration of every sense to identify this new sound, to hear it again, to fix it in mind with its character and its meaning. Perhaps at some distant 
place and time, in utterly incongruous surroundings, it may in turn flash into consciousness-a memory-simile stimulated by some sound of the future.

I stood in a patch of moonlight listening to the baying of a hound, or so I thought: that musical ululation which links man's companion wolfwards. Then I thought of the packs of wild hunting dogs, the dreaded "warracabra tigers," and I turned to the Indian at my elbow, full of hopeful expectation. With his quiet smile he whispered, "kunama," and I knew I had heard the giant tree-frog of Guiana-a frog of size and voice well in keeping with these mighty jungles. I knew these were powerful becnas with the Indians, tokens of good hunting, and every fortunate benab would have its dried mummy frog hung up with the tail of the giant armadillo and other charms. Well might these batrachians arouse profound emotions among the Indians, familiar as they are with the strange beings of the forest. I could imagine the great goggle-eyed fellow sprawled high near the roof of the jungle, clutching the leaves with his vacuum-cupped toes. The moonlight would make him ghostly - a pastel frog; 
but in the day he flaunted splashes of azure and green on his scarlet body.

At a turn in the trail we squatted and waited for what the jungle might send of sight or sound. And in whispers Nupee told me of the big frog kunama, and its ways. It never came to the ground, or even descended part way down the trees; and by some unknown method of distillation it made little pools of its own in deep hollows and there lived. And this water was thick like honey and white like milk, and when stirred became reddish. Besides which, it was very bitter. If a man drank of it, forever after he hopped each night and clasped all the trees which he encountered, endlessly endeavoring to ascend them and always failing. And yet, if he could once manage to reach a pool of kunama water in an uncut tree and drink, his manhood would return and his mind be healed.

When the Indians desired this beena, they marked a tree whence a frog called at night, and in the daytime cut it down. Forming a big circle, they searched and found the frog, and forthwith smoked it and rubbed it on arrows and bow before they went out. I listened gravely and found it all fitted in with the magic 
of the night. If an Indian had appeared down the trail, hopping endlessly and gripping the trunks, gazing upward with staring eyes, I should not have thought it more strange than the next thing that really happened.

We had settled on our toes in another squatting-place-a dark aisle with only scattered flecks of light. The silence and breathlessness of the mooncraters could have been no more complete than that which enveloped us. My eye wandered from spot to spot, when suddenly I began to think of that great owl-like goatsucker, the "poor-me-one." We had shot one at Kalacoon a month before and no others had called since, and I had not thought of the species again. Quite without reason I began to think of the bird, of its wonderful markings, of the eyes which years ago in Trinidad $I$ had made to glow like iridescent globes in the light of a flash, and then-a poor-me-one called behind us, not fifty feet away. Even this did not seem strange among these surroundings. It was an interesting happening, one which I have experienced many times in my life. It may have been just another coincidence. I am quite certain it was not. In any event it was a Dantesque 
touch, emphasized by the character of the callthe wail of a lost soul being as good a simile as any other. It started as a high, trembling wail, the final cry being lost in the depths of whispered woe:-

\section{Oo-ooh!}

oh!

oh!

oh!

oh!

oh!

Nupee never moved; only his lips formed the name by which he knew it-halawoe. Whatever else characterized the sounds of the jungle at night, none became monotonous or common. Five minutes later the great bird called to us from far, far away, as if from another round of purgatory-an eerie lure to enter still deeper into the jungle depths. We never heard it again.

Nature seems to have apportioned the voices of many of her creatures with sensitive regard for their environment. Somber voices seem fittingly to be associated with subdued light, and joyous notes with the blaze of sunlit twigs and open meadows. A bobolink's bubbling carol is 
unthinkable in a jungle, and the strain of a wood pewee on a sunny hillside would be like an organ playing dance music. This is even more pronounced in the tropics, where, quite aside from any mental association on my part, the voices and calls of the jungle reflect the qualities of that twilight world. The poor-meone proves too much. He is the very essence of night, his wings edged with velvet silence, his plumage the mingled concentration of moss and lichens and dead wood.

I was about to rise and lead Nupee farther into the gloom when the jungle showed another mood-a silent whimsy, the humor of which I could not share with the little red man. Close to my face, so near that it startled me for a moment, over the curved length of a long narrow caladium leaf, there came suddenly two brilliant lights. Steadily they moved onward, coming up into view for all the world like two tiny headlights of a motor-car. They passed, and the broadside view of this great elater was still absurdly like the profile of a miniature tonneau with the top down. I laughingly thought to myself how perfect the illusion would be if a red tail-light should be shown, when 
to my amazement a rosy red light flashed out behind, and my bewildered eyes all but distinguished a number! Naught but a tropical forest could present such contrasts in such rapid succession as the poor-me-one and this parody of man's invention.

I captured the big beetle and slid him into a vial, where in his disgust he clicked sharply against the glass. The vial went into my pocket and we picked up our guns and crept on. As we traversed a dark patch, dull gleams like heat lightning flashed over the leaves, and, looking down, I saw that my khaki was aglow from the illuminated insect within. This betrayed every motion, so I wrapped the vial in several sheets of paper and rolled it up in my handkerchief. The glow was duller but almost as penetrating. At one time or another I have had to make use of all my garments, from topee to moccasins, in order to confine captives armed with stings, beaks, teeth, or fangs, but now I was at a complete loss. I tried a gun-barrel with a handkerchief stopper, and found I now carried an excellent, long-handled flashlight. Besides, I might have sudden use for the normal function of the gun. I had nothing sufficiently opaque to 
quench those flaring headlights, and I had to own myself beaten and release him. He spread his wings and flew swiftly away, his red light glowing derisively; and even in the flood of pure moonlight he moved within an aura which carried far through the jungle. I knew that killing him was of no use, for a week after death from chloroform $I$ have seen the entire interior of a large insect box brilliantly lighted by the glow of these wonderful candles, still burning on the dead shoulders of the same kind of insect.

Twice, deeper in the jungle we squatted and listened, and twice the silence remained unbroken and the air unmoved. Happening to look up through a lofty, narrow canyon of dark foliage, I was startled as by some sudden sound by seeing a pure white cloud, moon-lit, low down, pass rapidly across. It was first astounding, then unreal: a bit of exceedingly poor work on the part of the property man, who had mixed the hurricane scenery with that of the dog-days. Even the elements seemed to have been laved with magic. The zone of high wind with its swift flying clouds must have been flowing like a river just above the motionless foliage of the tree-tops. 
This piece of ultra-unnaturalism seemed to break part of the spell and the magic silence was lifted. Two frogs boomed again, close at hand, and now, all the hound similitude was gone, and in its place another, still more strange, when we think of the goggle-eyed author far up in the trees. The sound now was identical with the short cough or growl of a hungry lion, and though I have heard the frogs many times since that night, this resemblance never changed or weakened. It seemed as if the volume, the roaring outburst, could come only from the throat of some large, full-lunged mammal.

A sudden tearing rush from the trail-side, and ripping of vines and shrubs, was mingled with deep, hoarse snorts, and we knew that we had disturbed one of the big red deer-big only in comparison with the common tiny brown brockets. A few yards farther the leaves rustled high overhead, although no breath of wind had as yet touched the jungle. I began a slow, careful search with my flashlight, and, mingled with the splotches and specks of moonlight high overhead, I seemed to see scores of little eyes peering down. But at last my faint electric beam found its mark and evolved the first bit 


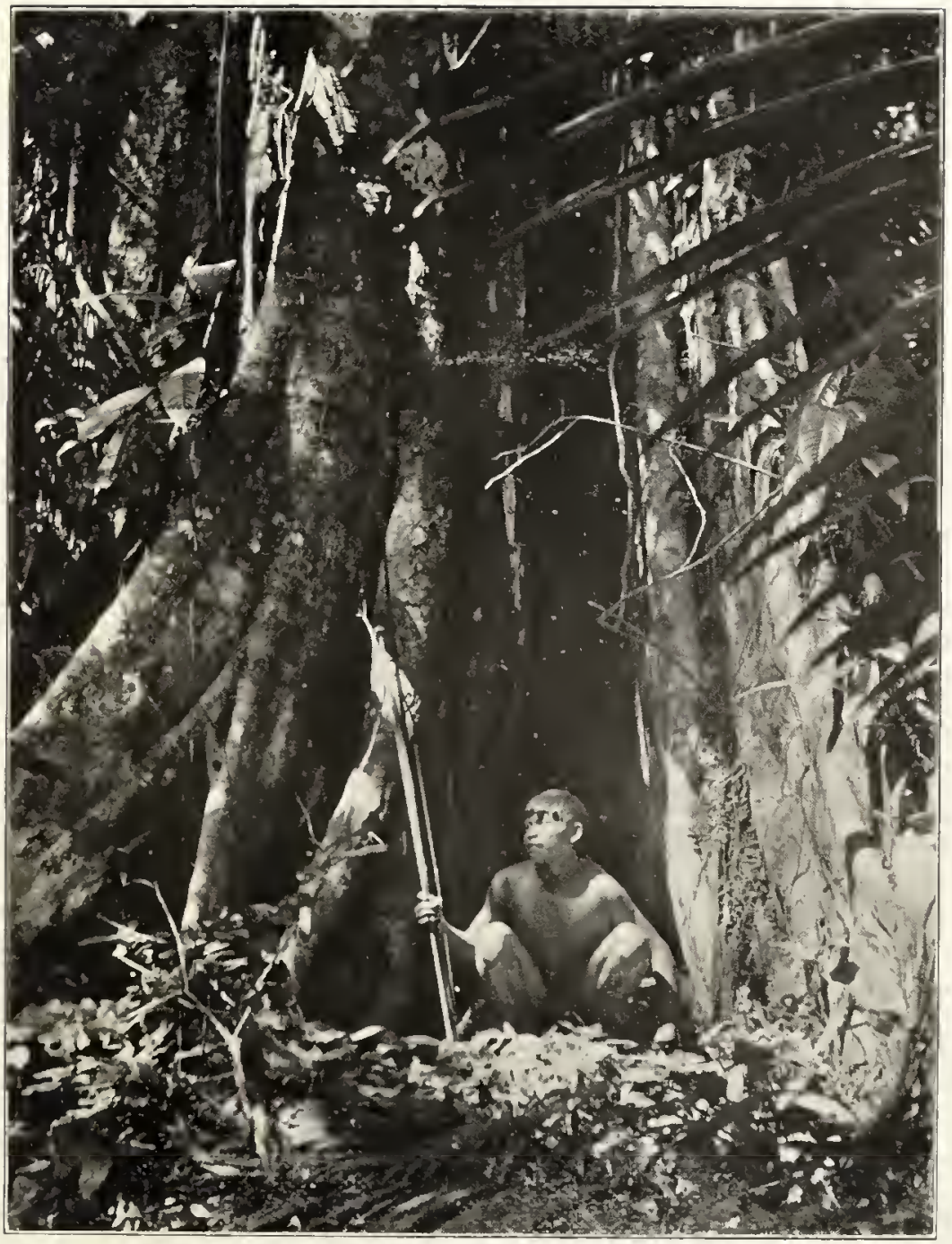

A Watcher in the Jungle 

of real color which the jungle had shownalways excepting the ruby tail-light. 'Two tiny red globes gleamed down at us, and as they gleamed, moved without a sound, apparently unattached, slowly through the foliage. Then came a voice, as wandering, as impersonal as the eyes-a sharp, incisive wheeeeeat! with a cat-like timbre; and from the eyes and voice I reconstructed a night monkey-a kinkajou.

Then another notch was slipped and the jungle for a time showed something of the exuberance of its life. A paca leaped from its meal of nuts and bounced away with quick, repeated pats; a beetle with wings tuned to the bass clef droned by; some giant tree-cricket tore the remaining intervals of silence to shreds with unmuted wing-fiddles, cricks so shrill and high that they well-nigh passed beyond the upper register of my ear out again into silence. The roar of another frog was comforting to my eardrums.

Then silence descended again, and hours passed in our search for sound or smell of the animal we wished chiefest to find-the giant armadillo. Thesc rare beings have a distinct 
odor. Months of work in the open had sharpened my nostrils so that on such a tramp as this they were not much inferior to those of Nupee. This sense gave me as keen pleasure as eye or ear, and furnished quite as much information. The odors of city and civilization seemed very far away: gasolene, paint, smoke, perfumery, leather-all these could hardly be recalled. And how absurd seemed society's unwritten taboo on discussion of this admirable, but pitifully degenerate sense! Why may you look at your friend's books, touch his collection of netsukés, listen to his music, yet dare sniff at naught but his blossoms!

In the open spaces of the earth, and more than anywhere in this conservatory of unblown odors, we come more and more to appreciate and to envy a dog's sensitive muzzle. Here we sniffed as naturally as we turned ear, and were able to recognize many of our nasal impressions, and even to follow a particularly strong scent to its source. Few yards of trail but had their distinguishable scent, whether violent, acrid smell or delectable fragrance. Long after a crabjackal had passed, we noted the stinging, bitter taint in the air, and now and then the pungent 
wake of some big jungle-bug struck us like a tangible barrier.

The most tantalizing odors were the wonderfully delicate and penetrating ones from some great burst of blossoms, odors heavy with sweetness, which seeped down from vine or tree high overhead, wholly invisible from below even in broad daylight. These odors remained longest in memory, perhaps because they were so completely the product of a single sense. There were others too, which were unforgetable, because, like the voice of the frog, they stirred the memory a fraction before they excited curiosity. Such I found the powerful musk from the bed of leaves which a fawn had just left. For some reason this brought vividly to mind the fearful compound of smells arising from the decks of Chinese junks.

Along the moonlit trail there came wavering whiffs of orchids, ranging from attar of roses and carnations to the pungence of carrion, the latter doubtless distilled from as delicate and beautiful blossoms as the former. There were, besides, the myriad and bewildering smells of sap, crushed leaves, and decaying wood; acrid, sweet, spicy and suffocating, some like musty 
books, others recalling the paint on the Noah's Ark of one's nursery.

But the scent of the giant armadillo eluded us. When we waded through some new, strange odor I looked back at Nupee, hoping for some sign that it was the one we sought. But that night the great armored creatures went their way and we ours, and the two did not cross. Nupee showed me a track at the trail-side made long ago, as wide and deep as the spoor of a dinosaur, and I fingered it reverently as I would have touched the imprint of a recently alighted pterodactyl, taking care not to spoil the outlines of the huge claw-marks. All my search for him had been in vain thus far, though $I$ had been so close upon his trail as to have seen fresh blood. I had made up my mind not to give up, but it seemed as if success must wait for another year.

We watched and called the ghostly kinkajous and held them fascinated with our stream of light; we roused unnamable creatures which squawked companionably at us and rustled the tree-top leaves; we listened to the whispered rush of passing vampires skimming our faces and were soothed by the hypnotic droning hum 
which beetles left in their swift wake. Finally we turned and circled through side trails so narrow and so dark that we walked with outstretched arms, feeling for the trunks and lianas, choosing a sloth's gait and the hope of new adventures rather than the glare of my flash on our path.

When we entered the Convict Trail, we headed toward home. Within sight of the first turn a great black limb of a tree had recently fallen across the trail in a patch of moonlight. Before we reached it, the branch had done something it should not have done-it had straightened slightly. We strained our eyes to the utmost but could not, in this eerie light, tell head from tail end of this great serpent. It moved very slowly, and with a motion which perfectly confounded our perception. Its progress seemed no faster than the hour hand of a watch, but we knew that it moved, yet so close to the white sand that the whole trail seemed to move with it. The eye refused to admit any motion except in sudden shifts, like widely separated films of a motion-picture. For minute after minute it seemed quiescent; then we would blink and realize that it was two feet higher up the bank. One 
thing we could see-a great thickening near the center of the snake: it had fed recently and to repletion, and slowly it was making its way to some hidden lair, perhaps to lie motionless until another moon should silver the jungle. Was there any stranger life in the world?

Whether it was a giant bushmaster or a constrictor, we could not tell in the diffused light. I allowed it to go unharmed, for the spell of silence and the jungle night was too strongly woven to be shattered again by the crash of gun or rifle. Nupee had been quite willing to remain behind, and now, as so often with my savage friends, he looked at me wonderingly. He did not understand and I could not explain. We were at one in the enjoyment of direct phenomena; we could have passed months of intimate companionship in the wilds as I had done with his predecessors; but at the touch of abstract things, of letting a deadly creature live for any reason except for lack of a gun-then they looked at me always with that puzzled look, that straining to grasp the something which they knew must be there. And at once always followed instant acceptance, unquestioning, without protest. The transition was smooth, direct, com- 
plete; the sahib had had opportunity to shoot; he had not done so; what did the sahib wish to do now-to squat longer or to go on?

We waited for many minutes at the edge of the small glade, and the event which seemed most significant to me was in actual spectacle one of the last of the night's happenings. I sat with chin on knees, coolie-fashion-a position which, when once mastered, and with muscles trained to withstand the unusual flexion for hour after hour, is one of the most valuable assets of the wilderness lover and the watcher of wild things. It enables one to spend long periods of time in the lowest of umbrella tents, or to rest on wet ground or sharp stones where actual sitting down would be impossible. Thus is one insulated from bêtes rouges and enthusiastic ants whose sole motto is eternal preparedness. Thus, too, one slips as it were, under the visual guard of human-shy creatures, whose eyes are on the lookout for their enemy at human height. From such a position, a single upward leap prepares one instantly for advance or retreat, either of which manœuvers is well within instant necessity at times. Then there were always the two positions to which one could change if occasion 
required-flat-footed, with arm-pits on knees, or on the balls of the feet with elbows on knees. 'Thus is every muscle shifted and relaxed.

Squatting is one of the many things which a white man may learn from watching his shikarees and guides, and which, in the wilderness, he may adopt without losing caste. We are a chair-ridden people, and dare hardly even cross our knees in public. Yet how many of us enjoy sitting Buddha-fashion, or as near to it as we can attain, when the ban of society is lifted! A chairless people, however, does not necessarily mean a more simple, primitive type. The Japanese method of sitting is infinitely more difficult and complex than ours. The characters of our weak-thighed, neolithic forbears are as yet too pronounced in our own bodies for us to keep an upright position for long. Witness the admirable admittance of this anthropological fact by the architects of our subway cars, who know that only a tithe of their patrons will be fortunate enough to find room on the canebarked seats which have come to take the place of the stumps and fallen logs of a hundred thousand years ago. So they have thoughtfully strung upper reaches of the cars with imi- 
tation branches and swaying lianas, to which the last-comers cling jealously, and swing with morc or less of the grace of their distant forbears. 'Their fur, to be sure, is rubbed thinner; nuts and fruits have given place to newspapers and novels, and the roar and odors are not those of the wind among the leaves and blossoms. But the simile is amusing enough to end abruptly, and permit individual imagination to complete it.

When I see an overtired waiter or clerk swaying from foot to foot like a rocking elephant, I sometimes place the blame further back than immediate impatience for the striking of the closing hour. It were more true to blame the gentlemen whose habits were formed before caste, whose activities preceded speech.

We may be certain that chairs will never go out of fashion. We are at the end of bodily evolution in that direction. But to see a whitedraped, lanky Hindu, or a red-cloaked lama of the hills, quietly fold up, no matter where he may be, is to witness the perfection of chairless rest. One can read or write or doze comfortably, swaying slightly with a bird's unconscious balance, or, as in my case at present, wholly disarm suspicion on the part of the wild creatures 
by sinking from the height of a man to that of a jungle deer. And still I had lost nothing of the insulation which my moccasins provided from all the inconveniences of the forest floor. Looking at Nupee after this rush of chaotic thoughts which came betwcen jungle and happenings, I chuckled as I hugged my knees, for I knew that Nupee had noticed and silently considered my little accomplishment, and that he approved, and I knew that I had acquired merit in his sight. Thus may we revel in the approval of our super-servants, but they must never know it.

From this eulogy of squatting, my mind returned to the white light of the glade. I watched the motionless leaves about me, many of them drooping and rich maroon by daylight, for they were just unbudded. Reaching far into the dark mystery of the upper jungle stretched the air-roots, held so straight by gravity, so unheeding of the whirling of the planet through space. Only one mighty liana-a monkey-ladder-had revolted against this dominance of the earth's pull and writhed and looped upon itself in fantastic whorls, while along its length rippled ever the undulations which mark this uneasy growth, this crystallized Saint Vitus plant. 
A momentary shiver of leaves drew our eyes to the left, and we began to destroy the optical images evolved by the moon-shadows and to seek for the small reality which we knew lived and breathed somewhere on that branch. Then a sharp crack like a rifle lost whatever it was to us forever, and we half leapcd to our feet as something swept downward through the air and crashed length after length among the plants and fallen logs. The branches overhead rocked to and fro, and for many minutes, like the aftermath of a volcanic eruption, came a shower, first of twigs and swirling leaves, then of finer particles, and lastly of motes which gleamed like silver dust as they sifted down to the trail. When the air cleared I saw that the monkeyladder had vanished and I knew that its yards upon yards of length lay coiled and crushed among the ferns and sprouting palms of the jungle floor. It seemed most fitting that the vegetable kingdom, whose silence and majesty gave to the jungle night its magic qualities, should have contributed this memorable climax.

Long before the first Spaniard sailed up the neighboring river, the monkey ladder had thrown its spirals aloft, and through all the centuries, 
all the years, it had seen no change wrought beneath it. The animal trail was trod now and then by Indian hunters, and lately we had passed several times. The sound of our guns was less than the crashing fall of an occasional forest tree. Now, with no leaf moved by the air, with only the two of us squatting in the moonlight for audience, the last cell had given way. The sap could no longer fight the decay which had entered its heart; and at the appointed moment, the moment set by the culmination of a greater nexus of forces than our human mind could ever hope to grasp, the last fiber parted and the massive growth fell.

In the last few minutes, as it hung suspended, gracefully spiraled in the moonlight, it had seemed as perfect as the new-sprouted moras at my feet. As I slowly walked out of the jungle I saw in this the explanation of the simile of artificial scenery, of all the strange magic which had come to me as I entered. The alchemy of moonlight turned all the jungle to perfect growth, growth at rest. In the silvery light was no trace of gnawing worm, of ravening ant, or corroding fungus. The jungle was re'juvenated and made a place more wonderful 
than any fairyland of which I have read or which I have conceived. The jungle by day, as I have said-that, too, is wonderful. We may have two friends, quite unlike in character, whom we love each for his own personality, and yet it would be a hideous and unthinkable thing to see one transformed into the other.

So, with the mist settling down and tarnishing the great plaque of silver, I left the jungle, glad that I could be far away before the first hint of dawn came to mar the magic. Thus in memory I can always keep the dawn away until I return.

And some time in the future, when the lure of the full moon comes, and I answer, I shall be certain of finding the same silence, the same wonderful light, and the waiting trees and the magic. But Nupee may not be there. He will perhaps have slipped into memory, with Drojak and Aladdin. And if I find no one as silently friendly as Nupee, I shall have to watch alone through my jungle night. 



\section{INDEX}

Abary, 99

agouti, 189

allamandas, 85, 182

Amazon, 240

anaquas, 115

anchor, observation from, 22, 23

anis, 47, 100, 118

antbirds, 249

ants, 183, 256, 258; immunity from killing, 231 ; silvery gray, 223 ; "white," 233

army ants, behavior in rain, 228, 229; castes, 217 ; eyes, 219 ; leap, 212, 213, 223; methods of transportation, 215 , 229; moving of nest, 235,236 ; tube, 227; trail makers, 221, 222; virility, 234 ; weight lifted, 216

Barbados, 59-65

Bartica, 141

Basseterre, 45

bat, vampire, 104, 152

batrachian, 212

beach, $62,63,70,74,75$

Beckett, Mr., 124

becna, 274

bcetles, $211,227,234,256,277$; mimicry, 257 ; tiger, 63

bell bird, 159

Berbicc, 102, 103, 124

bete rouge, 243,255

blackbirds, 98,99

blackfish, 12

bougainvillea, 85

British Guiana, mission to, 67 ; coast lands, 92-102

bunduri pimpler, 125

bunyahs, yellow-backed, 100 bushmaster, noosing, 188-195; protcctive coloration, 191, 192; fangs, 194; sizc, 195

butterflies, on St. Thomas, 38 ; on St. Kitts, 48; migration of sulphur, 158

caciques, 100

cadouries, 146

callistes, 201, 249

canella do matto, 241

cashew, French, 197-200

caterpillars, aquatic, 128

catfish, armored, 112

cecropia, 182

centipedes, 152

cetaccans, 11

chachalacas, 157

churacas, 248

coal-carriers, St. Lucia, 55

convolvulus, 182

coolic, trial, 80-84; marriage, $163-176$

cotton-birds, 88

crabs, 16 ; land, 62

cricket, tree, 281

crows, carrion, 88

cuckoos, 212; black, 88

Cuyuni, 144

dacnis, 201

daddy-long-legs, 215, 227

dance, Hindu, 170

débris, jungle, 253

deer, 280

dikes, 97

dogs, wild hunting, 273

dolphins, 44, 45

doves, ground, 48

ducks, Muscovy, 88 
eclipsc, in Barbados, 61 egrets, 88

elater, 277

Essequibo, 144, 148

falcons, laughing, 88

fireflies, cluster, 210

fish, angel, 50, 56; four-eyed, 125; frog, 18; photographing of flying, 23; pipe, 18 flower, passion, 182

flycatchers, 249; fork-tailed, $122, \quad 159$; golden-crowned crested, 150 ; streaked, 196

frangipani, 85

frog, $211,212,240,273$; call, 240

gannets, 40

grass, bamboo, 183

grasshopper, 128, 212

grass-quits, 157

grass, razor, 179, 184

guide, for cutting trail, 187, 188

hanaquas, 119

hawks, 99

heliconias, 202; color, 204; Reds, 205; sleeping glade, 205 , 206; sleeping position, 205; Yellows, 205

herons, Guiana green, 127 ; tricolored, 88

hoatzins, 118, 119; call, 130; food of young, 126; home life, 123-139; nest, 126, 129; nestlings, 131; odor, 129; photographing young, 102, 103

honey creepers, 47, 252; turquoise, 201

hummingbirds, 38, 113, 197, 198, 199, 200

ibis, scarlet, 122

jackal, crab, 282

jaguar, 186 jungle, animals obtained from, 282 ; trail through, 89 ; yard of, 255

Kaburi trail, 148

Kalacoon, 142, 143

kingbirds, 47

kinkajous, 263, 281

kiskadees, 86, 104, 127, 157

kunama, 273; habits, 274

laboratory, wilderness, 141-153

lianas, 246

library, New Amsterdam, 105, 110

lichens, 196

lizards, in Barbados, 60 ; method of capture, 41-43; surrender of, 203 ; trail, 202 Jucannani, 157

maam, 189

Mafolie, 38

Mahaica, 99

manakins, 249 , 252; opalcrowned, 252

Martinique, 27-32, 49-54; mar,ket, 49-51

martins, $69,79,158$

Mazaruni, 144, 148

millipede, 38, 214

mimicry, 257

mites, 259

Monkey Hill, 47

monkcys, 48; howling, 155156

Mont Pelee, 27-32

moths, 256

mouse, 211

muckamucka, 125

New Amsterdam, 110, 124

nighthawk, call, 267; gathering, 267

noctiluca, 65

nuts, 75

opossum, 73,74

orioles, black-throated, 88; yellow, nest of, 100 
paca, 281

palms, cocoanut, 100

Pará, 241

parrakeets, 250

peas, butterfly, 182

perai, 90

phosphorescence, 20, 65

phosphorescent animals, method of capturing, 20, 21

pigeons, 48

pits, 201 ; number five, 211

Pomeroon, 89, 90

rain, tropical, 120, 121

rainbow, lunar, 58

roaches, wood, 277

Roosevelt, Colonel, 146-150

Roosevelt, Mrs., 147, 148

sandpiper, 47

sargasso weed, animals associated with, 18; fate of, 19; method of grappling, 13.16; origin, 16

scorpions, 152; pseudo, 259

sea-birds, 11

sea, color of, 24; swimming in, 45,46

sea-horses, 18

second-growth, 180

seeds, 75

sharks, harmlessness of, 46

shrimps, 18

skimmers, 97

sloth, name of, 264

snails, 259

snake, 285; green, 72; water constrictor, 72

spiders, 259

spine-tail, 119
Station, Zoological, 141, 153;

Tropical Research, 67

St. Eustatius, 44

St. Kitts, $44-49$

St. Lucia, 54-59; coal-carriers, 55

St. Pierre, 30

St. Thomas, 35-44

Suddie, 70

swifts, Palm, 47, 159; collared, 159

tamarind tree, 38

tanagers, 201, 249, 252

tapir, 90

tarantula, 152

termites, 258; flight, 158; immunity from attack, 233

tinamou, 189; eggs, 189

toads, 161, 213

tody-flycatchers, 127

toucans, 250, 251

trail, Convict, 177-210; Pomeroon, 84-91

trees, silk cotton, 100 ; sentinel, 196 ; wild cinnamon, 241 trogons, 188

Trois Pitons, 58

tropic-bird, 37

trumpet tree, 182

warracabra tiger, 273

wasp, 63, 83

wharf, Dutch, 71

woodhewers, 249, 251

woodpeckers, 249, 25I, 252

worm, inch, 229

wrens, 157,250

Zoological Society, New York, 67 



\section{B Y D OROTHY CA N I E L D}

\section{THE BENT TWIG}

The story of a lovely, opened-eyed, opened-minded American girl. $\$ 1.50$ net.

"The romance holds you, the philosophy grips you, the characters delight you, the humor charms you-one of the most realistic American families ever drawn."-Cleveland Plaindealer.

\section{THE SQUIRREL-CAGE}

An unusual personal and real story of American family life. $\$ 1.50$ net.

"We recall no recent interpretation of American life which has possessed more of dignity and less of shrillness than this."-The Nation.

\section{HILLSBORO PEOPLE}

With occasional Vermont verse by SARAH N. CLEGHORN. $\$ 1.50$ net.

"No writer since Lowell has interpreted the rural Yankee more faithfully."-Review of Revicws.

\section{THE REAL MOTIVE}

Unlike "Hillsboro People," this collection of stories has many backgrounds, but it is unified by the underlying humanity which unites all the characters. $\$ 1.50$ net.

\section{UNDERSTOOD BETSY}

Illustrated by ADA C. Williamson. $\$ 1.30$ net.

"Children will read it eagerly for the story of a very real little girl. Parents will find it worth a whole shelf of books on child training. Teachers will get more than one pointer from its pages, and anyone with a grain of humor can't afford to miss it."-Publishers' Weekly.

HEN R Y HOLT Publishers
A N D COMPAN Y NEw York 
Biographies of men of all countries who have had a definite influence on thought and action in the Nineteenth Century:

Edited by BASIL WILliaMS. Octavo.

With frontispiece. Each, \$2.25 net.

\section{ABRAHAM LINCOLN, \\ By LORD CHARNWOOD}

"The most complete interpretation of Lincoln as yet produced, and presented in such artistic form that it may well become classic."-American Historical Revieru.

\section{HERBERT SPENCER}

\section{By HUGH ELLIOT}

"Rarely, if ever, has the man and his work been set forth so completely and so lucidly. To obtain a clear idea of the Spencerian philosophy is not difficult for the reader who follows Mr. Elliot. A notable contribution to the history of English philosophy."-Boston Transcript.

\section{PORFIRIO DIAZ}

By DAVID HANNAY

"A volume of singular charm and of unrivaled value as an authentic history of Diaz and the Mexico of his day." -New York Tribune.

\section{DELANE OF THE TIMES}

By SIR EDWARD COOK

"Extremely well and sometimes brilliantly written. A miracle of compression and interest, it provides an indispensable appendix to Moneypenny's Disraeli and Morley's Gladstone." - London Daily News.

\section{IN PRESS \\ ABDUL HAMID \\ By SIR EDWIN PEARS \\ LI HUNG CHANG \\ BY J O P BLAND}

\begin{tabular}{lrrr}
\hline HENRY & HOLT & AND & COMPAN \\
Publishers & & NeW York
\end{tabular}




\section{ROBERT F ROS T}

"An authentic original voice in litarature."-The Atlantic Monthly.

\section{MOUNTAIN INTERVAL}

"A remarkable work touched with prophecy and poetic passion."-Brooklyn Eagle.

"A poetic art almost classical in its restraint."-Review of Reviews.

"The same distinguished and distinctive features as its predecessors, with perhaps still finer finish, color, mellowness, delicacy and half-hid humor."-Chicago Herald

\section{NORTH OF BOSTON}

"The poet had the insight to trust the people with the book of people and the people replied 'Man, what is your name?" -New York Evening Sun.

"The first poet for half a century to express New England life completely with a fresh, original and appealing way of his own."-Boston Transcript.

\section{A BOY'S WILL Mr. Frost's First Volume of Poetry}

"We have read every line with that amazement and delight which are too seldom evoked by books of modern verse." The Academy (London):

MOUNTAIN INTERVAL.

NORTH OF BOSTON.

$A B O Y$ 'WILL.
Cloth. \$1.25 net. Cloth. $\$ 1.30$ net. Cloth. $\$ 1.00$ net. 


\section{WR I TERS OF THE DA Y}

Critical estimates of the works of famous authors and accounts of their lives, written while they are yet alive, and done, not by literary hacks, but by fellow-craftsmen of a younger generation distinguished for imaginative work.

Each volume with portrait and bibliography, 75 cents net.

"There is nothing perfunctory about these little volumes. . . All are terse, breezy, comprehensive, authoritative." -New York Times Review.

\section{ANATOLE FRANCE}

By W. L. GEORGE

H. G. WELLS

By J. D. BERESFORD

ARNOLD BENNETT

By F. J. H. DARTON

RUDYARD KIPLING

By JOHN PALMER

HENRY JAMES

By REBECCA WEST

JOSEPH CONRAD

By HUGH WALPOLE

THOMAS HARDY

By HUGH CHILD

JOHN GALSWORTHY

By SHEILA KAYE-SMITH

MRS. HUMPHRY WARD

By STEPHEN GWYNN

HENRY HOLT AND COMPANY

Publishers

NEW YORK 


\section{B Y S I M E O N S T R U N S K Y}

\section{PROFESSOR LATIMER'S PROGRESS}

The "sentimental journey" of a middle-agec" American scholar upon whose soul the war has come down heavily, and who seeks a cure-and an answer -in a walking trip up-State.

"The war has produced no other book like 'Professor Latimer's Progress,' with its sanative masculine blend of deep feeling, fluid intelligence, and heart-easing mirth, its people a joyous company. It is a spiritual adventure, the adventure of the American soul in search of a new foothold in a tottering world. We have so many books of documents, of animus, or argument; what a refreshment to fall in, for once in a way, with a book of that quiet creative humor whose "other name' is wisdom."-The Nation. (Illustrated, \$1.40 net.)

\section{LITTLE JOURNEYS TOWARDS PARIS ( $\left.\begin{array}{l}1914 \\ 1918\end{array}\right)$}

By W. Hohenzollern, translated and adapted for unteutored minds by Simeon Strunsky. 75 cents net.

"If only the Germans could be supplied with translations of this exquisite satire they would die laughing at the grisly joke on themselves. Not only funny, it is a final reductio ad absurdum of the Hun philosophy."-Chicago Tribune.

\section{BELSHAZZAR COURT \\ Or Village Life in New York City}

Graceful essays about the average citizen in his apartment house, in the street, at the theater, the baseball park, with his children, etc. \$I.35 net.

\section{HENRY HOLT AND COMPANY PUBLISHERS \\ NEW YORK}




\section{BOOKS FOR THESE TIMES}

ALSACE-LORRAINE UNDER GERMAN RULE

By Charles Downer Hazen, Professor of History, Columbia University. $\$ 1.30$ net.

\section{EUROPE SINCE 1815 \\ By Charles Downer Hazen}

One of the most widely read books of non-fiction in recent years. With maps. $\$ 4.00$ net.

TOPOGRAPHY AND STRATEGY IN THE WAR

By Douglas W. Johnson, Assistant Professor of Physiography, Columbia University. With 20 maps and numerous half-tones. $\$ 2.00$ net.

\section{THE SOUL OF THE RUSSIAN REVOLUTION By Moissaye J. Olgin}

Mr. Olgin has been, since 1900 , in the very throes of the new Russia. Illustrated. $\$ 2.75$ net.

\section{OUR DEMOCRACY, ITS ORIGINS AND ITS TASKS}

By James H. Tufts, Professor in the University of Chicago.

Not so much a consideration of the machinery of government as a study of those principles and ideas the machinery is meant to serve. $\$ 1.50$ net.

\section{THE STAKES OF DIPLOMACY}

By Walter Lippman. Cloth, $\$ 1.40$ net; paper, 60 cents net.

HENRY HOLT AND COMPANY PUBLISHERS 
The Third Edition, Revised and Enlarged, of

\section{THE HOME BOOK OF VERSE \\ COMPILED BY \\ BURTON E. STEVENSON}

has been revised from end to end-590 poems have been added, pages renumbered, author, title, and first line indices, and the biographical matter corrected, etc., etc.

The hundreds of letters from readers and poets suggesting additions or corrections as well as the columns of reviews of the first edition have been considered. Poets who were chary of lending their support to an unknown venture have now generously permitted the use of their work.

This edition includes the "new" poets such as MASEfield, Chesterton, Frost, Rupert Brooke, de la Mare, Ralph Hodgson, etc.

"A collection so complete and distinguished that it is difficult to find any other approaching it sufficiently for comparison."-New York Times Book Review on the first edition.

\section{India Paper, 4,096 pages}

Cloth, one volume, $\$ 10.00$ net.

Cloth, two volumes, $\$ 12.50$ net.

Half Morocco, one volume, $\$ 14.00$ net.

Half Morocco, two volumes, $\$ 25.00$ net.

H E N R H OL T A N C O M P A Y PUBLISHERS 


\section{J E A N - C H R IS T O P H E By ROMAIN ROLLAND}

Translated from the French by GILBert CANNAN. In three volumes, each $\$ 1.75$ net.

This great trilogy, the life story of a musician, at first the sensation of musical circles in Paris, has come to be one of the most discussed books among literary circles in France, England and America.

Each volume of the American edition has its own individual interest, can be understood without the other, and comes to a definite conclusion.

The three volumes with the titles of the French volumes included are:

JEAN-CHRISTOPHE

DAWN-MORNING-YOUTH-REVOLT

\section{JEAN-CHRISTOPHE IN PARIS}

The Market Place-Antoinette-The House

\section{JEAN-CHRISTOPHE: JOURNEY'S END}

Love and Friendship-The Burning Bush-The New DAWN

\section{Some Noteworthy Comments}

"'Hats off, gentlemen-a genius.' . One may mention 'Jean-Chris. tophe' in the same breath with. Balzac's 'Lost Illusions'; it is as big as that. . It is moderate praise to call it with Edmund Gosse the noblest work of fiction of the twentieth century.' A book as big, as elemental, as original as though the art of fiction began today. We have nothing comparable in English literature. "Springfield Republican.

"If a man wishes to understand those devious currents which make up the great, changing sea of modern life, there is hardly a single book more illustrative, more informing and more inspiring."-Current Opinion.

"Must rank as one of the very few important works of fiction of the last decade. A vital compelling work. We who love it feel that it will live."-Independent.

"The most momentous novel that has come to us from France, or from any other European country, in a decade." - Boston Transcript.

A 32-page booklet about Romain Rolland and Jean-Christophe, with portraits and complete reviews, on request.

HENRY
RUBLISHERS









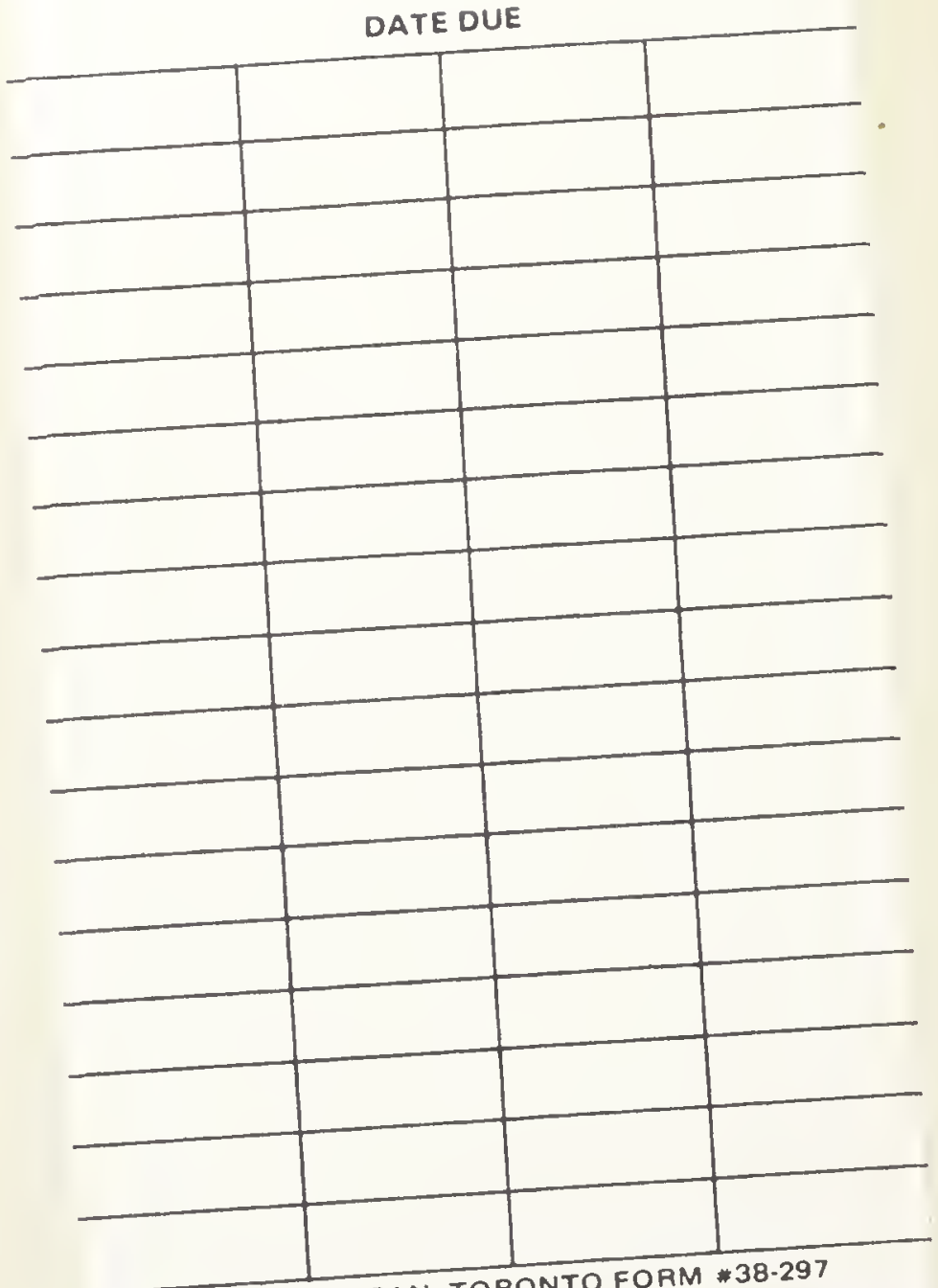

CARR MCLEAN, TORONTO FOAM *38-297 


\section{QH 125 B4 1919 \\ Beebe, Charles William, 1 \\ ungle peace / by William Beeb 010101000

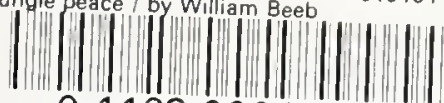 \\ 0116300047598 \\ TRENT UNIVERSITY}

$$
\begin{aligned}
& \text { QH125.B4 } 1919 \\
& \text { Jungle peace }
\end{aligned}
$$

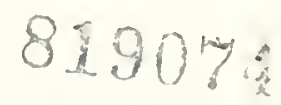




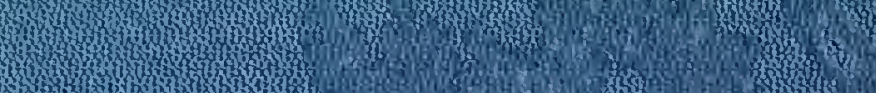

B.m.t.m.

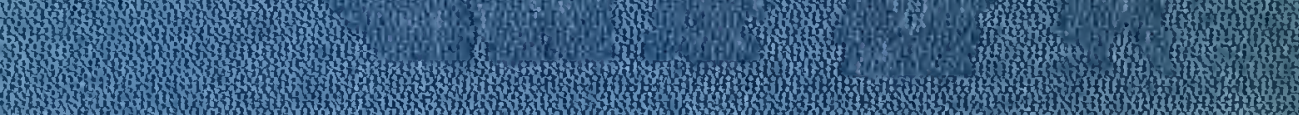

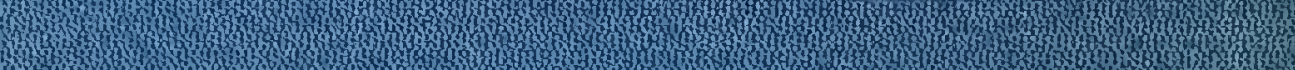

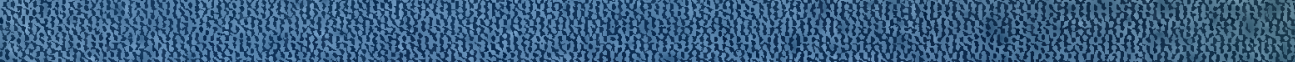
H.

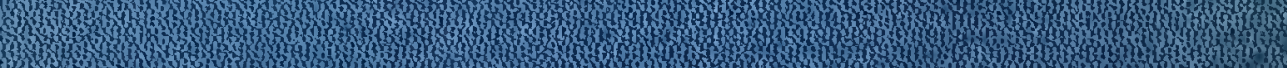

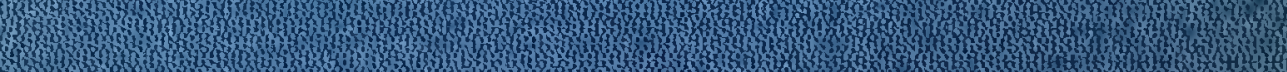
1.6.

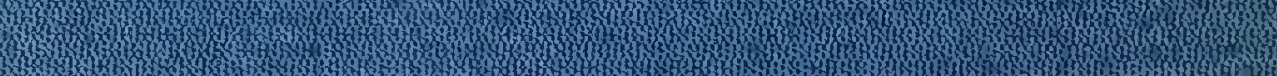
37. W.

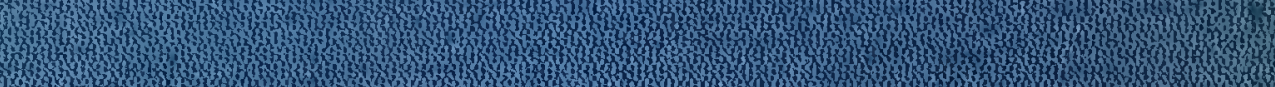
H. H.

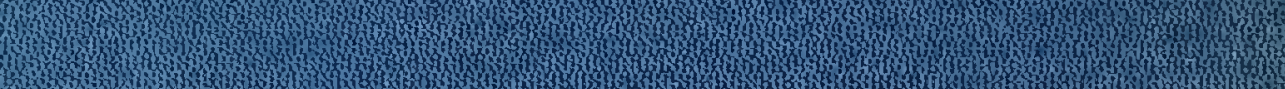

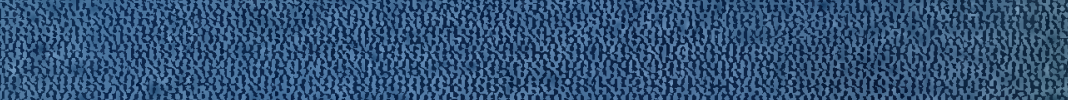

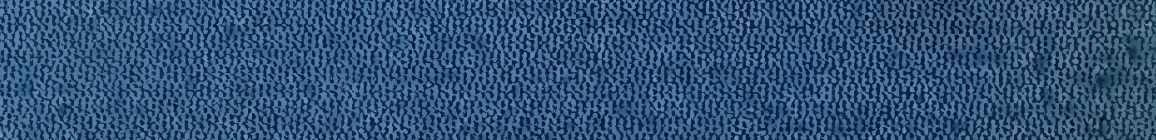
A.t. 